\title{
AS ORIGENS DA ROTA MARÍTIMA: MARES, BARCOS E HOMENS1
}

Pascal Arnaud 2

No século IV d.C. o compilador Marciano de Heráclea (Per. Mar. Ext., $1.2=$ Müller1855, 517, sq.) opunha nestes termos a diferença entre a rota terrestre e a rota marítima:

De fato, uma navegação no mar não se desenvolve de acordo com uma sequência de locais de localização consensual (topoï homologèménoï), como quando se viaja em terra emprestando uma via pública. Para o propósito da apresentação, vamos supor um golfo que segue a costa em um perímetro de cem estádios. Se alguém sair por mar perto da costa, ele encontrará um número de estádios substancialmente menor do que aquele que será obtido por quem anda por terra. No entanto, não será muito longe do valor exato. Aquele que navegar mais longe da costa encontrará um número de estádios menor do que aquele que será encontrado ao longo da costa mais próxima, e assim por diante, sempre que o arco descrito pela travessia for mais curto.

Em efeito, uma rota marítima não é traçada, não é limitada e não possui postes indicadores. Mesmo no caso considerado aqui por Marciano, de uma rota entre dois pontos terrestres teoricamente conhecidos (os dois cabos limitando um golfo), aquele que é responsável pelo navio possui de fato a escolha de um número infinito de rotas pouco diferentes umas das outras, mas que em todo estado de caso, não procedem de uma rota préestabelecida, mas de uma decisão de rota baseada na combinação de parâmetros variáveis, que podem ser tanto condições específicas para um dia específico, os imperativos ligados a uma carga ou a uma prática comercial, bem como à rotina.

Quanto mais distante da costa, mais ampla é a margem de escolha e mais ampla a gama de possibilidades, à medida que nossa percepção da materialidade da rota se torna obscurecida. No entanto, a reconstituição de rotas marítimas é uma questão essencial na história do antigo comércio

\footnotetext{
${ }^{1}$ Este texto foi publicado originalmente como capítulo do livro Les routes de la navigation antique - Itinéraires en Méditerranée (Capítulo I), de autoria de Pascal Arnaud (Paris: Editions Errance, 2005); foi traduzido com a anuência do autor e da editora. Tradução de Felipe Alberto Dantas - felipealbertodantas@hotmail.com

2 Professor emérito de História do mundo romano do Departamento de História da Universidade de Lyon II - arnaudp2003@yahoo.fr
}

Heródoto, Unifesp, Guarulhos, v.4, n.1 - 2019.1. p. 327-394

DOI: 10.34024/herodoto.2019.v4.10124 
marítimo. É a própria reconstituição do espaço-tempo do mundo mediterrâneo grego e romano.

\section{Rotas e fluxos}

Uma questão de fundo para qualquer um que se interesse pela navegação e pelo comércio antigos: por onde os navios passavam realmente, quando transportavam, a partir de um ponto $\mathrm{A}$, um objeto produzido em um ponto $B$ para um porto $C$, a partir do qual ele era vendido para um local de consumo D, sabendo que B e D são geralmente as únicas certezas? Uma série de questões relacionadas emergem rapidamente: existiram itinerários de ida e de retorno distintos (Janni, 1998: 44-45)? Qual era o grau de segmentação dos percursos? Qual poderia ser o tempo normal dos trajetos? Como, sem mapa, bússola ou astrolábio, levava-se um navio à sua destinação?

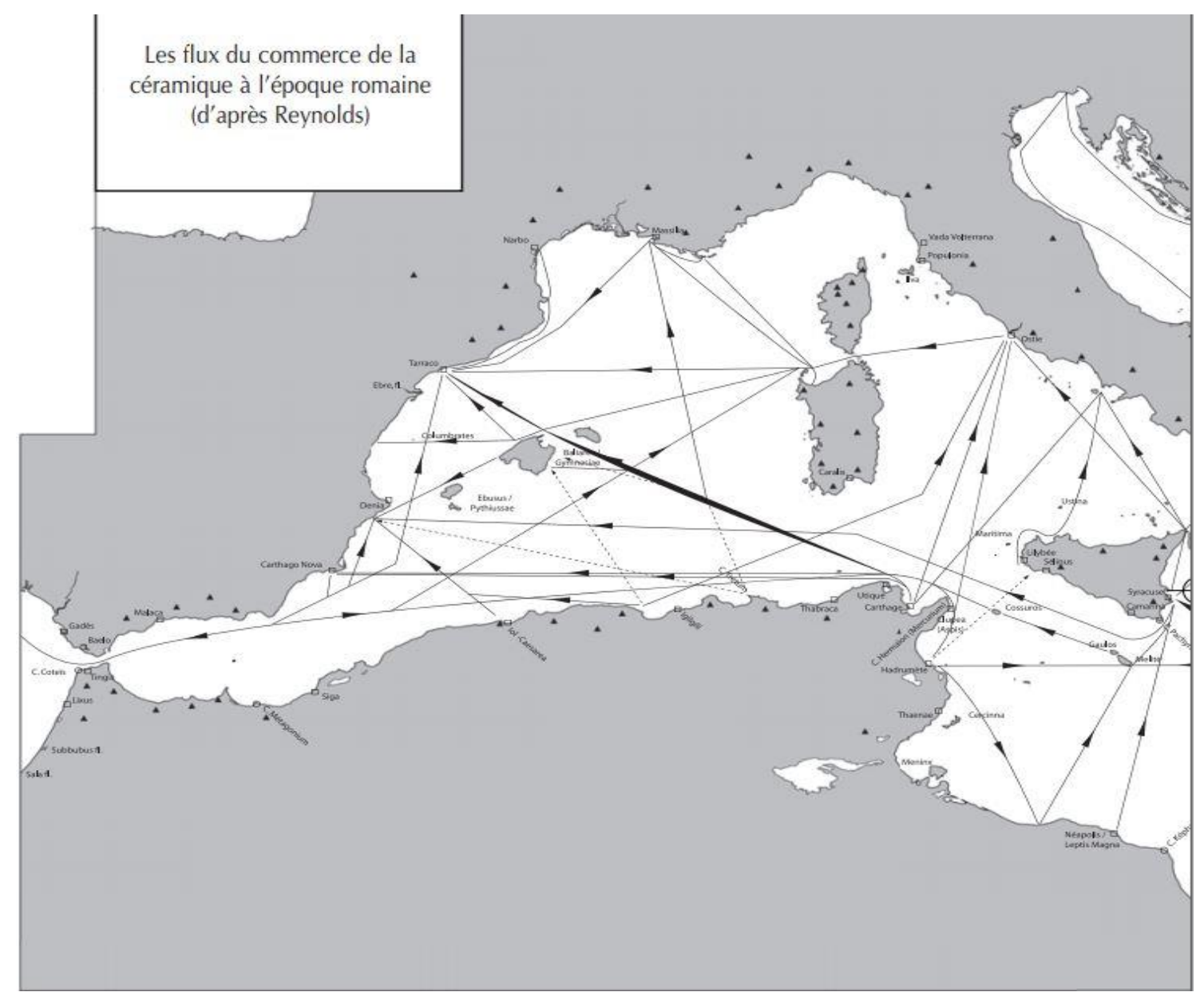

Heródoto, Unifesp, Guarulhos, v.4, n.1 - 2019.1. p. 327-394

DOI: 10.34024/herodoto.2019.v4.10124 


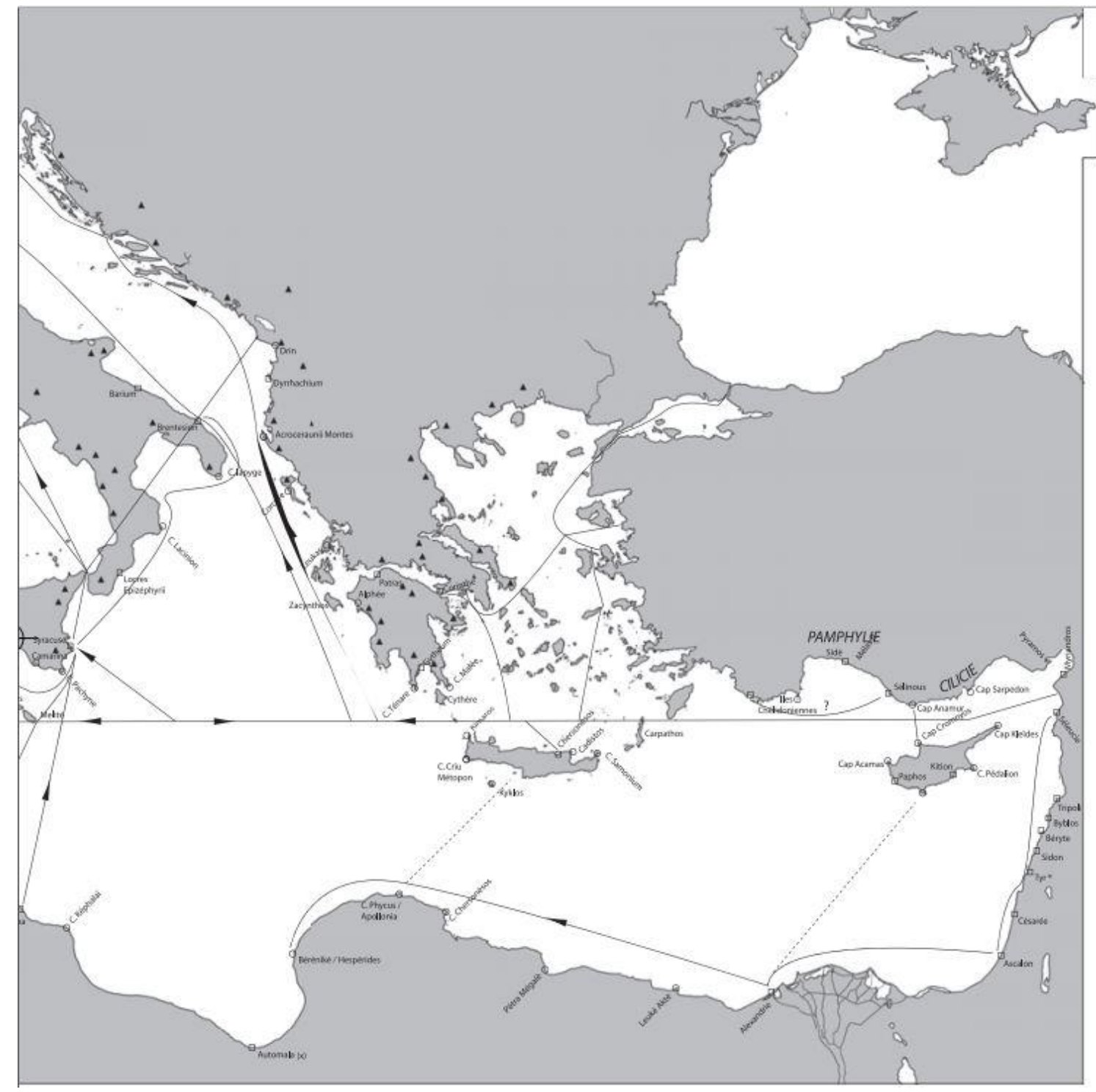

Fig. 1. Esse mapa não ilustra na realidade rotas, em estrito senso, mas os grandes fluxos comerciais da cerâmica antiga, em suas diversas formas (ânforas, louças, azulejos, objetos).

Irritantes questões as quais temos dificuldades de responder, com base na documentação clássica, desde que resistamos à tentação de limitar a navegação antiga a dois esquemas opostos também muito redutores: aquele que assimilaria a rota de navegação a uma linha reta entre um ponto de partida e um ponto de destino, e o que limitaria a navegação antiga à cabotagem. Porém, essas duas tendências continuam a organizar as reconstituições da maior parte da erudição moderna. É por isso que a realidade da navegação nos escapa, desde que saiamos de histórias de viagens calamitosas ou dos dados da arquitetura naval. As viagens normais, em regra, não são contadas, ou há apenas a menção de um tempo de percurso, total ou parcial. Quanto ao nosso conhecimento da arquitetura naval, com a exceção de alguns destroços de naufrágio de grandes dimensões, ele é geralmente é limitado a unidades muito pequenas, das

Heródoto, Unifesp, Guarulhos, v.4, n.1 - 2019.1. p. 327-394

DOI: $10.34024 /$ herodoto.2019.v4.10124 
quais raramente há mais do que o fundo do casco. Afundadas em águas rasas, mais perto da costa, seja por ocasião de um itinerário costeiro ou no final de uma travessia, ou ainda à saída de uma longa deriva, elas envolvem normalmente pequenas embarcações engajadas em um comércio de redistribuição e raramente podem ser solicitadas para revelar de modo claro rotas de grande distância.

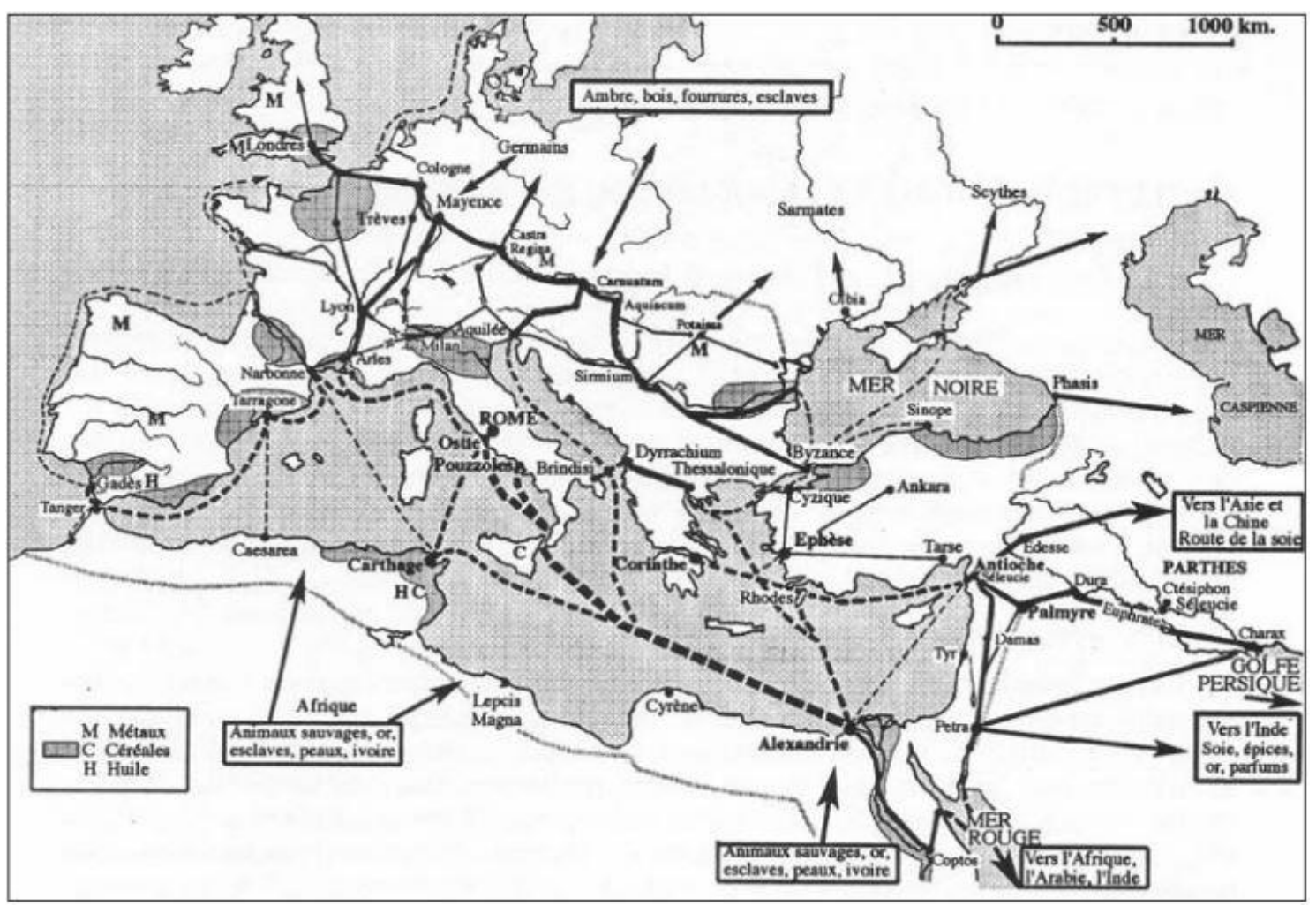

Fig. 2. Os grandes fluxos de mercadorias do Mediterrâneo romano, a partir de Westermann, Y. Perrin et TH. Bauzou 1997. Notaremos a representação, herdeira de J. Rougé, de rotas com traçados próximos do itinerário mais direto, sem jamais se confundir com ele. Esse modo de representação tende a dar crédito a uma leitura marítima moderna das rotas de navegação;

É realmente muito difícil de inferir a partir do carregamento dos destroços, em detalhe, a rota seguida pelo navio até ao seu naufrágio ${ }^{3}$. Uma carga múltipla não requer necessariamente uma multiplicidade de escalas comerciais identificáveis à origem de cada um dos produtos transportados. Foi o geralmente postulado para a última viagem dos destroços do Kyrénia. Esta unidade, cujas dimensões mal excedem as de uma simples e confortável embarcação de recreio de hoje, tinha uma cabine na popa e um vagão na frente, e afundou em Chipre, no final do século IV a.C., provavelmente como resultado de um ato de pirataria. Sua carga incluía 404 ânforas, incluindo 343 ânforas Rhodianas, 29 rodas de grão dispostas

3 Para a contribuição e estudo de navios naufragados (natureza, distribuições, tonelagem, de origem e de datação), ver Gianfrotta-Pomey 1980 e Pomey Rieth-2005.

Heródoto, Unifesp, Guarulhos, v.4, n.1 - 2019.1. p. 327-394

DOI: 10.34024/herodoto.2019.v4.10124 
em 3 fileiras e 10.000 amêndoas (inicialmente armazenadas em sacos), e serviu de base para a reconstituição de seu itinerário desde o Pireu, pelas Cíclades. Se as conclusões tiradas a partir do carregamento são exatas, elas ilustram as práticas comerciais próprias a um pequeno cabotador. Inversamente, o naufrágio do Cabrera III dá o exemplo de uma carga de proveniência variada, que não pode ser utilizado para definir a rota do navio, embora as origens das várias ânforas que compõem esta carga mista sejam bem conhecidas. De fato, o carregamento foi organizado em uma única operação e os vários tipos de ânforas foram dispostos em posições que se adaptavam à sua forma e peso: na periferia, contra o casco, para uns, no centro para outros. Nestas condições, é impossível presumir, em princípio, uma relação direta entre os portos de partida e os portos de chegada das mercadorias (Pomey, 1997: 121-127 e 146-159 sobre o comércio de redistribuição).

As capacidades técnicas das embarcações, como veremos, não nos dizem mais, mas é agora provável que, na sua grande variedade, cada um dos tipos de embarcações tenha sido adaptado às exigências de um programa e/ou de uma bacia de navegação, e há uma boa probabilidade de que as embarcações destinadas à navegação ao largo, em sua maioria, eram capazes de realizar - ao preço de manobras, gestos e dificuldades por vezes específicas, tendo em conta as suas particularidades e evoluções tecnológicas - a totalidade de evoluções de que um navio de aparelhamento quadrado era capaz até antes de meados do século XVIII.

Existe, de fato, uma certa confusão em torno da noção de rota marítima, que não distinguimos suficientemente do fluxo marítimo. A rota marítima é a rota real entre $\mathrm{A}$ e $\mathrm{B}$, quando o fluxo se refere à constatação de que um produto considerado como tendo sido produzido num ponto A foi transportado até um ponto B. As condições naturais de navegação nunca impediram os fluxos, enquanto a economia ou a política se impunham. Por outro lado, elas impunham um número limitado de rotas determinadas e favoreciam certos itinerários. A maioria dos mapas comerciais estabelece relações diretas, como que tiradas à régua do mapa, por vezes ao ponto de evocar uma "ponte aérea" entre o local de produção e o local de consumo de uma série coerente de objetos. Certamente, o produto concernido, passou do ponto A para o ponto B, e assim um fluxo comercial pode ser determinado. No entanto, deve ter-se o cuidado de que o fluxo comercial assim identificado nunca seja confundido com a rota realmente realizada por um navio. Se os fluxos comerciais podem, e devem fornecer evidências para estabelecer hipóteses de rotas, eles não podem sozinhos revelá-las.

A evolução do pensamento de R. Duncan-Jones é notável a este respeito. Em um primeiro livro (1974: 366-369), ele tentou, com base nos dados do Heródoto, Unifesp, Guarulhos, v.4, n.1 - 2019.1. p. 327-394

DOI: 10.34024/herodoto.2019.v4.10124 
édito do Máximum de Diocleciano, um estudo comparativo dos custos dos transportes por vias fluviais e marítimas. Para fazer isso, ele necessitava de duas unidades comuns: uma para o objeto transportado, a outra para a distância, a fim de alcançar uma comparação dos custos por quilometro do transporte do mesmo objeto. Para o produto de referência, um problema se impunha: o do valor em capacidade do modius kastrensis (o "alqueire campestre") de trigo, que era desconhecido, comparado com o modius (alqueire) itálico. Pela distância, ele se limitou a procurar a linha mais direta.

Porém, poderíamos nos surpreender que, quando ele encontrasse a chave para o valor do modius kastrensis, que teria lhe permitido especificar sua grade (Duncan-Jones, 1996; Arnaud, 2001), ele não a usou para atualizar sua tabela de custos. As teses desenvolvidas em seu destacado trabalho, dedicado à estrutura e à escala na economia romana mostram que, de fato, ele havia admitido, a partir de então, que uma abordagem estritamente quilométrica não fazia sentido e que a fragmentação dos percursos, à qual ele foi o primeiro a colocar em princípio (Duncan-Jones, 1990: 17), impunha levar em conta a duração global de um percurso e, portanto, não mais um itinerário teórico, e sim um itinerário prático e real.

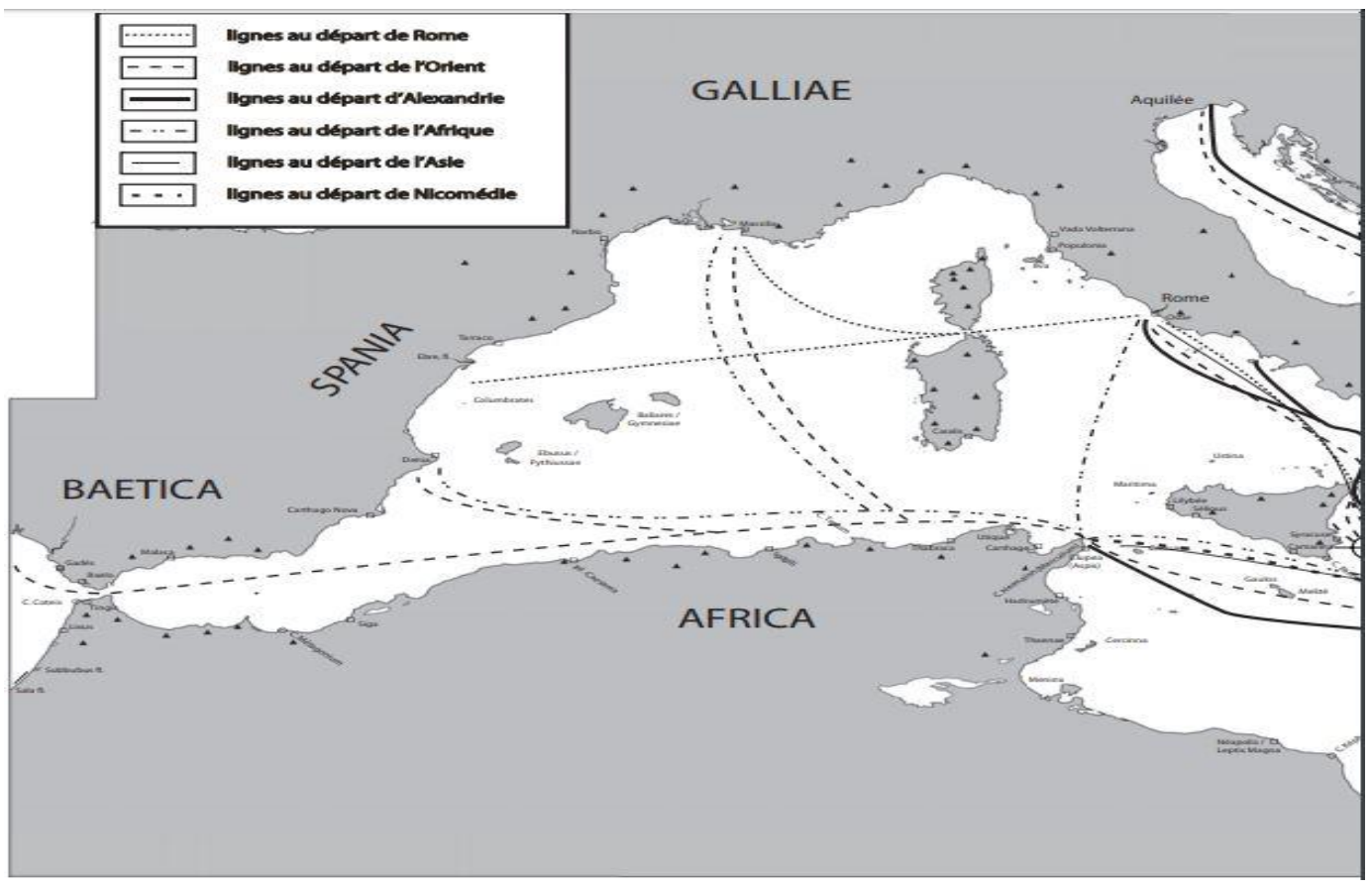

Heródoto, Unifesp, Guarulhos, v.4, n.1 - 2019.1. p. 327-394

DOI: 10.34024/herodoto.2019.v4.10124 


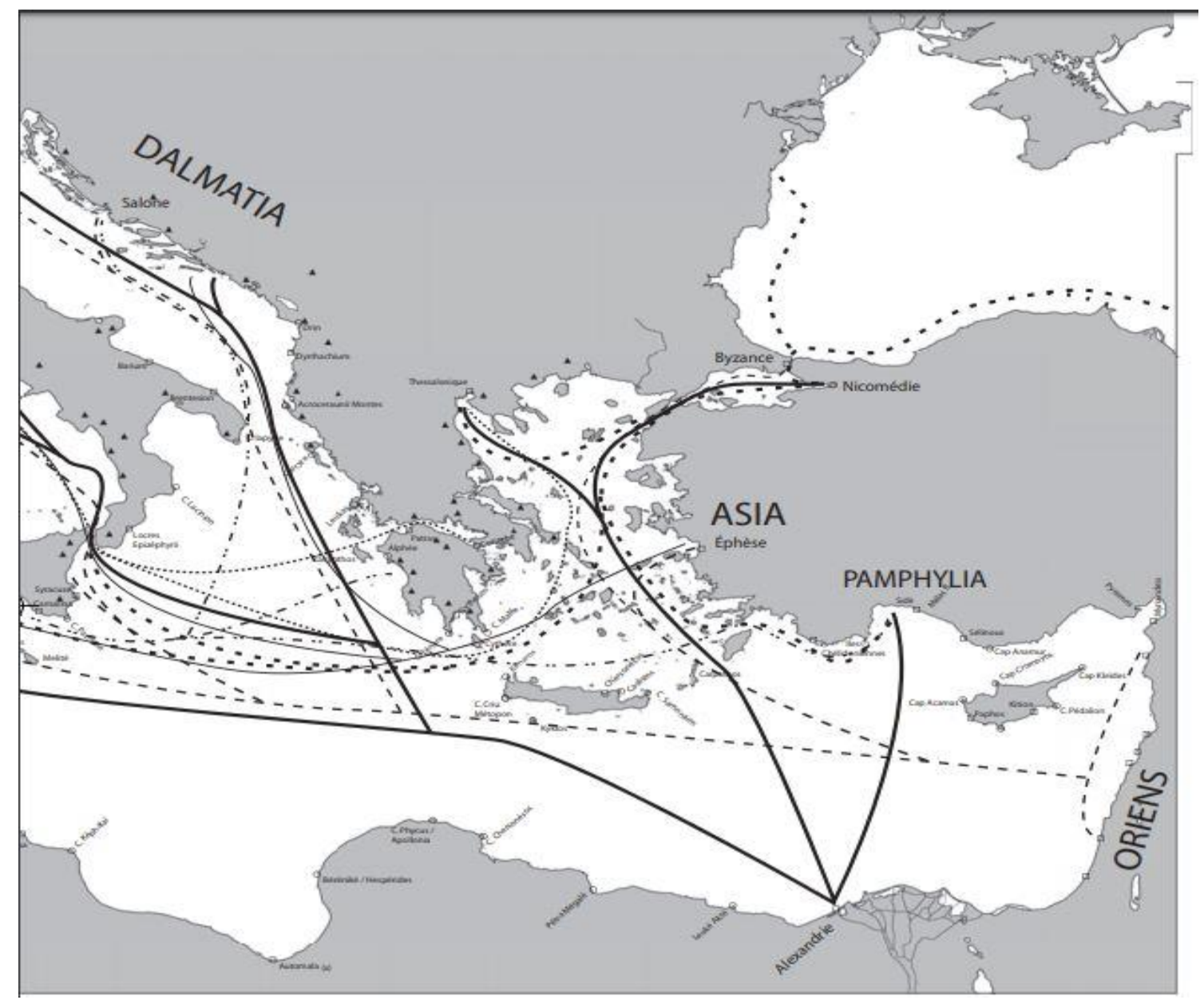

Fig. 3. As rotas do Mediterrâneo segundo os dados do Édito de Diocleciano (301), depreendidas de J. Rougé (P.A.). Esse édito, que fixa o preço Maximun de um certo número de produtos e serviços, fixa o custo unitário do transporte de um "alqueire campestre" de trigo, sobre um certo número de relações à grande distância reportados nesse mapa. Somente os pontos de partida e chegada são dados no texto do Édito. O traçado da rota é uma proposição de J. Rougé que tende a dar crédito a uma percepção bem direta e marítima da rota.

O itinerário selecionado em 1974 para estabelecer o custo marítimo de referência era exemplar: aquele de Roma à Alexandria, pelo qual ele supunha a hipótese de uma viagem em linha reta. Esse itinerário é admissível no sentido de retorno de navios de transporte de provisões vazios, em direção à Alexandria. Mas o conjunto da documentação disponível sugere que as duas principais rotas utilizadas para a ida eram mais indiretas, de acordo com as condicionantes inerentes ao regime dos ventos predominantes, e que elas passavam seja pela Cirenaica e Sicília, seja pelo Chipre, pela Lícia, Rhodes e pelo sul de Creta ${ }^{4}$, segundo um itinerário que continua bastante frequentado até o fim da navegação à vela.

${ }^{4} \mathrm{~A}$ rota alternativa, através da Cirenaica (que poderia facilmente se ramificar rumo à Creta e reintegrar-se a uma rota clássica) e da costa do Norte da África para a Sicília, foi Heródoto, Unifesp, Guarulhos, v.4, n.1 - 2019.1. p. 327-394 
A resistência da imagem intelectual da rota direta é surpreendente: depois de ter demonstrado claramente a existência desses dois itinerários, J. Rougé (1966: 88-89) desenhava um mapa das principais rotas de navegação que excluía esses dois caminhos, desviados, em proveito de uma representação mais direta da rota de Alexandria a Roma, pelos Cárpatos (Scarpanto), quase que impensável para qualquer estação no sentido Alexandria-Roma.

Em detalhe, sempre que uma incerteza persiste, a tendência tem sido estabelecer uma linha direta entre a última escala e o primeiro destino conhecido: um navio parou em Cyrene, ou em Parætonium (Hieron., Vit Hilar.: 35-36) em direção à Sicília? Considera-se então ter cruzado "diretamente" até a Sicília. Mas qual é o significado de "diretamente"? Deveríamos ouvir "Em linha reta" ou "sem outra parada em outro porto"? É isso que teremos que estabelecer.

\section{As condições naturais}

As rotas marítimas que tentaremos destacar, e cuja lista certamente não será exaustiva, dependem em grande medida das condições naturais, que estabelecem um quadro restritivo, mas não a ponto de se estabelecer em restrição absoluta, e se as condições naturais e as soluções técnicas constituem os dados básicos da rota, só permitem definir um número limitado de soluções razoáveis. A rota é sempre uma escolha, muitas vezes óbvia, mas não tento quanto podemos imaginar. Ela incorpora restrições naturais conhecidas (o tempo que faz) e calculadas (o tempo que se pode razoavelmente pensar que vai fazer) com base em uma profunda compreensão, tanto do padrão meteorológico para a temporada do percurso, da área ou áreas em que está prestes a navegar, e da própria rota, que condiciona a lista dessas áreas. Com exceção de alguns casos excepcionais, todos duvidosos, a imagem odisseiana da navegação antiga, mesmo aquela do período arcaico, empregada por um marinheiro aventureiro e explorador, deve ser substituída em favor da observação das rotinas marítimas baseadas na integração, pela aprendizagem, de conhecimentos multisseculares acumulados por gerações de navegadores

inferida por Casson (1971, 297-298) e Rouge (1966, 86-99) a partir de uma carta de um recruta de Alexandria confiada a uma pessoa de Cirene que conheceu durante a sua viagem a Roma (Pap. Mich.490, II e século). Esta linha, normal no século XI, por razões políticas óbvias, desenvolve-se no verão contra ventos e correntes, e é com razão que Rouge o refere a um período particular do ano: o soldado autor desta carta, de fato, chegou ao seu destino, Pouzzoles, bem cedo na estação, em 20 de maio. Pryor (1992, 6-7, $90,99)$ e McCormick $(2001,503)$ consideram a rota pela Lícia como o itinerário normal.

Heródoto, Unifesp, Guarulhos, v.4, n.1 - 2019.1. p. 327-394

DOI: 10.34024/herodoto.2019.v4.10124 
e transmitidos pela aprendizagem de marinheiro a marinheiro, piloto a piloto.

No entanto, no caso de fenómenos meteorológicos fora do controle dos trabalhadores do mar, esta escolha envolve uma parte de aposta. É bem verdadeira que uma das maiores figuras da tópica literária, durante toda Antiguidade, é a que fez da navegação marítima o lugar por excelência para o exercício dos caprichos da Fortuna. Se a rota escolhida for o resultado de normas ambientais conhecidas (Morton, 2001) (ventos predominantes, efeitos sobre estado do mar, natureza e posição das zonas costeiras sob o vento), mas também das limitações técnicas e do comportamento humano, este últimos in fini que determinam a escolha. $\mathrm{O}$ caminho realmente seguido é, em primeiro lugar, o feito dos caprichos do clima, mas é igualmente o resultado da adaptabilidade dos marinheiros a bordo a estas alterações, que pressupõem o conhecimento, em função da posição estimada do navio, das consequências, em termos de rota, das decisões tomadas para fazer face à emergência inesperada de condições desfavoráveis. $\mathrm{O}$ homem permanece mestre em todos os aspectos do seu destino: não são as condições naturais, mas o conhecimento delas, como também não são as limitações técnicas, mas o interesse, o conforto ou o prazer de manter esta ou aquela manobra em vez de outra, que determina a escolha de uma rota, e cabe sempre ao que comanda, como último recurso, escolher, numa situação específica, uma determinada rota. Que elas sejam naturais ou técnicas, as restrições definem a não ser um quadro geral, ao interior do qual se inscrevem sempre várias possibilidades que abrem o caminho a estratégias diversificadas. Em uma palavra, quando a rota direta é teoricamente possível, ela pode ser descartada em favor de outra considerada mais vantajosa por todo um conjunto de razões. Finalmente, quando falamos de navegação antiga em geral, e de rotas, em particular, seria bom abrir mão de se obliterar com a ideia de uma performance técnica que tende a assimilar os navegadores a praticantes de regatas, para tentar em contrapartida, raciocinar de acordo com as preocupações, de início comerciais do comerciantes e proprietários de embarcações, para quem o mar era, antes de qualquer outra coisa, uma fonte de lucro.

As condições naturais de navegação são, de fato, determinadas por três elementos:

- Os ventos;

- As correntes;

- A natureza da costa.

Heródoto, Unifesp, Guarulhos, v.4, n.1 - 2019.1. p. 327-394

DOI: 10.34024/herodoto.2019.v4.10124 
Poderíamos adicionar a visibilidade, em sentido amplo, que depende de fatores meteorológicos, mas também topográficos: pelo efeito da curvatura terrestre, em tempo claro, podemos ver as montanhas antes das costas.

No essencial, elas constituem dados intangíveis, com a notável exceção das linhas costeiras, cuja mobilidade é hoje objeto de cada vez mais trabalhos. No entanto, se excetuarmos os grandes episódios aluviais, como aqueles que, na embocadura do Meandro cobriram o Golfo de Latmos, os que assorearam Éfeso ou que, no sul da Gália, obstruíram o vale inferior de Argens por vários quilômetros, desde o quinto século a.C., fora as variações locais por vezes importantes, relacionadas, em particular, à atividade telúrica, as condições naturais podem ter modificado alguns desembarques, mas não parece não ter perturbado radicalmente as condições comuns de navegação ao longo de uma costa determinada. É notável que as costas de má reputação na Antiguidade são as que geralmente permaneceram com a mesma fama, pelas mesmas razões. Não subestimamos a importância da evolução das fácies costeiras, essencial para a escrita da história dos sistemas portuários, sem esconder que sua contribuição para a história das rotas de navegação é muito mais modesta, mesmo que não seja nula.

Os principais fenômenos que governam o movimento do navio, os ventos e as correntes, são estatisticamente muito mais estáveis, o que obviamente não exclui a possibilidade de existência de fases mais ou menos recorrentes da desordem climática, capazes contradizer todas as estatísticas, numa escala que raramente excede a de uma estação. Então, se nós raciocinamos em termos de permanência estatística, sabemos que os regimes de vento são definidos pelos sistemas orográficos que determinam a direção dos ventos e, em certa medida, sua potência, pelo contraste térmico com o mar. Quanto às correntes, elas são determinadas por três fatores: a rotação do Terra, os efeitos de maré e os ventos, todos parâmetros relativamente estáveis.

São essas permanências que integram os marinheiros e definem as normas estatísticas sobre as quais eles baseiam suas escolhas de rotas. Poderíamos resumir assim sua abordagem: "em tais condições, a experiência coletiva mostra que a melhor maneira de ir de onde estou para onde eu vou é passar por aqui ao invés de por lá". Apesar da inexistência de previsão do tempo séria, até o final da Segunda Guerra Mundial, essa abordagem não foi tão globalmente tomada como padrão nos mares mais familiares, onde um número bastante limitado de grandes acidentes meteorológicos maiores tem sido geralmente considerado como os provedores de uma maioria dos naufrágios. 


\section{Os ventos}

Os ventos tiveram uma influência muito mais decisiva na navegação do que as correntes: na ausência de remos, eles são a força propulsora do barco. A análise de seu regime, mostra, em geral, uma diferença bem nítida entre as estações do inverno e verão. Ela se liga tão às brisas térmicas quanto aos ventos estabelecidos, dos quais a força e direção, e também a regularidade, mudam geralmente de uma estação à outra, ao longo do ano. Estas variações sazonais são tão essenciais neste ponto, que fundaram a determinação empírica, e em consequência legal, de dois períodos:

- Um de mar aberto, que não define uma autorização legal para navegar, mas uma norma suscetível de implicações em termos de tributação ou de avaliação do risco (e, por conseguinte, de fixação de preços). Os Antigos dão dois calendários (Rougé, 1975: 24):

- estreito: de 27 de maio a 14 de setembro, ou seja, uma época de três meses e meio correspondente ao óptimo climático de Verão, e interrompido antes das perturbações climáticas habituais do equinócio outonal;

- largo: de 10 de março a 11 de novembro, época de oito meses, aparentemente mais consentânea com a realidade da navegação, o que exclui as fases de invernais, em geral, mais rigorosas e caracterizadas por tendências extremas, mas inclui os equinócios, tradicionalmente turbulentos em todos os mares ocidentais.

- O outro de mar fechado, entre estes dois períodos; o que não deve ser visto como um período de parada absoluta da navegação.

Existem igualmente normas intermédias, válidas para determinada região. Em 380, um édito publicado em Trier fixa para as frotas de provisões de víveres anuais da África uma temporada de navegação entre 13 de abril e 15 de outubro. Esses calendários parecem definir, para todas as zonas, o período de tráfego mais importante, como ainda era o caso no século XII (Udovitch, 1978: 531-532). Todos os estudos realizados até essa data, tanto para Antiguidade (Rougé, 1952; Rougé, 1966: 32-33; Casson, 1971: 270-273), quanto para a Alta Idade Média (Mc Cormick, 2001: 450-468) e para a Baixa Idade Média (Petti-Balbi, 1996: 279) mostram, de fato, um declínio invernal nos movimentos, mas asseguradamente não a sua interrupção. Mesmo os navios que invernam tendem a fazê-lo o mais longe possível sobre uma rota em curso, deixando para trás de si a parte principal da travessia, com o fim de poder completar a rotação no menor tempo possível. Tal é o caso 
do navio que Paulo e seus companheiros encontram invernando em Malta e que provavelmente parte no final de fevereiro para Pozzuoli 5 .

Não seria questão de fazer uma apresentação estatística exaustiva do regime eólico para todas as bacias abrangidas por este estudo e, em cada uma delas, para cada um dos períodos de navegação em causa. Esta questão será abordada no início da apresentação de cada área de navegação, na segunda parte deste livro. Vamos nos limitar aqui a um esboço de apresentação sobre os desafios para a navegação, em termos gerais, dos dois principais regimes eólicos: os ventos estabelecidos e as brisas térmicas.

\section{Ventos dominantes e navegação em mar aberto}

Numa passagem de sua Geografia, onde tentava pôr em relevo as imensas qualidades da Espanha Meridional, Estrabão (3.2.5, C 143-144) exprimia nesses termos as vantagens naturais às quais se ligavam às condições da navegação comercial, em ilustração, a seus olhos, do progresso (Arnaud 2004):

Todo o comércio de longa distância (emporia) é dirigido (da Turdânia) para a Itália e para Roma, porque goza de boas condições de navegação até as Colunas (de Hércules) [144], com exceção de algumas dificuldades nas zonas do Estreito e naquela de mar aberto que está no Nosso Mar. As rotas de navegação desenvolvem-se num clima calmo, especialmente para aqueles que praticam a navegação de alto mar: porque é lá que ela é útil para navios de comércio (emporoïs olkasin). Os ventos que prevalecem no alto mar também são regulares. Posidônio (F 46) diz que observou um fenômeno singular, durante sua aparelhagem na Ibéria em direção ao alto mar: os ventos do Eurus (leste quartosudeste) estavam soprando, neste mar, até o Golfo da Sardenha, no regime etesiano. Por essa razão, ele teria levado três meses para reganhar, com grande dificuldade, a Itália, depois de ter sido desviado para o lado da Gymnasia (Ilhas Baleares), para a Sardenha, e até mesmo para áreas da Líbia (Norte da África), opostas a essas regiões.

É caracterizado assim o quadro que, do seu ponto de vista, definia as condições otimizadas para a prática do comércio de longa distância, em navios de carga propelidos à vela: ventos estabelecidos em alto mar (e, portanto, distintos da brisa costeira), soprando sem excesso e com regularidade. A segunda parte do texto, relativa aos infortúnios de Posidonius, desviado durante três meses por ventos contrários, permite especificar um outro dado de evidência: os ventos devem ser orientados

\footnotetext{
5 Para a reabilitação do valor documental dessa narrativa (Act. Apost., 27,1-28,13) Rougé 167, assim como a tradução e comentário de P. Pomey e A. Tchernia em Pomey 1997.
}

Heródoto, Unifesp, Guarulhos, v.4, n.1 - 2019.1. p. 327-394

DOI: 10.34024/herodoto.2019.v4.10124 
favoravelmente. Esse texto, portanto, parece resumir os parâmetros que definiam, aos olhos dos antigos, o coeficiente de navegabilidade específico a um regime de vento determinado.

Esse texto enfatiza uma exigência fundamental da navegação marítima: a de ter ventos estabelecidos, de acordo com orientações conhecidas ou previsíveis, por uma duração equivalente a duração esperada da travessia. $\mathrm{Na}$ ausência de previsões detalhadas, saber que tal vento era normalmente estabelecido, em tal distância, por um período mínimo determinado era evidentemente um bem valioso. Além disso, os ventos variáveis ou instáveis tornam muito aleatória a navegação sem instrumentos, enquanto um vento direcional conhecido e bem estabelecido conduz o navio à destinação tão certamente quanto uma bússola; o inesperado refrescamento do vento muitas vezes desorienta os navios, e a calmaria (bonança ou "petoles") no alto mar, muitas vezes é anunciadora de uma mudança orientação brutal do vento, provando tanto o moral das tripulações quanto as obras (casco) e cargas dos navios. Eles são percebidos

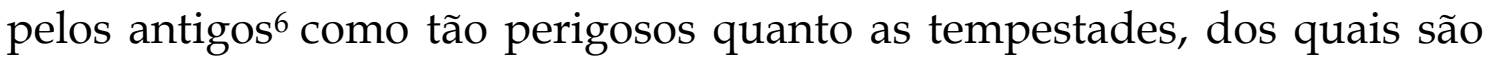
outra figura (Rougé, 1964; Rougé, 1968: 232).

Cada uma das principais bacias do Mediterrâneo possui características próprias, que variam na estação, e são sempre suscetíveis a aberrações, capazes de desafiar todas as probabilidades. Mas na maioria das vezes são bastante regulares, permitindo uma modelagem muito precisa das orientações e forças de ventos predominantes, para cada período do ano. Os Wind Charts do American Pilot permitem, hoje, ter para cada mês do ano e para todas as zonas de navegação uma ideia bastante clara das probabilidades do vento. As zonas e estações mais propícias à navegação em alto mar são aquelas em que os regimes são as mais regulares e as calmarias menos frequentes.

A figura 4, tirada das instruções náuticas alemãs (Mittelmeer-Handbuch do Deutsche Hydrographische Institut Hamburg), permite uma ideia dos principais regimes eólicos no mês de julho, no Mediterrâneo. Cada vento é simbolizado por uma linha correspondente à sua orientação, cujo comprimento corresponde a uma percentagem de dias durante os quais ele é estatisticamente constatado. No centro, figura a porcentagem de dias de calmaria. Ela ilustra bem a diferença entre a característica bem aleatória e pouco previsível dos regimes de vento no noroeste do Mediterrâneo, que associam muitos dias de calma e de orientações variáveis, e os encontrados no resto do Mediterrâneo, onde, pelo contrário, aparecem constantes muito

\footnotetext{
${ }^{6}$ Por exemplo, atos de verceli 5: "tenha o maior respeito por Pierre, graças a quem você e todos os outros reencontrarão a calmaria sem nenhum dano".
}

Heródoto, Unifesp, Guarulhos, v.4, n.1 - 2019.1. p. 327-394

DOI: 10.34024/herodoto.2019.v4.10124 
regulares, associando dominantes nítidas de orientações, próximas umas das outras, inscritas em um arco de $90^{\circ}$, e uma porcentagem muito baixa de calmaria. De um lado, um ambiente incerto, de outro, um espaço que deixa pouco espaço para surpresa. Estas condições, típicas do período de verão, e que tendem a se deteriorar à medida que nos aproximamos do fim da temporada de navegação, sem dúvida alguma, induziram práticas e tipos de rotas específicas. Para resumir, poderíamos dizer que uma travessia marítima ideal não excede a duração previsível de um vento de força e orientação compatíveis com sua prática.

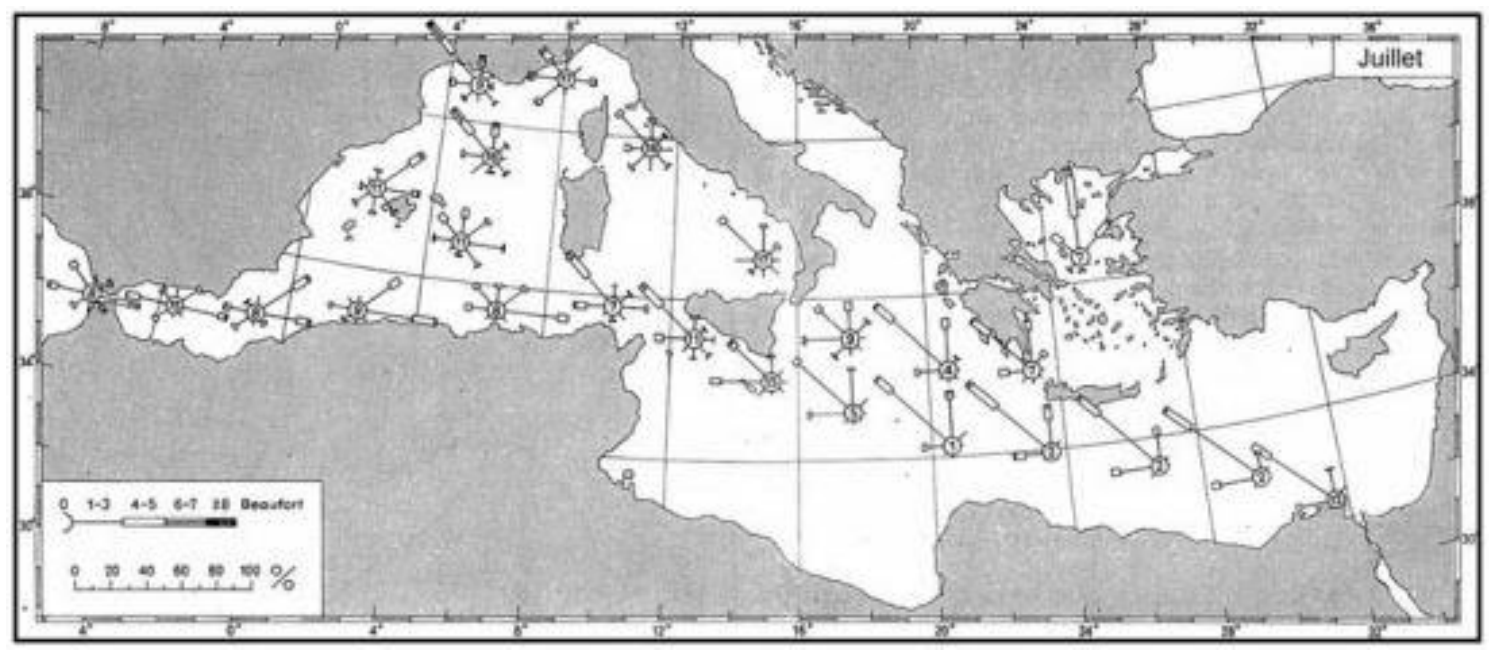

Fig. 4. Os regimes de vento durante o mês de julho no Mediterrâneo (MittelmeerHandbuch do Deutsche Hydrographische Institut Hamburg). Cada flecha indica a direção de um vento. Para cada uma delas, cada símbolo de traço indica uma força de vento, cuja largura indica a porcentagem para o mês. O número utilizado ao centro indica a porcentagem das calmarias. Notamos a extrema regularidade da bacia oriental do Mediterrâneo, assim como do sul de sua bacia ocidental, em relação à instabilidade dos setores Leão-Provença.

O texto de Estrabão insiste igualmente na ausência de excesso no regime eólico. Nunca será demais enfatizar quão pervertida é a nossa leitura da história da navegação comercial à vela, pelo imaginário moderno, que a marcou fortemente com o selo da aventura, ligada à história das grandes navegações. Das Grandes Descobertas ao Globo de Vendée (Vendée Globe), esse imaginário associa a navegação ao risco, à aventura, à performance e à ousadia. No entanto, nem o proprietário de um navio comercial, nem o fretador da carga, muito menos aquele que fez o adiantamento de um empréstimo para uma grande aventura, são naturalmente levados pela ousadia. Eles não visavam a velocidade ou o desempenho, mas sim a segurança dos negócios, e na maioria das vezes, devia ter o cuidado de não tentar a sorte, sem serem pegos pela surpresa ou por um imperativo maior.

Vemos logo que, em condições normais de manutenção e com uma tripulação experiente, os navios da antiguidade não eram menos

Heródoto, Unifesp, Guarulhos, v.4, n.1 - 2019.1. p. 327-394

DOI: $10.34024 /$ herodoto.2019.v4.10124 
marítimos do que os dos períodos que se seguiram, e que eles eram normalmente capazes de lidar com os caprichos de Éolo e Netuno. Por isso também, navegar na brisa não era, necessariamente, sua vocação primeira.

A força do vento exerce, de fato, uma influência em cascata sobre toda uma série de parâmetros de navegação. Antes de qualquer coisa, o poder do vento acrescenta dificuldade à manobra: a pressão exercida sobre as velas, e sobre as manobras. A vela deve ser reduzida gradualmente. Quanto mais a força do vento aumenta, mais o navio tem de abater, e quando o vento esfriava, a tendência geral parece ter sido a de escapar com vento traseiro, sob vela reduzida, quando não houvesse nenhuma terra na proximidade sob o vento. Em último caso, podíamos ser levados a abater o mastro, quando ele era suficiente por si só para impulsionar o navio, tal como fez a tripulação do navio de Paulo. Em qualquer outra mareação, as obras, vivas e mortas, bem como o aparelhamento, corrente e fixo, sofrem rapidamente, e o barco tende a fazer água, porque a tração dos ovéns disjunta as peças de afiada ao vento. Quando uma costa está sob o vento, o risco de deriva é alto, porque mesmo à lona seca [à sec de toile], tendo o navio suas formas próprias, ela participa, pela arqueação, à propulsão do navio, de uma maneira cujo efeito aumenta constantemente com a força do vento: o navio de Paulo é assim levado, à lona seca, de uma posição ao sul de Creta até a ilha de Malta, onde finalmente o vento arrebenta (Act Apost., 27; Pomey 1997). Mais uma vez, o conhecimento do meio presidiu a escolha de uma solução: devido à incapacidade de escapar, sob pena de ficar à deriva na Grande Sirte, e na impossibilidade de colocar-se ao través pela ausência de uma vela de estai, a solução da capa seca sobre âncora flutuante permitiu para dirigir o movimento do navio em uma direção grosseiramente perpendicular à do vento que normalmente ocasiona este tipo de capa, e, por vento norte, fazê-lo ir para o oeste, em direção ao mar aberto e não em direção a uma terra que se tornou ameaçadora. 


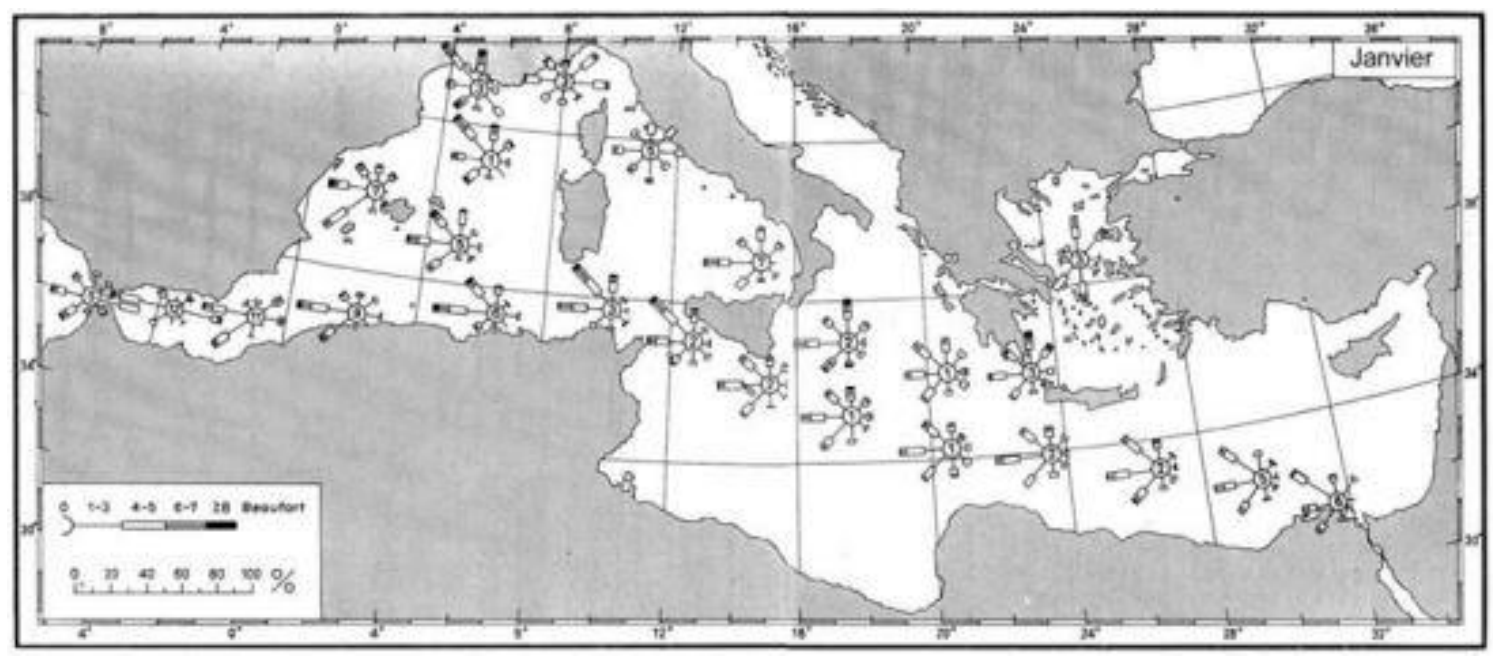

Fig. 5. Os regimes de vento no mês de janeiro no Mediterrâneo (Mittelmeer-Handbuch do Deutsche Hydrographische Institut Hamburg). Ressaltamos, em relação ao verão, a dupla tendência à instabilidade e às condições extremas (golpes de ventos, calmarias), ligada notadamente ao desaparecimento das brisas térmicas.

A força do vento determina também o estado do mar. A escala Beaufort foi precisamente elaborada a partir da referência ao estado do mar que gera um vento de uma determinada velocidade. As ondas do Mediterrâneo raramente atingem os valores do Atlântico, mas o seu comprimento mais curto e seu perfil torna-as muito quebrantes. Quanto mais o mar se forma, cava e tende a quebrar, mais ele influencia o progresso do navio e o conforto de seus ocupantes. Em popa rasada, o navio apanhado pela onda tende a surfar sobre seu cume e fugir do controle do piloto. De través [largo], o barco roda. Em bolina cerrada, ele balança, bate na onda projetando spray, e tende a embarcar água.

Valores que garantem o melhor compromisso entre conforto e velocidade são aqueles que se situam entre 3 e 4 Beaufort. A partir de 7 Beaufort, a situação rapidamente se torna crítica. Ventos frescos nunca foram populares junto aos marinheiros e comerciantes, e podemos facilmente compreendê-los, porque nunca se sabe quando um vento fresco deixará de esfriar, porque a partir de um certo limite, a segurança consiste em ceder ao vento, e porque nunca é bom para uma carga ser sacudida pela ondulação: ao risco de perda é adicionado o de uma ruptura na estiva e uma transferência repentina de carga sobre uma borda, levando inevitavelmente ao emborcamento do navio.

Para sermos completos, devemos finalmente evocar a maneira como o vento sopra e aquela como ele se levanta. À força igual, mesmo com fluxo de vento rápido, um navio é sempre mais fácil de manusear em um vento constante do que um vento tempestuoso. Algumas áreas do Mediterrâneo são também conhecidas pela imprevisibilidade de seus caprichos

Heródoto, Unifesp, Guarulhos, v.4, n.1 - 2019.1. p. 327-394

DOI: $10.34024 /$ herodoto.2019.v4.10124 
meteorológicos, e todos aqueles que o frequentam um pouco sabem que a brutal interrupção de um o vento pode dar lugar a uma reversão súbita e espetacular. Da mesma forma, alguns ventos, não o menor deles, podem se levantar e explodir violentamente sem sinais de alerta específicos.

As figuras 4 e 5 acima, também representam a proporção de forças do vento para cada orientação, para cada setor do Mediterrâneo, segundo um método mais diferenciado do que o "penon", dos Wind Charters, utilizado pela maioria das sínteses atuais: para o mês em questão, quatro estilos de linha definem quatro forças de vento, e o comprimento de linha define a norma estatística de presença de cada uma das forças para a orientação determinada pelo segmento. As forças superiores a 5 Beaufort definem condições difíceis para a navegação a extremos, em que era dificilmente possível navegar no mar, a não ser em popa rasada. Esse mapa nos mostra que em julho, os regimes mais extravagantes em termos de orientação também são os que tendem a exibir os valores mais elevados, definindo condições geralmente mais difíceis, em todos os pontos de vista. O vento modifica, enfim, as correntes de superfície, cuja incidência é raramente verificada com intensidade ao largo.

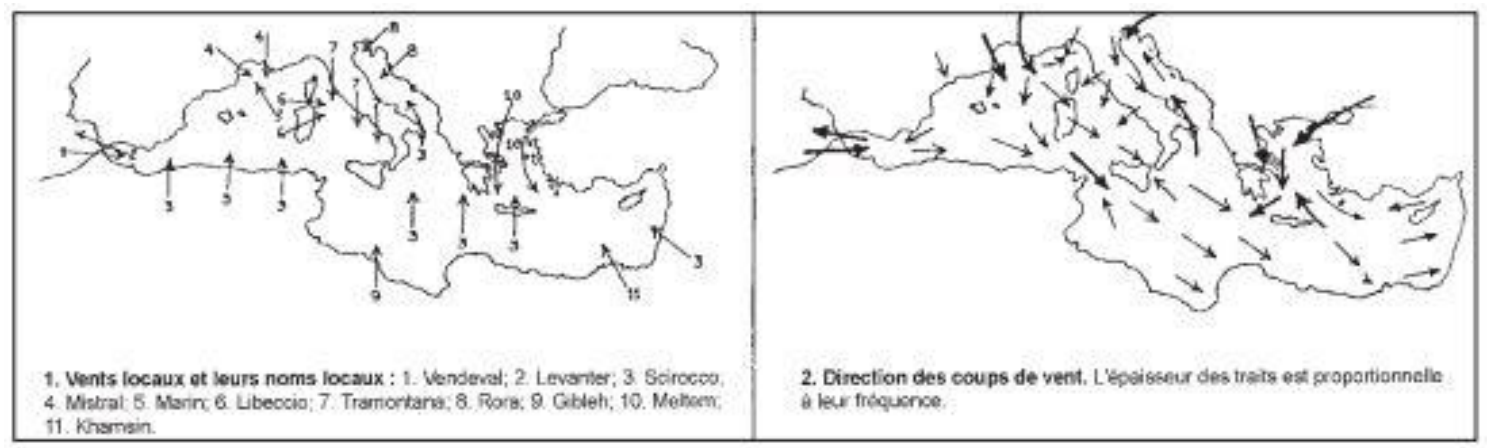

Fig. 6. Ventos dominantes (números) e correntes (setas) direção de tempestades de vento dominante no Mediterrâneo a partir de Trevor Hodge 1983. Estes mapas põem em evidência os ventos prejudiciais para navegação, que são aqueles geralmente apresentados nos mapas de ventos dominantes. Reparamos que estes golpes do vento são tanto mais raros e menos violentos à medida que as zonas são submetidas a regimes estivais estáveis. Eles destacam a frequência e a violência dos golpes de vento sobre o litoral do Languedoc e Provença, no Adriático e no mar Egeu, onde eles estão geralmente orientados para setor norte. Nas outras zonas, os golpes de mais frequentemente consistem em num simples reforço para além dos padrões do orientações dominantes.

O vento favorável é, em particular, tradicionalmente identificado com aquele que conduz na direção certa. A realidade é provavelmente mais complexa. Se o vento que garante uma "travessia feliz", de acordo com a expressão consagrada pelos antigos, é um vento de cauda forte o suficiente para assobiar o aparelhamento (Ael Arist., Orat., 36.111), desses ventos reputados a fazer o barco voar sobre as ondas, seria abusivo considerar como desfavorável, qualquer outro vento. Uma das mais importantes Heródoto, Unifesp, Guarulhos, v.4, n.1 - 2019.1. p. 327-394

DOI: 10.34024/herodoto.2019.v4.10124 
descobertas da humanidade foi, sem dúvidas, aquela que consistiu a conseguir fazer se movimentar um móvel em uma direção próxima daquela do vento que a impulsiona, em ocorrência, aquela que permite a um barco subir o vento, e portanto, mover-se em todas as direções.

A noção de vento contrário é, de fato, mais conveniente de manejar do que a de vento favorável, para nosso argumento. Vamos colocar nessa categoria, obviamente com graus variados, tudo o que não entra na primeira categoria. O vento contrário é o que confunde o navio e não permite que ele vá até onde quer. Todos os outros ventos tornam possível chegar onde se pretende, ao preço das condições de velocidade e conforto variáveis. A noção de vento contrário envolve, portanto, uma alquimia complexa que associa a força e direção do vento, por um lado, e as capacidades específicas de um casco, de um aparelhamento e de uma tripulação.

Portanto, exceto em casos extremos, é geralmente possível ir, ao preço de um certo número de inconveniências, contra a direção do vento, e não há oposição absoluta entre a afirmação de Estrabão, corroborado pela arqueologia - de um comércio particularmente ativo da Bética com a Itália e sua capital - e o de Posidônio, confirmado pela meteorologia - da existência nesta bacia, de regimes de leste dominante, teoricamente contrários a essa relação, mas intransponíveis apenas em condições particulares.

O regime de ventos dominantes determina, portanto, soluções confortáveis e outras menos, impõe rotas mais ou menos diretas e tempos de espera mais longos ou mais curtos, mas nunca apresenta, em condições normais, absoluta impossibilidade de navegação. Então nós não podemos em nenhum caso considerar que as condições naturais impunham necessariamente passar por um ponto e não outro, de maneira invariavelmente e perene. No entanto, a estrutura é clara o suficiente para sugerir as que poderiam, e que geralmente continuaram a ser, as soluções racionais ou não. Vamos dar um exemplo concreto: a travessia da embocadura de Bonifácio. O estreito curto que separa a Córsega da Sardenha é marcado por ventos e correntes dominantes do Oeste, que geralmente sopram com bons valores de brisa. Certamente, não é absolutamente impossível atravessá-la de leste a oeste: é suficiente para tal, esperar por uma reversão de leste, o que no verão pode levar mais tempo do que o contorno da ilha, ou tentar um bordejo perigoso em um espaço estreito e cheio de ilhas e baixios, com o risco de ser levado para a costa na primeira viragem errada. É muito duvidoso, nestas condições, que a travessia de leste para oeste fosse uma prática normal, ou, em todo caso, simples e natural, durante os meses de verão (Arnaud, 2005). Não é de se Heródoto, Unifesp, Guarulhos, v.4, n.1 - 2019.1. p. 327-394

DOI: 10.34024/herodoto.2019.v4.10124 
excluir, no entanto, seja em outras estações, seja ao preço das limitações que acabamos de mencionar.

Parece-nos essencial admitir que, para os antigos, o vento desfavorável não era necessariamente um vento mal direcionado, mas um vento soprando com uma força tal que sua direção não permitia mais chegar a um determinado destino. Esta ideia parece-nos confirmada por uma passagem muito famosa, onde Luciano de Samósata (Nav., 7), contemporâneo de Marco Aurélio, descreve a difícil navegação de um navio de grande porte, de Alexandria, desviado pelo mau tempo à Atenas, onde a chegada deste gigante dos mares fizera sensação. Por conta do vento fraco [petit temps], o piloto tinha optado em Faros por uma travessia direta que o levou ao Cabo Acamas (Arnauti) do Chipre. Dadas as condições que normalmente governam esta bacia, e a ausência normal de ventos bem orientados, podemos supor que ele navegou por fluxo de oeste para noroeste e por uma mareação próxima ao vento de través. Quando Luciano aponta que, em vista do Cabo Acamas, a oeste do Chipre, um fluxo de Ponante os pegou de través e os levou a Sídon, a observação do mapa nos mostra que o piloto escolheu uma mareação de fuga em popa rasada correspondente a um fluxo noroeste. Neste caso, o que transformou o vento favorável em um vento desfavorável fora menos uma mudança de orientação do que uma mudança de força, o que explica, sem dúvidas, as particularidades do aparelho desses navios desprovidos de velas de estai. 


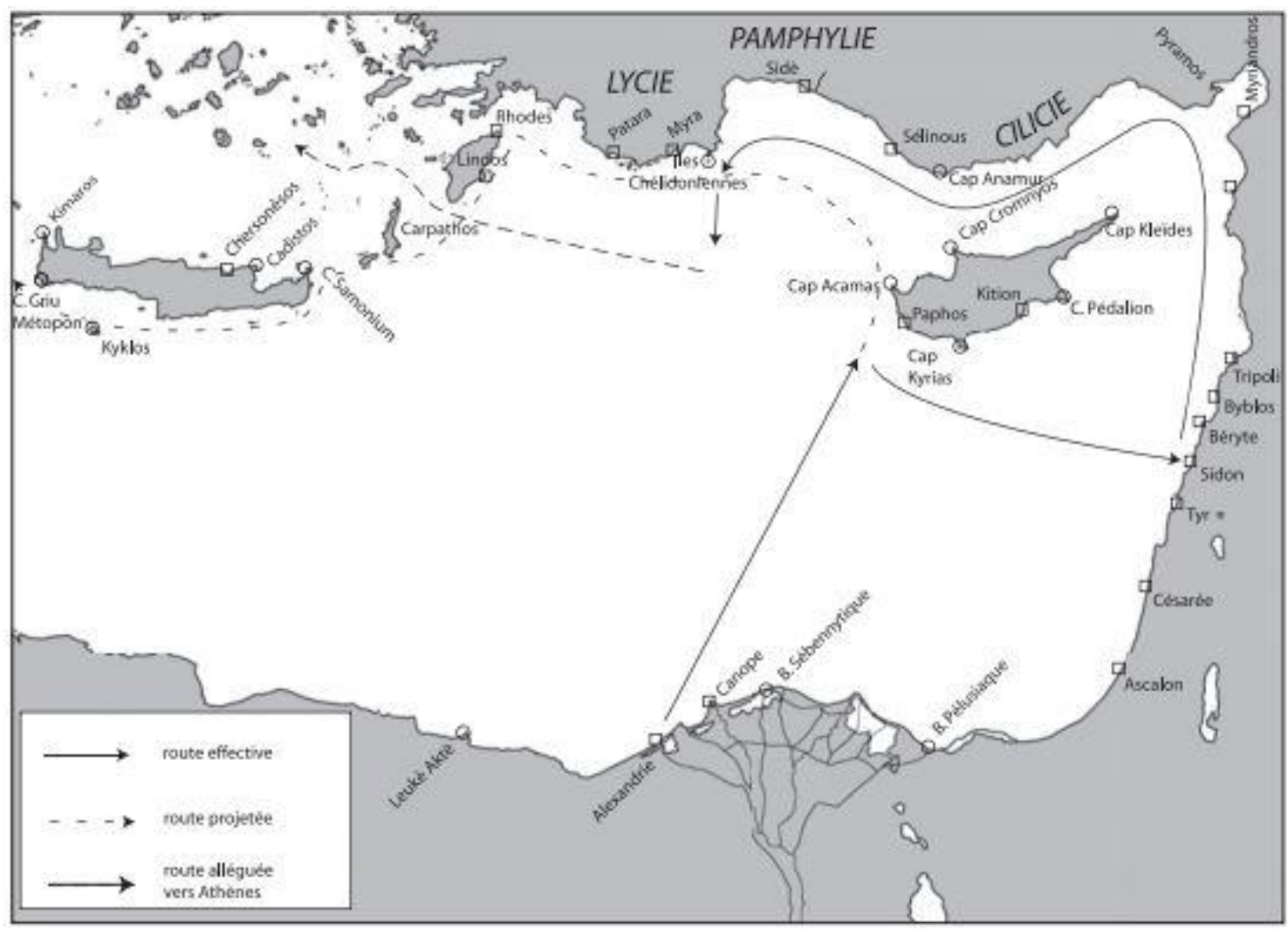

Fig. 7. A navegação do Isis, a partir do relato de Luciano (P.A.). Esse itinerário é uma ficção, cuja característica verossímil é geralmente aceita até no que diz respeito à passagem pelas ilhas Caledonianas - ou "ilhas das Andorinhas" -, a sequência da viagem sendo geralmente considerada como mais suspeita e não tendo outra finalidade que a de conduzir o navio ao Pireu.

Em uma palavra, portanto, existia para os antigos ventos reputados a impedir a navegação em uma direção determinada, ao ponto de gerar cláusulas especiais nos tratados ou práticas que regiam o comércio marítimo (Heródoto: 2. 179); o vento favorável é, por excelência, o vento de popa, que carrega com vigor sem excesso na direção desejada, isto é, uma brisa de popa. Mas esse tipo de vento é, sem dúvida a exceção, aquela que testemunha o favor dos deuses. Ambos os textos que acabamos de analisar mostram que é impossível separar condições naturais dos parâmetros técnicos, e que na definição de vento favorável, a força é o critério primordial, e orientação um critério secundário. Um vento é considerado praticável em pequenos ares até o máximo das capacidades teóricas de subida do navio. Na brisa, ele é normalmente apenas às mareações de popa (vento traseiro, largo). 


\section{Brisas térmicas}

Esse fenômeno é uma das características maiores do regime de ventos do Mediterrâneo. Resulta de uma diferença de temperatura de pelo menos $3^{\circ}$ $C$ entre a terra e o mar e é condicionada pela presença de um céu claro que facilita a radiação. A brisa sopra da terra durante a noite e do mar durante o dia. Elas são separadas por dois períodos de calmaria de duração variável, mas podem, em alguns casos, atingir um total de 7 ou até 8 horas: uma precede a volta [renverse], ao anoitecer, a outra entre o nascer do sol e cerca de uma hora antes do zênite. Dependendo do caso, ou elas desaparecem em face dos ventos estabelecidos, ou combinam-se com eles para modificar temporariamente a potência ou mudar a orientação.

Este fenômeno é, de fato, estritamente limitado à zona litoral, e contribui para criar dois conjuntos meteorológicos distintos, se não opostos: as costas e o largo. Concorda-se que o limite absoluto do efeito da brisa está situado a uma distância de aproximadamente 20 milhas da costa. Este é o máximo em casos de brisas costeiras sustentadas. A experiência prática mostra que, por via de regra, diminuem regularmente até tornarem-se insignificantes a partir de 10 milhas. Elas são praticamente reservadas para a cabotagem e não pouco contribuíram para popularizar a opinião errônea de que a navegação antiga se reduzia inteiramente a essa prática. Entender-se-á que este regime não permite a navegação ao largo. Além do efeito da brisa costeira, apenas os ventos estabelecidos podem mover a embarcação. Por outro lado, quando as relações de longo alcance seguiam um trecho de costa, o fluxo de calor poderia fornecer um propulsor inestimável na ausência de um vento estabelecido. No entanto, a morfologia do Mediterrâneo deixa pouco espaço para rotas inteiramente marítimas, exceto no caso de relações relativamente curtas, e deve-se certamente imaginar que a maioria das relações de longa distância envolvia uma combinação de diferentes tipos de ambiente, impondo tempos e práticas de navegação variadas.

O princípio da brisa terrestre e da brisa do mar não deve fazer imaginar um sopro sempre perpendicular à terra e simplesmente invertido. Quando este é o caso, ele realmente permite uma navegação cruzada [de través]. Mas muitas vezes, a morfologia do litoral induz brisas mais ou menos paralelas à linha da costa, impondo lançamentos regulares durante a duração do sopro contrário e a escolha de uma navegação diurna ou noturna.

É também um fenômeno muito desigual em potência e em regularidade, de um setor para outro. Como todos os ventos, elas aceleram à passagem de ilhas e cabos e, por vezes, seu sentido é invertido. Se elas podem atingir

Heródoto, Unifesp, Guarulhos, v.4, n.1 - 2019.1. p. 327-394

DOI: 10.34024/herodoto.2019.v4.10124 
até 20 nós, as estatísticas mostram que os ventos muito fracos e as calmarias podem ser insistentes em algumas áreas. De junho a setembro, os ventos fracos atingem, por exemplo, frequências recordes no Golfo de Gênova, onde eles representam mais de $70 \%$ do período. Eles ainda são mais de $50 \%$ sobre Elba /Leste da Córsega, mas são apenas cerca de 45\% na Córsega Ocidental e entre 30 e 35\% em Leão e na Provença.

\section{As correntes}

Se as correntes do Mediterrâneo só excepcionalmente alcançam valores comparáveis aos gerados no Atlântico pelas marés, estão longe de serem insignificantes e, a defeito de não afetarem seriamente o curso, podem exercer uma influência muito sensível na velocidade dos navios. Pelo efeito da rotação da Terra, um fluxo permanente flui ao longo das costas na direção oposta das agulhas de um relógio. Esse fenômeno, que se desvanece à medida que nos afastamos da costa, é caracterizado por uma velocidade média de fluxo de 0,5 nós, o que é bastante importante para navios pouco rápidos. Dois navios operando na mesma velocidade de superficie de 4 nós, mas na direção oposta, exibiriam em velocidade real (ou velocidade de fundo) um desvio de 1 nó equivalente a $1 / 4$ da sua

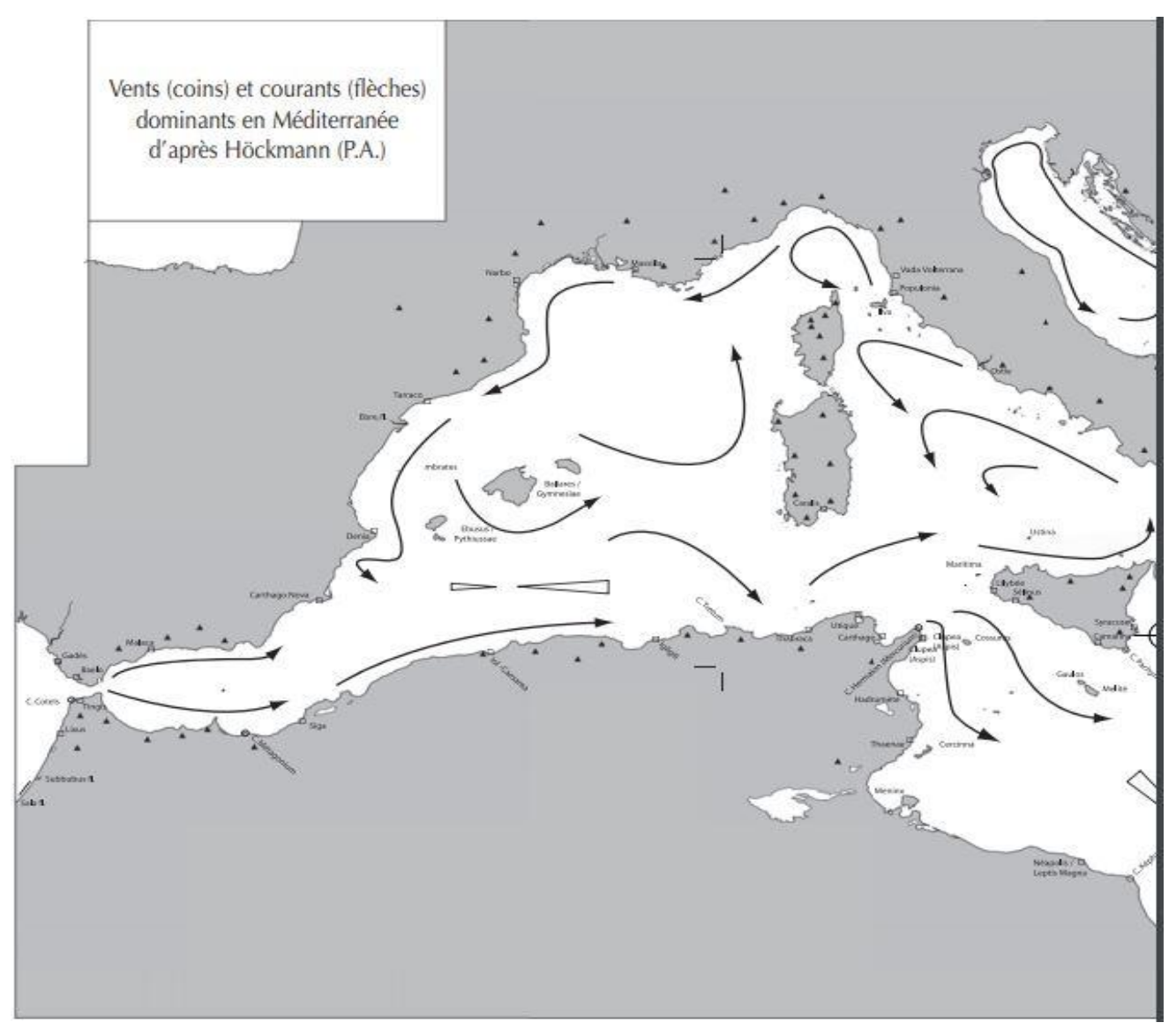

Heródoto, Unifesp, Guarulhos, v.4, n.1 - 2019.1. p. 327-394

DOI: 10.34024/herodoto.2019.v4.10124 
velocidade nominal teórica, dependendo de estarem navegando a favor ou contra a corrente.

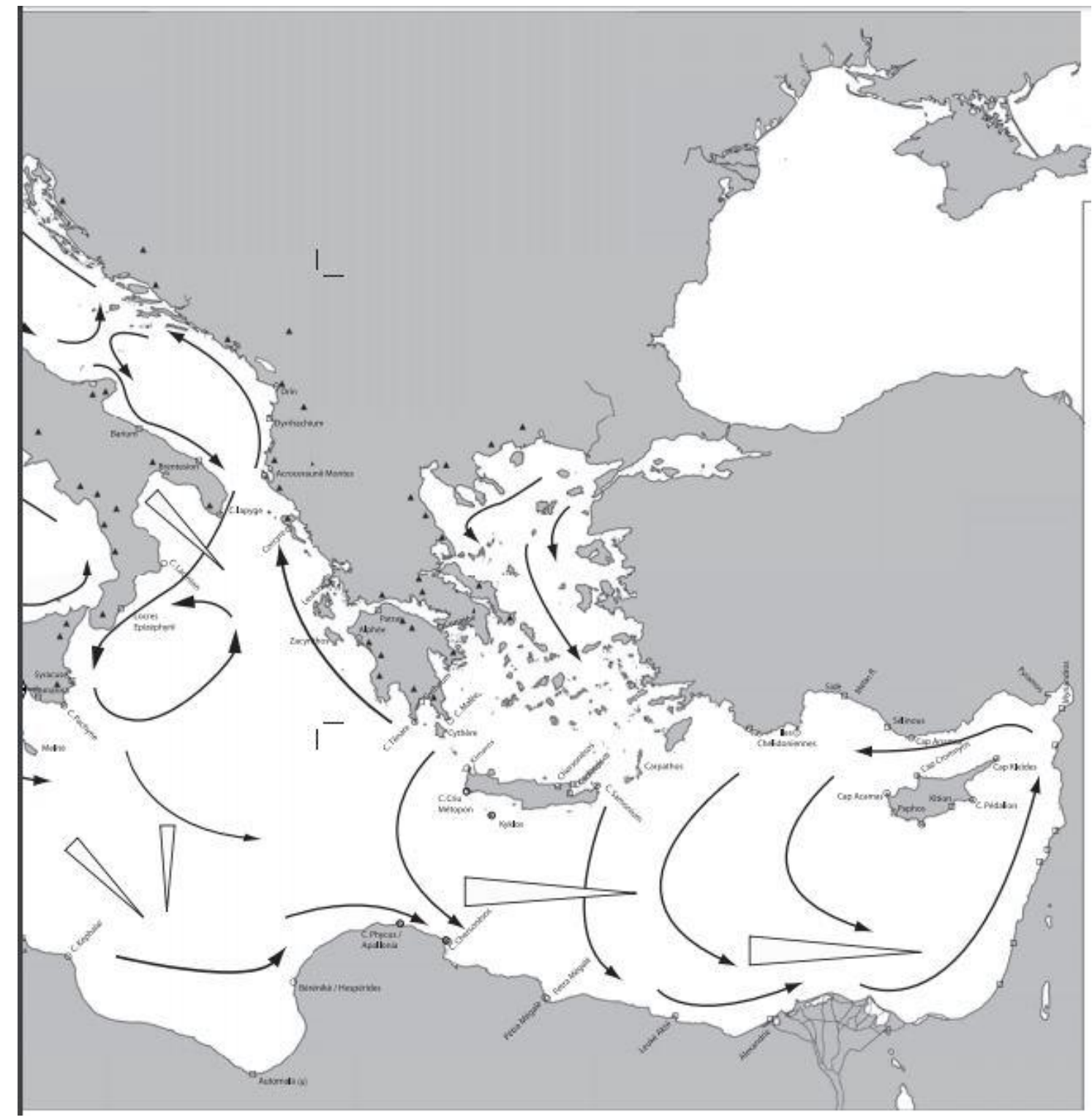

Fig. 8. São ilustrados aqui ventos estabelecidos suscetíveis de serem utilizados pela navegação, e não os acidentes do tipo de rajadas de vento.

Toda uma série de causas pode levar à aceleração desses fluxos e contribuir para transformá-los em auxílios à navegação ou em problemas sérios. Fenômenos de maré são um dos mais espetaculares. Eles são encontrados no Atlântico, é claro, especialmente nos estuários e nas proximidades de Gibraltar, mas eles também são encontrados em todos os principais estreitos do Mediterrâneo (embocadura de Bonifácio, Estreito de Messina, Canal da Sicília, Canal do Chipre, Canal de Creta, Canal de Cerigo, Dardanelos, Bósforo) ou ainda no Grande Sirte. Além desses casos particulares, e, portanto, limitados e bem conhecidos dos marinheiros, Heródoto, Unifesp, Guarulhos, v.4, n.1 - 2019.1. p. 327-394 
apenas condições especiais podem tornar as correntes em problemas reais, especialmente quando são aceleradas por um vento do qual compartilham a direção oposta. Mas neste caso, o vento é geralmente o principal problema.

Que as correntes possam acelerar ou retardar a navegação costeira é um fato inegável, mas é preciso guardar cautela antes de conferir uma importância excessiva ou inferir que eles poderiam impossibilitar a navegação em um sentido determinado. O caso dos Dardanelos é, sem dúvida, o mais impressionante, porque se relaciona com o espaço mais largo ( 25 milhas), onde são sentidas correntes de grande potência (até 3 nós no lado asiático do rio, na entrada do estreito, em média, cerca de 2 nós além, mas até 5 nós em um vento norte estabelecido). No entanto, estas condições eminentemente desfavoráveis nunca proibiram subir os Dardanelos, nem na Antiguidade nem nos tempos modernos. Aprendemos a descobrir as fraquezas da corrente seguindo sua costa europeia e a realizá-la apenas com um vento favorável de um mínimo de potência (Denham, 1970: 86). O preço a pagar era o de esperar em algum ancoradouro seguro pela chegada de tais condições. É notável que, além do caso dos Dardanelos, para os quais nos descreveram precisamente os arranjos humanos que permitiram administrar essas correntes (Strabon: 13.1.22), as fontes antigas são geralmente silenciosas sobre as correntes. $\mathrm{Na}$ maioria das vezes, elas não descrevem uma corrente, estritamente falando, mas o fluxo exitoso do navio.

\section{Sazonalidade, limite e sorte da navegação}

A maioria dos trabalhos recentes (Morton, 2001; Mc Cormick, 2002: 98, 255268) enfatizam corretamente a "sazonalidade" na prática da navegação. Não acreditemos que estações inteiras resultariam em uma desertificação da superfície do mar, como às vezes imaginamos, com base em um equívoco do conceito de "mar fechado". No entanto, é inegável que a temporada de inverno se traduz não só pela instabilidade do regime climático, mas por uma tendência generalizada para a exacerbação de fenômenos meteorológicos, caracterizada tanto pela rarefação de brisas térmicas e pelo aumento proporcional de ventos frescos a violentos, por um lado, calmaria do outro.

Mas as maiores variações nos padrões de vento de uma estação para outra, na maioria das bacias, não limitaram seus efeitos à frequentação do mar, e não foram reduzidas a uma oposição binária entre uma estação boa e uma ruim. Durante o período amplo do "mar aberto", elas oferecem condições 
altamente variáveis, que certamente definiram diferentes rotas de acordo com as estações do ano. Os dois meses de verão, durante os quais os regimes de vento são muito mais estáveis do que os conhecidos em qualquer outra época do ano, não devem nos fazer esquecer que a primavera e os meses de setembro a outubro ofereciam também vastas possibilidades de navegação, muitas vezes irredutíveis aos regimes etesianos, que a erudição tende a tomar como referência exclusiva.

Onde quer que existam regimes etesianos, eles desempenharam, sem dúvida, um papel considerável, tanto positivo como negativo, na prática da navegação. Eles são temidos em uma direção de navegação e explorados na outra. Se, durante a duração de sua manifestação, eles excluem a prática de navegação em uma determinada direção, a partir de um certo número de portos, esta situação não é absolutamente permanente, o que pode determinar tanto calendários de rotações quanto itinerários que variam de acordo com as estações do ano. Então que Agripa II estivesse prestes para embarcar em Brundísio para retornar à Judéia, por exemplo, Calígula teria lhe aconselhado, de acordo com Philo de Alexandria (in FLACC. 26), "a desistir da navegação de Brundísio na Síria, muito longa e fatigante, e esperar pelos ventos etésios, pegar o atalho de Alexandria; porque o transporte de lá vai rápido e seus pilotos têm uma grande experiência: como os cocheiros dirigindo os cavalos de corrida, eles garantem a rota direta, sem se desviar ". Esse texto destaca pelo menos três fatos essenciais:

- Que as rotas são, ao menos para certos setores do Mediterrâneo, fortemente especializadas, e que existe para cada frota itinerários recorrentes, sem dúvidas relacionados tanto ao peso das tradições quanto a uma exploração realista do meio, garantido por gerações de experiência;

- Que certas rotas, como as rotas normais entre o Canal Otranto e o Levante, por não desfrutarem de regimes particularmente favoráveis, deviam recorrer a longos e tediosos itinerários de cabotagem, que mantinham uma conexão entre o sudeste e noroeste do Mediterrâneo centro-oriental, em todas as estações;

- Que existiam rotas mais diretas, como a do Egito, que explorava, de Roma a Alexandria, os ventos dos etesianos, graças aos quais se podia alcançar tempos recordes de percurso (Pline, $H N, 19,3$ ): 5 a 6 dias desde o estreito da Sicília, até 8 dias a partir de Pozzuoli. Era necessário somente esperar, para usar o período favorável.

As rotações dos navios entre o Egito e a Itália ilustram essa sazonalidade, que impõe itinerários e calendários de navegação precisos (Rougé, 1966: 87), e aos quais R. Duncan Jones foi sensível, quando enfatizou a existência 
de temporadas rápidas e temporadas lentas nas relações entre Roma e Egito (1990: 27). A documentação papirológica ${ }^{7}$ sugere que a tendência era para uma chegada antecipada na Itália, entre maio e junho, mas às vezes mais cedo, antes dos etésios, que normalmente se estabelecem no início de julho, para que retornassem aproveitando-se desses ventos. Na ida, a rota de Cirene, em maio-junho, era sem dúvida preferida ${ }^{8}$, pois tirava proveito do Gibleh [Sirocco], um vento meridional estabelecido por pelo menos três dias; no final da temporada ou durante os etésios, a rota pelo Chipre era provavelmente preferível. Um desses papiros nos mostra que, nos primeiros dias de agosto, a frota não teria permissão para sair de Portus ainda, e um certo nervosismo fica evidente na carta, porque, nessa data avançada, o final da temporada de ventos etésios se aproximava. Mas é a condição de um retorno rápido. Para os navios que retornavam a Alexandria em julho-agosto, uma meia rotação adicional desde Alexandria, bem atestada nos Atos dos Apóstolos, era possível no final do verão e início do outono. Ela tomava então a rota oriental por Chipre e Rodes, possibilitada pelo fim dos ventos dos etésios.

A natureza muito limitada da documentação não permite se basear mais do que numa impressão do ritmo sazonal das rotas. No entanto, ela é bastante consonante com os dados dos arquivos Genizah, que nos mostram que no século XI-XII, o porto de Alexandria experimentava uma grande agitação, durante a segunda quinzena de abril e em maio, seguida por uma rápida desaceleração, até meados de agosto e setembro, quando há uma segunda onda maciça de partidas (Udovitch, 1978: 531). De fato, as partidas enquadram simplesmente o período dos ventos dos etesianos, que são, para um grande número de navios desejosos de deixar o Egito, ventos contrários.

Estas variações sazonais certamente mudaram a distribuição estatística dos barcos usados durante cada estação. Algumas embarcações invernavam, sobretudo os grandes transportadores; outras não. Sabe-se que a propulsão mista permitia, dentro de certos limites, de se livrar de situações que, sem dúvida, teriam sido impossíveis com propulsão somente à vela, e pode-se supor que as embarcações mistas eram estatisticamente melhor

\footnotetext{
7 Sel. Pap. 111 (século II) = P. Mich. 491, cf. P. Mich. 490: chegada em 20 de maio; Sel Pap. 112 (século II-III) : chegada a Portus, em 30 de junho. ; descarregamento em 12 de julho; com o resto da frota, o navio é ainda em espera da dimissoria em 2 de agosto. Em contrapartida, contra a opinião de Rougé $(1966,87)$, não parece possível de deduzir desse texto que os navios chegaram em comboio. O navio sobre o qual Paulo embarca de Malta chega bem mais cedo, sem dúvida, em fins de fevereiro.

8 Apolinário, o recruta da frota de Misene, a quem devemos o P. Mich. 490, menciona, na carta que ele envia à sua mãe quando chega na Itália, uma carta precedente, confiada, em rota, à Cirene, a um terceiro que se dirigia ao Egito.
}

Heródoto, Unifesp, Guarulhos, v.4, n.1 - 2019.1. p. 327-394

DOI: 10.34024/herodoto.2019.v4.10124 
representadas na estação invernal, com destaque às unidades de baixa tonelagem, que reduziam o risco comercial, por causa de seus baixos volumes, por serem mais manobráveis e por poderem encontrar um maior número de abrigos. Mac Cormick (2001: 463) definiu razoavelmente bem os quadros dessa navegação costeira de inverno, que consistia em esperar em um abrigo por uma janela meteorológica favorável que fosse explorada o máximo possível, antes de se por em segurança em outro ancoradouro abrigado, aguardando o retorno de condições favoráveis para a continuação da viagem.

A sazonalidade é asseguradamente, para certos lugares, um dos limites da navegação antiga, na medida em que os itinerários não são praticáveis em qualquer estação, mas é também o que permitiu às frotas antigas se livrarem do diktat das condições estivais. Parece essencial, a este respeito, reagir contra uma forma de neo-determinismo muito na moda recentemente, em alguns autores anglo-saxões (Pryor, 1988: 7-24, HordenPurcell, 2000: 137-143) - que tende a se concentrar nos únicos ventos dominantes definidos pelos regimes dos meses de verão, para enfatizar as restrições e os sistemas de exclusão que de fato limitavam o padrão de navegação no Mediterrâneo a duas rotas costeiras, uma meridional, outra setentrional, excluindo qualquer outra solução. As outras soluções existiam, à condição de espera e ajuste do calendário comercial aos potenciais conjugados das inter-estações e dos dois meses de verão. O mar não é um espaço simples atravessado por rotas reversíveis. Não é nem um liame, nem um separador. Ele é por vezes tanto um, quanto o outro. De uma estação a outra, ele aproxima, distancia ou separa os lugares entre os quais ele se interpõe.

Em resumo, deve-se notar que a prática de navegação marítima é inseparável da existência de ventos predominantes de força e orientação compatíveis com a direção desejada, e suficientemente estabelecidos para indicar a probabilidade de sua manutenção por um período pelo menos igual àquela normalmente esperada para a travessia. Em todos os casos de períodos ou zonas caracterizados por instabilidade e tendência extrema de ventos estabelecidos, ou pelos regimes de brisas térmicas dominantes, a cabotagem, por outro lado, deve aparecer como a única solução aceitável, ou pelo menos, como o mais razoável.

As rotas, portanto, não são uma realidade abstrata ou intangível. Resultando de intenções comerciais, elas são um compromisso permanente entre o homem e o ambiente no qual ele evolui, e elas variam com o sentido do curso, mas também com as estações, entendidas aqui em um sentido amplo, como o conjunto de variações periódicas, sensíveis e regulares, de 
regimes meteorológicos suscetíveis de serem apreendidos pela experiência dos homens do mar.

À esta altura da apresentação, é necessário introduzir dois outros parâmetros naturais não relacionados com a propulsão do navio, que exercem, no entanto, grande influência na prática da navegação. Estas são a natureza da costa e a visibilidade.

\section{A natureza da costa: armadilhas e abrigos costeiros}

Nunca se pode repetir o suficiente que, para o marinheiro, o perigo é sempre a terra, mais do que o mar. Qualquer costa sob um vento dominante violento se torna uma armadilha onde a onda cava e quebra, onde os ventos aceleram e se reorientam de acordo com os relevos costeiros, cabos e ilhas, e em que a atitude normal do marinheiro é, na presença de perigo, buscar a segurança do alto mar, como o piloto do Ísis que, diz Luciano, reconhece a proximidade das Rochas Caledônias e da costa Lícia graças a um fogo providencial - sem dúvidas um farol - vira imediatamente de bordo em busca da segurança do alto mar. De fato, os cemitérios de navios se encontram mais ao longo das costas que em alto mar.

As costas desempenham, portanto, um papel determinante para a segurança da navegação costeira, e sua natureza, definida pelos fundos, endentações e relevos da costa, torna-as, a este respeito, muito diferentes. As linhas costeiras arenosas, geralmente baixas e não muito visíveis, e por isso perigosas, também são caracterizadas mais frequentemente por pequenos fundos, dobrados de bancos de areia móveis em áreas estuarinas. Elas geralmente não são muito apreciadas pelos marinheiros. Embora as costas rochosas ofereçam frequentemente um aspecto repulsivo, elas são geralmente preferidas pelos marinheiros, e são as únicas que um autor grego pode descrever como de eulimènaï "felizmente dotadas de portos por natureza", desde que, no entanto, possuam ancoradouros suficientes, sem qualquer dificuldade particular de acesso. Quando não estão localizados em uma costa de barlavento, os cabos costumam oferecer muito bons abrigos. Trechos inteiros de costas rochosas só são impróprios à ancoragem, ou porque são mal expostos, em uma costa de barlavento, ou por causa de baixios que impossibilitam o acesso. Além de casos raros de recifes submersos longe o suficiente no mar, e salvo a passagem no raso da costa, o perigo de armadilhas se apresentavam somente na fase de aterragem, e com um bom conhecimento dos lugares, os alinhamentos de 
conhecenças certamente permitiam que os pilotos fizessem o caminho mais seguro do que por sonda.

Estrabão (4.6.2) nos dá um bom exemplo do que, a seus olhos era uma costa inóspita, "todo o litoral desde do porto de Monoikos (Mônaco) até o Tirreno é, ele nos diz, exposto aos ventos (proséchès) e privados de abrigos portuários (aliménos), com a exceção de ancoradouros estreitos (Brachéïs Hormoi) e ancoragens pouco profundas (angkyrobôlai)". Mas antes mesmo de oferecer um abrigo ou representar uma ameaça, a costa é o ponto de referência mais preciso do qual dispõe o marinheiro, e a altura de uma costa determina uma diferença radical e essencial à prática da navegação, entre as costas baixas e as costas elevadas. Ela coloca todo o problema da visibilidade e da navegação visual.

\section{Visibilidade e orientação}

Se a paisagem no alto mar é geralmente pouco variada e tende a ser limitada a um horizonte mais ou menos claro, dois parâmetros regem seu aspecto: a transparência do ar e a curvatura da terra ${ }^{9}$, que define a distância a que um objeto é teoricamente visível de acordo com a sua altitude. Nos meses de verão, a transparência do ar geralmente garante uma visibilidade no Mediterrâneo superior a 10 milhas náuticas, exceto sob tempestades, ou no caso de bancos de neblina de radiação, que às vezes se formam durante a noite ao longo da costa, e que as brisas empurram em direção ao largo, paralelamente às costas, especialmente em agosto, e que o sol nem sempre é suficiente para dissipar.

Em uma atmosfera límpida, a distância em que um objeto é teoricamente visível é definida por sua altitude: um litoral de $2 \mathrm{~m}$ de altura é visível, a partir do convés de um barco, somente a 2,9 milhas. Um ponto localizado a uma altitude de $500 \mathrm{~m}$ é visível a uma distância de 46,9 milhas, correspondendo para uma embarcação viajando a 3 nós, a um trajeto de mais de quinze horas. Um pico de $1000 \mathrm{~m}$ é teoricamente visível a uma distância de 66,4 milhas. Com tempo limpo, a Córsega, distante 120 milhas, é perfeitamente visível das alturas de Nice. Subir no mastro permite que o vigia aumente o alcance de sua visão. Várias representações da Antiguidade nos mostram gáveas ocupadas por vigias, na ponta do

\footnotetext{
9 A fórmula da distância (D) de visibilidade ótica máxima teórica imposta pela curvatura de a terra é: $D=2,2(\sqrt{h}+\sqrt{ } H)$ onde $h$ e $H$ são as respectivas altitudes do ponto de observação e do ponto observado.
}

Heródoto, Unifesp, Guarulhos, v.4, n.1 - 2019.1. p. 327-394

DOI: 10.34024/herodoto.2019.v4.10124 
mastro, e podemos assim concluir que um grande toneleiro, assumindo mastros mais altos, também aumenta a distância teórica de visibilidade.

No entanto, é importante permanecer extremamente cauteloso em relação aos mapas de visibilidade elaborados para o Mediterrâneo, como o de Schüle (1968, fig. 1) reproduzido por Horden e Purcell (2002, 127). Eles tendem a banalizar a imagem de um Mediterrâneo amplamente aberto a uma navegação visual, mesmo a grande distância das costas, ao passo que eles definem apenas uma possibilidade puramente teórica, definida pela geometria dos corpos esféricos, e que ignora fatores acidentais da visibilidade, como a meteorologia. Na realidade, a Córsega, reputada visível do leste da Provença, raramente o é, geralmente no inverno, nos dias em que o Mistral cria um ar particularmente limpo, e para um observador colocado a uma altitude de pelo menos de cem metros. Por outro lado, ela é visível apenas excepcionalmente a partir do nível do mar. $\mathrm{Na}$ época de mar aberto, a neblina devida à evaporação e o spray são suficientes para obscurecer significativamente a visibilidade e reduzi-la, à cerca de vinte milhas em ótimas condições.

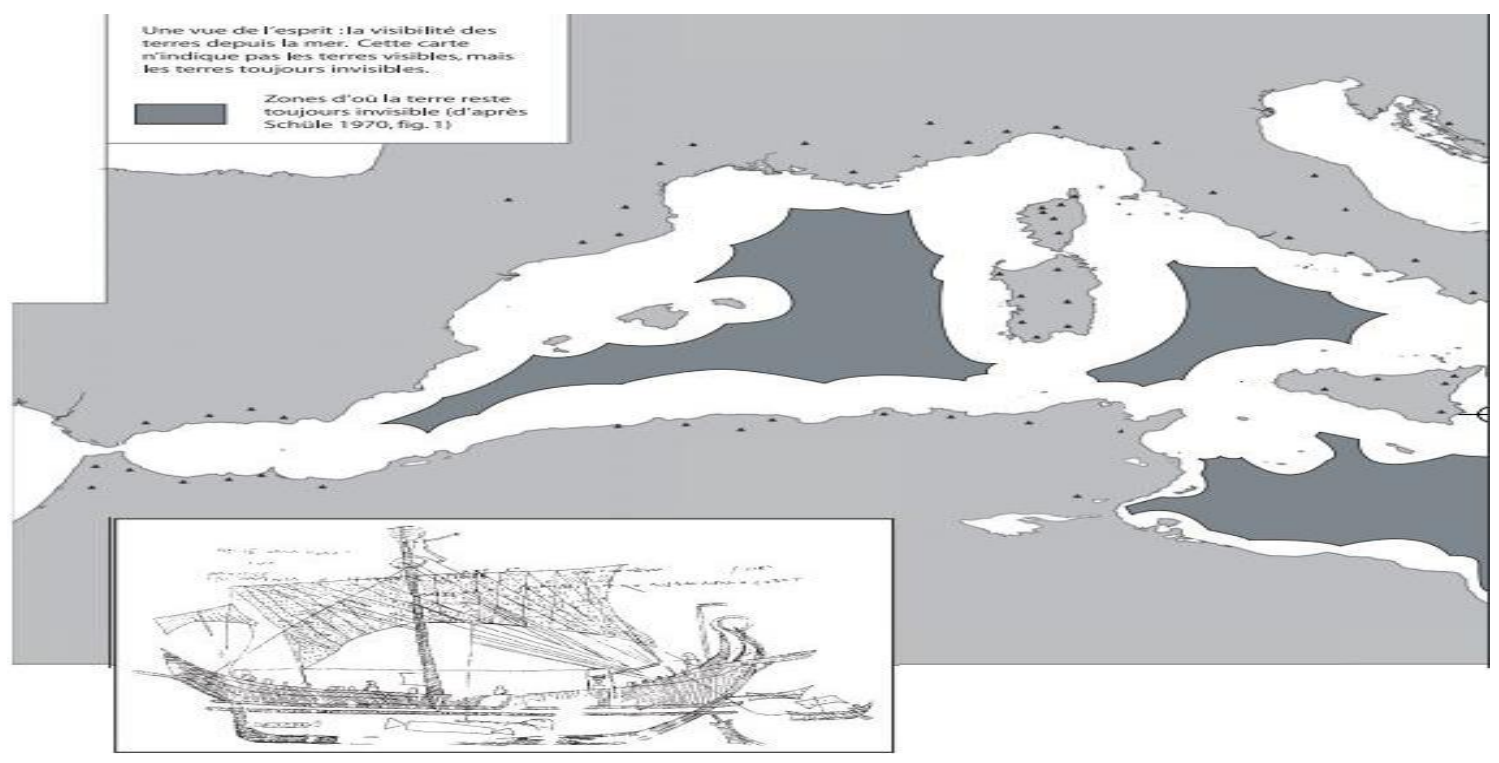

Fig. 9. O Navio Europa, a partir de um grafitti de Pompéia. Como a maioria dos grafittis realizados por marinheiros, esses colocam em evidência detalhes que chamam pouco a atenção de terrestres: a forma imersa da carena - o que supõe que os autores eram familiarizados com formas vistas de carenagem -, contra a verossimilhança geral de desenhos que representam o navio no mar, e o aparelho corrente. Remarcamos na representação, rara, um vigia na gávea, na ponta do mastro. 


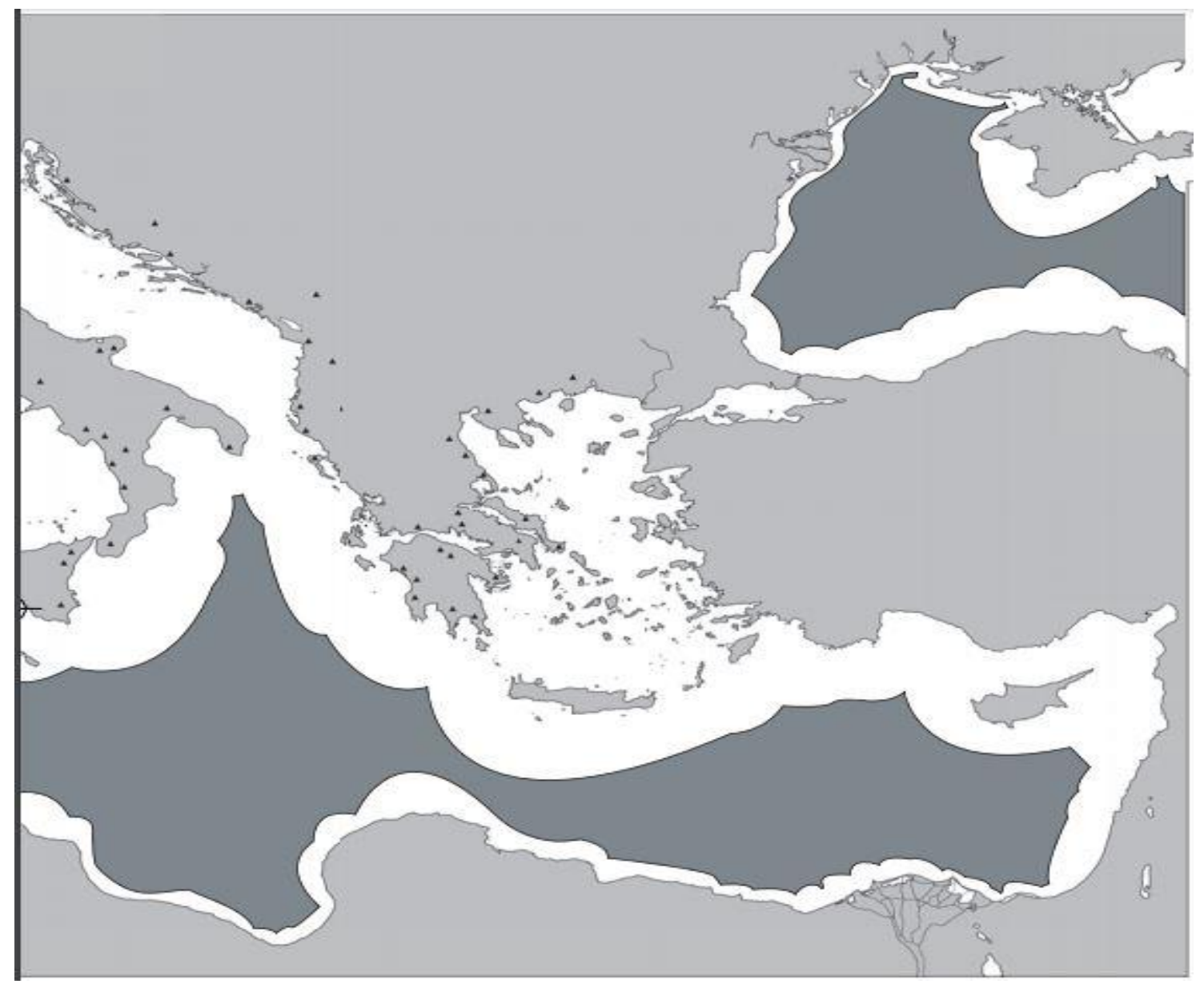

Fig. 10. A visibilidade das costas, desde o largo, a partir de Schüle (P.A.). Esse mapa, retomado por P. Horden e N. Purcell assim como por N. Vella, representa, na parte mais escura, o conjunto de zonas de onde, em toda circunstância, impossível de ver a terra. É necessária cautela de imaginar que a terra é visível normalmente, a partir de todas as zonas em branco. Esse mapa tem em conta tão somente as restrições relacionadas à geometria da esfera, e de forma alguma as especificidades óticas próprias à transparência do ar. A visibilidade ordinária ultrapassa raramente 20 milhas náuticas (um pouco menos de $40 \mathrm{~km}$ ) no verão.

Não restam menos que algumas costas, como as da Albânia, que são visíveis, durante o bom tempo, a uma distância de 50 milhas e algumas montanhas como a de Cefalônia ou de Leocádia, que podem ser vistas do norte e do oeste a uma distância de 80 milhas. Inversamente, apesar da existência de picos de 3000 metros, a costa dos Alpes Marítimos, de modo geral, não é visível a uma distância superior a 20 milhas. A natureza de suas encostas e de suas regiões interiores permite a orientação, a partir de distâncias que podem ser relativamente importantes, mas que variam consideravelmente e são geralmente muito inferiores às dos padrões teóricos. Assim como as cartas náuticas modernas, os Périplos dos Antigos mencionam escrupulosamente as montanhas que são pontos de referência, tanto para a identificação de seções inteiras de costas quanto para a navegação visual. Por essa razão, nós temos reproduzido em nossas cartas

Heródoto, Unifesp, Guarulhos, v.4, n.1 - 2019.1. p. 327-394

DOI: 10.34024/herodoto.2019.v4.10124 
as montanhas mais significativas à navegação em alto mar. Uma costa ou ilha baixa são armadilhas, ao ponto de que muitas ilhas baixas terem sido batizadas de Planasia, não porque fossem planas, mas do verbo grego planaô (errar), devido à reputação dessas ilhas de enganar navios (Moret, 1977). Uma costa elevada é, ao contrário, um marcador e um guia. Não apenas alguns lugares são visíveis de longe, como à medida que nos aproximamos, podem ser percebidos os detalhes do recorte da linha do horizonte, que se tornam reconhecíveis em quadros específicos, incluídos na memória dos pilotos. Ao contrário das Instruções Náuticas francesas, o Portolano Del Mediterraneo, publicado pelo Istituto Hidrografico della Marina integra, de forma bastante conveniente, o desenho do horizonte, e, até mesmo na época do GPS, a maior parte dos navegantes costeiros prefere a representar de forma sistemática os contornos terrestres.

A partir do mar, as particularidades do traço de uma costa tal qual se tira de um mapa são geralmente invisíveis. Um cabo tão importante como o Cabo Matapão (Tênaro), por exemplo, é invisível quando visto do mar para quem vem do sul. Os cabos tais como se apresentam aos marinheiros são identificáveis, mais comumente, apenas de perfil, ou do alto mar, se apresentam um recorte bem incomum ou apresentam um perfil notável, do qual testemunha, desde a Antiguidade, a toponímia marítima. Muitos caminhos são chamados "testa de carneiro" (do Grego Criu Métopon), outros são chamados de "joelho de velha". Em contrapartida, do mar, a terra se reduz a uma linha irregular e cinza do horizonte que esmaga todos os planos e de onde só se destacam os objetos claros e de perfil particular na linha do horizonte, quando não desaparece sob a névoa.

O Conjunto dessas particularidades constitui as conhecenças que, estritamente falando, são elementos de orientação e de referência infinitamente mais precisos que o plano de uma costa. Eles permitem a identificação de um lugar. Convenientemente alinhados, fornecem uma rota infalível, mesmo no meio do pior labirinto de cardumes de baixios marítimos: Políbio (1.47.1-3) descreve o auxílio prestado por um comandante cartaginense chamado Hannibal Rhodios que entrou no Porto de Marsala à vista da frota romana que margeava o porto : "Graças aos conhecimentos adquiridos por sua experiência, nos diz, ele seguiu marcos de referência através dos recifes (aflorados ou submersos). De fato, uma vez a travessia feita, da forma descrita, ele colocou a proa sobre a torre da orla, como se tivesse vindo da Itália, a fim de alinhar sua rota à sucessão de torres da cidade que estavam voltadas em direção à África. E é a única maneira embocar facilmente pela entrada do porto com o vento favorável"

O homem pode, com efeito, ajudar a natureza, e a maioria das conhecenças são de origem humana. Os inúmeros santuários construídos durante a Heródoto, Unifesp, Guarulhos, v.4, n.1 - 2019.1. p. 327-394

DOI: 10.34024/herodoto.2019.v4.10124 
Antiguidade e a Idade Média, erguidos sobre os cabos (Gambin, 2003; Vella, 2004) não tinham quase nenhum interesse aos caboteiros que viam esses cabos de perfil. Eles eram, ao contrário, essenciais àqueles que vinham de alto mar e, sem dúvida, é esse o sentido de sua menção sistemática nos Périplos. Se eles possuíam de fato uma vocação cultual, possuíam também um papel marítimo essencial.

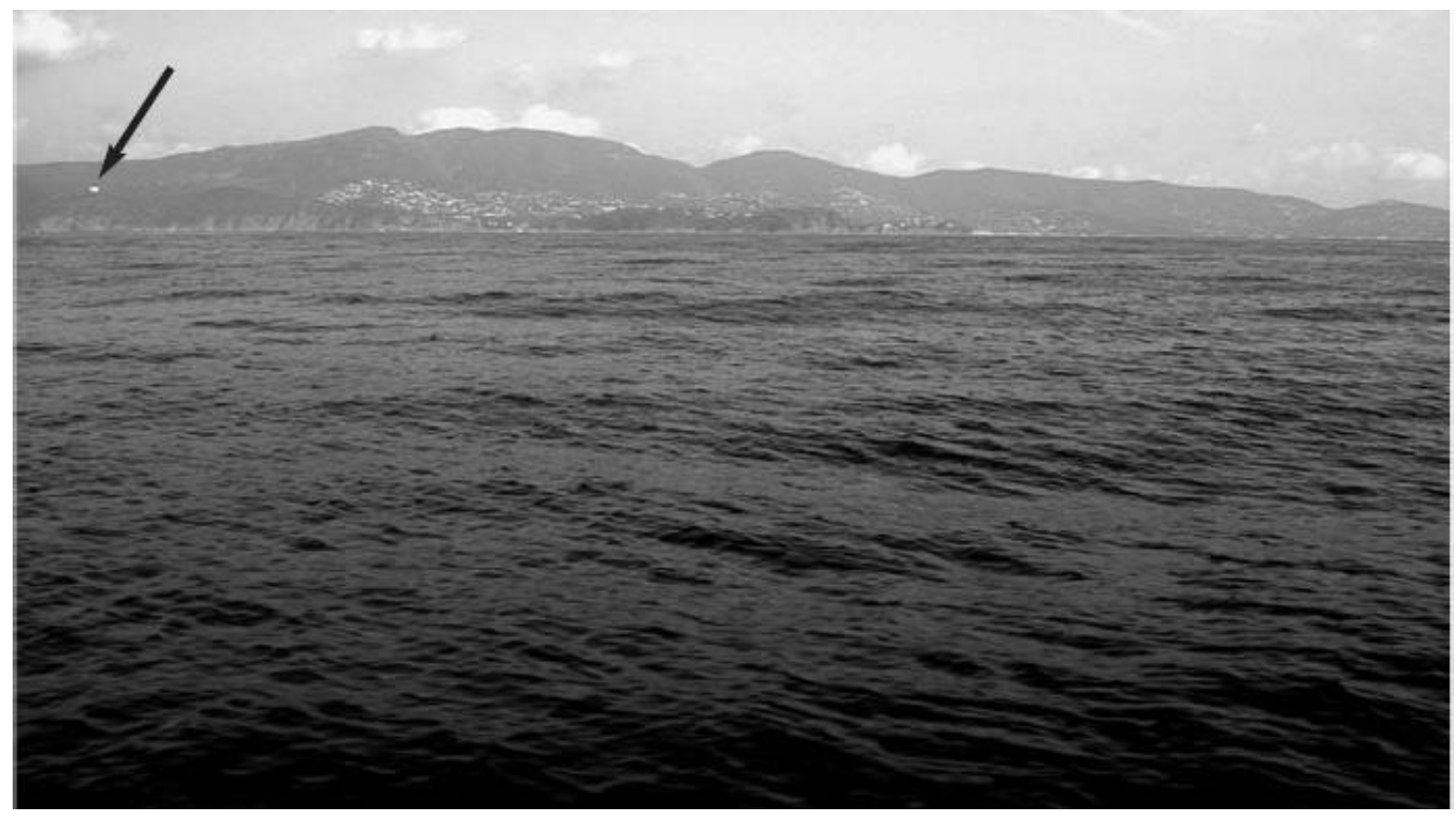

Fig. 11. A terra vista do mar: o Cabo Cavalaire (Var, photo P.A.). Pode-se notar o achatamento dos planos e a dificuldade para se distinguir do mar, um cabo na paisagem que o rodeia. Em contrapartida, é possível reconhecer um perfil no horizonte, mas, sobretudo, a lisura da construção branca à esquerda na imagem, no fundo mais escuro da vegetação.

Inúmeras redes de torres (Corré, 2004) foram erigidas, seja para permitir manobras, tais como aquelas que ritimavam as viragens de bordo na travessia entre Abydos e Sestos (Estrabão: 13.1.22), complicadas pela interação de correntes, ou para marcar uma costa, como a rede de torresconhecenças construídas pelos marselheses ao longo das costas inferiores de Camargue e Languedoc (Estrabão: 4.1.8). Mas, seja de origem natural ou não, a conhecença existe senão pela consciência do homem: o bom navegante era aquele que, como Hannibal Rhodios, tinha notado e percebido seus traços.

\section{O contexto humano: política, tecnologia, savoir-faire}

Tanto quanto ou ainda mais do que as condições naturais, as condições políticas são suscetíveis de modificar as rotas de navegação. Este fenômeno foi posto em evidência na Idade Média (Petti- Balbi, 1996: 272-3). A

Heródoto, Unifesp, Guarulhos, v.4, n.1 - 2019.1. p. 327-394

DOI: $10.34024 /$ herodoto.2019.v4.10124 
necessidade de evitar zonas inteiras, ou de aportar em pontos específicos, em condições determinadas por tratados, desempenharam um importante papel. À escala de um longo período - mais de 1000 anos entre o período arcaico, durante o qual começou a ser construída a memória coletiva do Mediterrâneo no espaço-tempo, e o fim do Império Romano - que tomamos em consideração, e particularmente nos cinco séculos anteriores à era cristã, aos quais se sobrepõe o essencial da nova documentação que levantamos, é evidente que o contexto político não parou de evoluir, e que o Mare Nostrum nem sempre foi o canal comum que descreve no século II d.C. o reitor Aelius Aristide, em seu Elogio de Roma. As redes e os centros do comércio mediterrâneo permaneceram em evolução, a despeito de constantes itinerários fortes. Certas relações diretas, como aquelas registradas por nossas fontes entre Marselha e Igilgili (Jijel), na Numídia, remontam provavelmente ao período de esplendor de Marselha, antes que o desenvolvimento de Narbona não a tornasse porto de referência da costa mediterrânea da Gália. Por isso, essa rota norte-sul, descrita no Liber de Existencia Riverianum, é bastante presente na Idade Média, embora deslocado algumas dezenas de quilômetros, para melhor alcançar Bugia (na atual Argélia), independente do papel de Marselha. Não importando qual tenha sido a evolução de sua frequentação, difícil de apreciar, as altas rotas marítimas, que parecem ter se reduzidas a relativamente poucos itinerários, parecem, em grandes linhas, terem se mantido. Mesmo que seja inegável que novas bacias de consumo, tais quais poderiam ser a aglomeração romana durante o Império, puderam conduzir à emergência de novas rotas, o confronto entre os dados do corpus documental antigo com os registros fornecidos pelo período imperial sugere que as rotas antigas não caíram em desuso, fossem marítimas ou costeiras.

O impacto do contexto político foi importante nas práticas comerciais e nas rotas. Nas altas rotas marítimas, porém, parece ter sido moderado, tendo em vista os objetivos comerciais. Mesmo a pirataria, ainda que analisemos esse fenômeno pouco conhecido nos detalhes, mas que aparenta ter sido particularmente litorâneo, provavelmente não exerceu influência maior sobre as travessias em alto mar. Os dados tecnológicos são hoje melhor conhecidos. Eles são também, em teoria, mais determinantes. A arte da navegação e a arquitetura naval determinavam, com efeito, o que era materialmente possível diante de determinadas condições naturais. Elas são o limite imposto, até certo ponto, ao homem pela natureza. Quando as exigências humanas necessárias para ir de um ponto $\mathrm{A}$ a um distante ponto B, para transportar passageiros, uma mercadoria ou um exército, é necessário primeiramente saber ir e, em seguida, poder fazê-lo. Se os ventos dominantes se opõem a isso, é necessário saber encontrar meios técnicos de ir contra o vento, seja encontrar uma rota alternativa.

Heródoto, Unifesp, Guarulhos, v.4, n.1 - 2019.1. p. 327-394

DOI: 10.34024/herodoto.2019.v4.10124 


\section{O Navio}

Os historiadores da Idade Média nos têm mostrado que o impacto das pretendidas "revoluções" tecnológicas tem sido geralmente mais modesto na realidade da navegação. Com efeito, sabe-se hoje (Petti-Balbi, 1996: 272) que a prática de navegação no Mediterrâneo foi pouco modificada pelas descobertas tecnológicas (bússola, astrolábio, ampulheta, cartas náuticas ou mesmo leme de popa). A tecnicidade crescente dos instrumentos da navegação, e mais ainda a sua presença crescente junto aos terrestres, abriram, ao mesmo tempo que novos projetos, novos espaços de navegação, no fim de um processo que levou quase dois séculos a amadurecer, e do qual quase não restam mais dúvidas hoje, que foi o efeito de uma evolução interna da Idade Média, estrangeira às tradições escolásticas. Assim, as práticas de navegação não sofreram profundas mudanças e não parecem ter desempenhado um papel determinante na reconquista da navegação em alto mar.

\section{A tonelagem dos navios antigos}

Entre as particularidades possíveis da marinha antiga, figura aquela da tonelagem média relativamente alta, em comparação às frotas da Antiguidade Tardia e da Idade Média. No debate sobre a originalidade ou não - da navegação antiga em comparação à navegação medieval, melhor documentada, sobre o traçado de suas rotas e de tempos de percurso, a questão da tonelagem dos navios é regularmente evocada. Os defensores da relevância absoluta do modelo medieval durante toda a navegação pré-moderna, sem negar a existência de unidades grandes e muito grandes, tendem a fazer disso uma exceção, e a enfatizar que o aumento da tonelagem seria um fenômeno bem efêmero, próprio do período republicano e às frotas de aprovisionamento (Parker, 1990: 340-2; Parker 1992a: 26; Mc Cormick, 2001: 95). Para além de frotas relacionadas com ao abastecimento de Roma, não há dúvida que uma parte importante, senão essencial, do parque marítimo era composto de pequenos barcos costeiros (Parker 1984; Houston 1988; Parker 1992b; Horden-Purcell, 2000: 137-143; Reynolds, 1996: 126-127). A aparente redução na tonelagem na Antiguidade Tardia, desse ponto de vista, seria não mais que um retorno à norma.

A despeito de seu caráter bastante fragmentário, e das numerosas incertezas ligadas ao detalhe de sua interpretação, o Papyrus Bingen 77 (Heilporn, 2000), um registro das entradas em um porto não especificado

Heródoto, Unifesp, Guarulhos, v.4, n.1 - 2019.1. p. 327-394

DOI: $10.34024 /$ herodoto.2019.v4.10124 
do Delta, parece confirmar o predomínio de pequenas unidades, designadas como akatoï, pequenos costeiros de propulsão mista (Rouge, 1966: 348; Casson, 1971: 159-160; Heilporn, 2000: 342-343). É possível avaliar a tonelagem de nove dos doze navios mencionados. Dois terços deles têm uma capacidade de carga entre 1000 e 2500 artabes $^{10}$, ou seja, 10 ou 14 toneladas para os menores e de 26,4 a 35,3 toneladas para os maiores. Dois navios ${ }^{11}$ tinham um porte de 7000 artabes, entre 75 e 100 toneladas. Um deles podia comportar 2500 ânforas e pertencia à categoria dos navios "médios" de capacidade entre 1000 e 10000 ânforas ${ }^{12}$. Um terceiro, atribuído à ligação com Óstia, é um navio de 22500 artabes, ou 238 a 318 toneladas. Se desconsideramos o grande cargueiro de Óstia, que retorna vazio, em direção ao leste, para levar em conta não mais que os dois navios de capacidade média, os seis pequenos costeiros, todos eles, representam uma capacidade de carga total de 11.000 artabes, inferior aux 14.000 artabes, por baixo, que representam no total dois navios "médios", e que não correspondem eles mesmos a menos que dois terços do carregamento máximo do navio de Óstia...

Se este documento confirma, sem surpresa (especialmente para um período do ano - provavelmente o verão, data de retorno dos navios da frota de aprovisionamento - que tradicionalmente é o de menor atividade à Alexandria), que os pequenos navios de cabotagem eram a maioria das unidades envolvidas no transporte comercial, mesmo em uma distância média- o que nunca devemos esquecer - ele também incita a moderar alguns excessos atuais e relativizar o alcance em termos de volume de carga, e mostra que sobre linhas comparáveis de trocas à média distância, embora em menor número, os navios de médio porte são os meios de transporte de mais da metade de todos os volumes comerciais, e que os grandes navios não eram excepcionais.

Os estudos mais sérios consagrados à tonelagem dos navios da Antiguidade (Wallinga, 1961; Casson, 1971: 170-173; 183-200; Pomey-

${ }^{10}$ Medida de tonelagem seca do Egito Antigo, hoje ardeb, equivalente à 5,62 alqueires americanos.

${ }^{11}$ Heilporn 2000, 347 considera a tonelagem de uma das duas unidades, um navio de "Anémourion" (Anamur), como desconhecido do escriba. A menção "o mesmo ..." parece-nos direcionar ao navio cuja menção precede aquela deste, reputado ter uma capacidade de 700 artabes, no mínimo para 2500 ânforas.

12 Pomey-Tchernia 1978 234-235, 1000 ânforas correspondem a um porte em peso de cerca de 50 toneladas. Cem toneladas correspondem a 7000 artabes se adotarmos o alto valor do artabe (Heilporn 200, 352-3). Um navio de 2000 ânforas era tomado como a norma de um contrato, pelo jurisconsulto Paulo (Labeo, Pith. A Paulo epitomat., 1 [= Dig. 1.14.2.10.2]), e o texto permite imaginar as possibilidades de sobrecarga em comparação com o calibre teórico. Díon Cássio 56.27.3 evocando legislação de Augusto sugere que a capacidade de 1000 ânforas marcava o limite entre as pequenas e médias unidades.

Heródoto, Unifesp, Guarulhos, v.4, n.1 - 2019.1. p. 327-394

DOI: 10.34024/herodoto.2019.v4.10124 
Tchernia: 1978) levam a conclusões similares. As fontes literárias que, sob o nome de "myriaphores" ou "myriagogues" designam navios capazes de transportar pelo menos 10.000 ânforas, mostram claramente que as unidades de uma tonelagem útil igual ou superior a 500 toneladas constituíam, ao mais tarde, à época da guerra do Peloponeso, um elemento essencial, senão majoritário em número de unidades, de frotas no Mediterrâneo. De seu lado, os dados epigráficos e os estudos dos naufrágios mostram que as unidades de uma capacidade de carga entre 100 e 300 toneladas eram largamente recorrentes no final do século IV. Devemos nos abster de qualquer extrapolação quanto às estatísticas da tonelagem no período. Ela é, primeiramente, relacionada à natureza da documentação: os barcos naufragados anteriores ao fim da República romana são, em efeito, sensivelmente menos numerosos, e a natureza de seu carregamento não permite obter informações claras sobre a sua tonelagem. Por outro lado, as inscrições das honrarias dedicadas aos doadores de trigo no mundo grego egeu, em que se baseia L. Casson, se inscreve em uma faixa cronológica bastante limitada que não mantém com a tonelagem do navio nenhuma relação estrutural ( $c f$. quadro 01).

A Lei de Thasos (IG XII Suppl. p. 151, n 348 et SEG, XVII. 417) da segunda metade do século III a.C. é extremamente interessante. Primeiro porque ela é anterior ao boom sem precedentes do comércio marítimo mediterrâneo que ocasionou a "Paz de Apameia" (188 a.C.), em seguida porque ela nos ensina que as unidades de uma capacidade inferior a 80 toneladas eram simplesmente interditadas do acesso às instalações portuárias da cidade, doravante, elas estavam divididas em duas bacias, uma das quais era reservada às unidades de mais de 130 toneladas. Toda uma série de textos nos mostra, pelo contrário que, sob o Império Romano, é possível distinguir três categorias de navios: aqueles de menos de 68 toneladas, considerados inaptos às operações comerciais de alguma escala, aqueles de 68 a 340 toneladas, e os com mais de 340 toneladas. Se esses textos não nos permitem estabelecer uma estatística das capacidades de carga, eles mostram claramente que os vetores considerados normais do comércio a grandes distâncias avolumavam mais de 70 toneladas e que toda tonelagem inferior era julgada fora das normas do comércio, e dedicado somente à distribuição. A frota comercial do Mediterrâneo se mostrou comparável à frota com a qual Cristóvão Colombo atravessou o Atlântico. A maior unidade dessa frota, Santa Maria, pesava cerca de 120 toneladas (Mc Cormick, 2002: 96).

Nada nos autoriza a afirmar (Casson, 1971: 190; Meijer, 1986: 189) que a tonelagem média de um navio de carga romano era de 300 toneladas. Não há dúvidas que unidades de 300 toneladas ou mais existiam desde o século 
$\mathrm{V}$ a.C. Que ela tenha sido, em qualquer período, uma norma, resta a ser estabelecido. E se havia uma norma, qual seria ela? Uma norma estatística embasada no número de unidades faria aparecer, indubitavelmente, o domínio das unidades pequenas, mas se pensarmos em termos de volumes e valores transportados, a despeito de seu número, elas se tornam minoritárias, de quantidade insignificante.

De modo geral, não se pode negar que a tonelagem e as rotas mantêm ligações estreitas. Já foi enfatizado para outras épocas, a importância do papel do crescimento da tonelagem dos navios no desenvolvimento das navegações em alto mar, menos fragmentadas, e geradoras de tempo de percurso prováveis, não somente por serem atalhos, mas por propriamente mudarem de escala (Petti-Balbi, 1996: 286; Melis, 1979: 114-116). Pode-se, contudo, questionar se não é preciso inverter os termos da afirmação e considerar o aumento da tonelagem como uma consequência do desenvolvimento das relações diretas entre pontos distantes, e não como sua causa. $\mathrm{O}$ aumento da capacidade de carga dos navios traduz, de início, a especialização de trocas de grandes volumes entre pontos longínquos. Ao fim da Idade Média, o desenvolvimento das unidades de grande tonelagem foi menos relacionado à pesquisa de qualidades náuticas próprias que à emergência de novas práticas e interesses comerciais, diferente daqueles que se conectavam à cabotagem e aos navios costeiros.

Quadro I - Capacidade de carga dos navios antigos (de acordo com Pomey-Tchernia 1978, Casson 1971, 171-200 e Heilporn 2000, 347; 352353).

\begin{tabular}{|l|l|l|}
\hline Destroços ou fonte & Data & $\begin{array}{l}\text { Peso estimado (em } \\
\text { toneladas) }\end{array}$ \\
\hline Albenga & Início do século I a.C. & $\begin{array}{l}450 \text { (escavadas), ou } \\
500 \text { a 600 } \\
\text { (Pommey - Tchernia) }\end{array}$ \\
\hline Giens & Início do século I a.C. & $400-450$ \\
\hline Ilha das correntes & s.d. & 350 \\
\hline $\begin{array}{l}\text { Atenas (IG II }{ }^{2} \text { 845, cf } \\
\text { SEG XVI 71 }\end{array}$ & 208/207 a.C. & $\begin{array}{l}330, \text { fretado por um } \\
\text { Etoliano }\end{array}$ \\
\hline Mahdia & 100-50 a.C. & $\begin{array}{l}230-250 \text { (Pomey). Ao } \\
\text { menos 320 (Casson) }\end{array}$ \\
\hline $\begin{array}{l}\text { Egito (P. Bingen 77,9- } \\
\text { 10) }\end{array}$ & século II & $\begin{array}{l}238-318 \text { (navio } \\
\text { cerealista que fazia } \\
\text { ligação com Óstia) }\end{array}$ \\
\hline Marzamemi & Século III & Mais de 200 \\
\hline Torre Sgarrata & Fim do século & Entre 170 e 250 \\
\hline
\end{tabular}

Heródoto, Unifesp, Guarulhos, v.4, n.1 - 2019.1. p. 327-394

DOI: 10.34024/herodoto.2019.v4.10124 


\begin{tabular}{|c|c|c|}
\hline Saint-Tropez & Século II & 200 \\
\hline Atenas (IG II 408) & $\begin{array}{l}\text { Aproximadamente } 330 \\
\text { a.C. }\end{array}$ & $\begin{array}{l}\text { 165, navio fretado em } \\
\text { Heracleia }\end{array}$ \\
\hline Atenas (IG II² 400) & 320/319 a.C. & 165 \\
\hline $\begin{array}{l}\text { Egito (P. Bingen 77,23- } \\
24)\end{array}$ & Século II & $\begin{array}{l}125 \text { (2500 ânforas) ou } \\
100 \text { em sobrecarga } \\
\text { (navio proveniente de } \\
\text { Anamur - ou "navio } \\
\text { de Anamur"?) }\end{array}$ \\
\hline I 361) & Fim do sé & $\begin{array}{l}\text { 120, navio fretado em } \\
\text { Torone }\end{array}$ \\
\hline Atenas (IG II² 360) & 325/324 a.C. & $\begin{array}{l}\text { 120, navio fretado em } \\
\text { Chipre }\end{array}$ \\
\hline Atenas (IG II ${ }^{2} 363$ ) & 324/323 a.C. & $\begin{array}{l}\text { 120, navio fretado em } \\
\text { Heracleia }\end{array}$ \\
\hline Atenas (IG $\left.{ }^{2} 398\right)$ & 320/319 a.C. & $\begin{array}{l}\text { 120, navio fretado no } \\
\text { Helesponto }\end{array}$ \\
\hline $\begin{array}{l}\text { Delos (Insc. Delos } 442 \\
\text { A, 100-105) }\end{array}$ & 179 a.C. & 115, Massinissa \\
\hline $\begin{array}{l}\text { Egito (P. Bingen 77, 21- } \\
\text { 22) }\end{array}$ & Século II & $\begin{array}{l}74-99 \text { (graneleiro } \\
\text { proveniente de } \\
\text { Aspendo - ou "navio } \\
\text { de Aspendo"?) }\end{array}$ \\
\hline Éfeso (Syll.8 354) & $\begin{array}{l}\text { Aproximadamente } 300 \\
\text { a.C. }\end{array}$ & $\begin{array}{l}\text { 95, navio fretado em } \\
\text { Rodes }\end{array}$ \\
\hline Delos (IG XI. 4 627) & $\begin{array}{l}\text { Primeira metade do } \\
\text { século III a.C. }\end{array}$ & $\begin{array}{l}\text { 20, navio fretado em } \\
\text { Bizâncio }\end{array}$ \\
\hline
\end{tabular}

Em contrapartida, reduzir, em princípio, as "pequenas unidades" aos navios de cabotagem como geralmente é feito de maneira bastante sistemática (Mc Cormick, 2002: 95-97; Horden-Purcell, 2000: 140; PettiBalbi 1996: 286) é, sem dúvida, exagero. De uma parte, com efeito, a noção de "pequenas unidades" é muito fluida para ser a única pertinente, tendo em conta o estado de conservação das carenas e à curva de crescimento da tonelagem que evolui mais rapidamente que aquela do comprimento da quilha. Pode-se assegurar que, se, entre as pequenas unidades figuram inegavelmente navios costeiros envolvidos em um comércio de redistribuição limitado somente à cabotagem ferista (o que não era necessariamente o caso de todos os navios de cabotagem, como mostra o papiro Bingen 77), a natureza de carregamento de um número de pequenos naufrágios não permite reconhecer unidades empregadas em tal tipo de comércio. Por outro lado, a distinção entre barcos costeiros e navios de Heródoto, Unifesp, Guarulhos, v.4, n.1 - 2019.1. p. 327-394

DOI: 10.34024/herodoto.2019.v4.10124 
longo curso deveria obedecer a normas de concepção particulares, notadamente, mas não sistematicamente, o recurso a sistemas de propulsão mista, bastante comuns no período, como os akatoi ou os actuarieae, ou a concepções de cordames adaptados a condições mais mutáveis.

\section{Capacidade de navegar sob todas as mareações}

Não nos prolongaremos sobre a capacidade das carenas. Mesmo breve, a navegação da réplica do navio helenístico de Kyrénia confirmou o essencial do que é necessário saber em primeira análise: a característica bastante marítima de uma carena e de um cordame pouco velozes, mas capazes de estender uma brisa a picos de 40 nós. A capacidade teórica dos cordames é mais problemática, e a habilidade dos navios antigos de remontar o vento é ainda objeto de inúmeras discussões. Esses navios eram asseguradamente capazes de navegar de outra forma que não por vento traseiro, o que se sabe há muito tempo (Köster, 1923: 177-185; Casson, 1971: 281 sq.; Pryor, 1988: 33-35; Janni, 1996: 410-412; Pomey, 1997). A razão desejaria que a possibilidade dos navios de contornar a remo era a consequência de sua capacidade de ir contra o vento, mesmo em moderadas proporções.

Uma primeira certeza é que eles evoluíam a mareações naturalmente menos favoráveis que à popa rasada ou ao largo. Plínio, o Velho $(\mathrm{HN}$, 2128) evocou uma navegação por um vento ao menos de través: "Com os mesmos ventos, navegamos em direções opostas, escotas alinhadas, embora muitas vezes, durante a noite, navios colidam." A capacidade dos navios antigos de irem contra o vento também é estabelecida com base no testemunho do Pseudo-Aristóteles (MSPS., 7) que descreveu como, transformando a vela quadrada em vela triangular, os marinheiros conseguiam prosseguir contra o vento ${ }^{13}$.

A questão é saber se este tipo de equipamento realmente foi utilizado em navios mercantes e, se neste caso, qual seria seu desempenho. Dispomos, acerca do aparelhamento da Antiguidade, uma iconografia abundante. Porém, nunca, antes do período Bizantino, encontrou-se a vela latina associada aos navios de carga. Esta situação leva-nos a várias conclusões. A primeira é que evoluir sob a vela triangular (e, portanto, contra o vento)

\footnotetext{
${ }^{13}$ Opinião contrária de Basch 1997, que vê aí a descrição de uma manobra de capa de corrente.
}

Heródoto, Unifesp, Guarulhos, v.4, n.1 - 2019.1. p. 327-394

DOI: 10.34024/herodoto.2019.v4.10124 
era para navios de carga de uma situação anormal e excepcional. A segunda é que uma transformação da forma da vela foi necessária.

Nesse nível de análise convém considerar três parâmetros, o ângulo máximo de navegar contra o vento, que varia de um navio para outro, as manobras necessárias a esse tipo de mareação, e a sua comodidade ou não, enfim, as respectivas vantagens e desvantagens de ir contra o vento de acordo com a força do vento e das condições do mar.

A navegação experimental do Kyrénia II mostrou que o barco, com uma vela latina, possuía um desempenho melhor que esse mínimo, já que ele podia alcançar na brisa um ângulo de $60^{\circ}$ do um vento sensivelmente melhor que aqueles dos grandes veleiros do século XIX, que não passavam dos $67^{\circ}$, e aproxima dos Dhow árabes de vela latina, que atingiam um ângulo de 7/4, ou um ângulo de 56 e 15' (Janni, 1996: 411). Com efeito, o problema advém do fato de que a remontada ao vento depende principalmente de como o navio é equipado, o que é infelizmente, o elemento que menos se conhece.

A navegação em bolina, sobretudo se é pouco cerrada, pode ser feita sob dois tipos de condições. A primeira, é a de bolina estabelecida, quando o navio, navegando em bolina, a um cabo determinado, não precisa mudar de direção para chegar ao destino fixado. O aparecimento da bolina, que permite fixar próximo do ponto a extremidade inferior da verga inclinada e enlaçada no eixo do navio, em condições tais que a vela triangular é fixada por um ponto da amura, que aumentando o desempenho convem mais com o bordo longo em bolina folgada do que com o bordejo (Pomey, 1997: 86). Os brióis que facilitam, até certo ponto, a mudança da forma da vela no vento fraco, mostram, por sua parte, seus limites na brisa (Luciano, História verdadeira, 1.1). Eles são praticamente exclusivos de velas triangulares específicas, que poderíamos equipar no lugar da vela quadrada, e que continuam teoricamente possíveis em cordames sem brióis.

O segundo tipo de navegação à bolina é o bordejo. Trata-se de virar de maneira bem regular de bordo, de maneira que o resultado da rota em ziguezague criada por esta manobra corresponda a um ângulo inferior ao ângulo máximo de navegação contra o vento autorizada pelas capacidades específicas do navio. A prática do bordejo era aliás bastante conhecida (Virgílio, Eneida 10.831 sq.) e, muitas vezes, era necessária para sair de um golfo. Em longas distâncias, ela exigia repetidas viragens de bordo que podiam se operar de duas maneiras: vento contrário ou orçado (cambar). 
A primeira manobra, comum a cordames modernos, era muito arriscada em barcos de vela latina e mais ainda em cordames quadrados, e tornouse normal apenas com os Lugres. Com efeito, o navio devia dispor de bastante espaço para poder orçar até ultrapassar a direção que sopra o vento e abater até encontrar do outro lado um ritmo compatível com a sua capacidade de remontagem. Este tipo de viragem de bordo é condicionada pela capacidade de aplanar significativamente a vela para melhorar o ângulo de navegação contra o vento, e por uma arqueação fraca. Caso contrário, inevitavelmente, o navio deixa de girar. Se a manobra é bem sucedida, a verga não é rodada completamente em torno do mastro e a vela desfralda, sobre um dos lado, de modo a formar dois bolsos de uma parte à outra do mastro, quando ela se encontra à barlavento do mesmo, com um rendimento mais baixo do que o outro lado.

Por todas essas razões, a manobra mais comum para virar o bordo consiste em virar "lof pour lof », ou seja, para ir de um ângulo determinado em relação ao vento a um ângulo identico sobre o outro lado, um círculo quase completo, passando pelo vento posterior, percorrendo ao vento de popa nesta passagem a distancia mais curta na direção oposta à aquela desejada. Sob verdadeiro lugre latino, a manobra é bem simples quando da passagem da direção que sopra o vento, a verga é levada para a vertical e as escotas soltas. A vela se põe a tremular como bandeira, e o punho da escota sendo levado pelo vento ao eixo da proa. Basta então ajustar a escota e reinclinar a verga para terminar a viragem de lado. Ela se torna longa e fastidiosa sobre um cordamento quadrado. Sobre os cordames quadrados do séc. XIX, ela toma mais de uma hora. Podemos especular as pricipais fases de um cordame montado em triângulo. A vela deve, de início, ser reduzida para ser ajustada em triângulo na outra extremidade da verga, ao mesmo tempo em que a verga é recolocada na horizontal e reorientada perpendicularmente ao eixo de progressão do navio. Essa manobra se opera progressivamente, entre à bolina e à popa rasada. Para facilitar a manobra e limitar a progressão à popa rasada, devemos fazer abater o navio, estabelecendo um velame reduzido sobre o artemo, e esconder todas as velas para restabelecer progressivamente a vela principal, primeiro em quadrado, a verga estando gradualmente batida, até vir para o eixo de progressão do navio, depois abaixada ao mesmo tempo que a vela é enrolada em triângulo. As superfícies de velas implicadas e a arqueação importante parecem ter limitado esta prática ao vento fraco. Em contrapartida, não é excluído que, ao preço de tomadas de molejas sólidas, os navios helênicos, desprovidos de brióis e consequentemente menos cobertos de adriças, puderam, pelo menos, para o menos pesados entre eles, virar como os equipamentos triangulares comuns. 


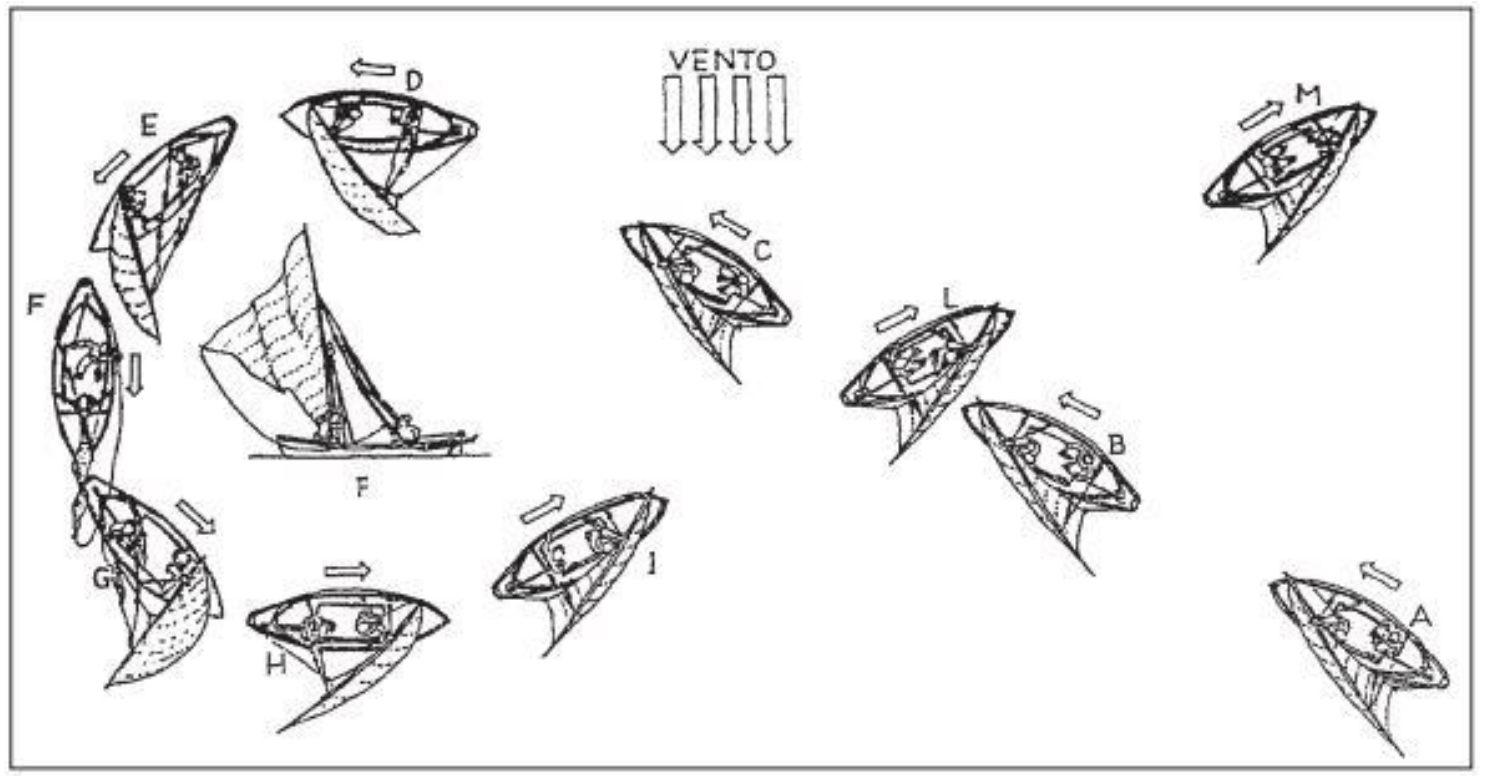

Fig. 12. A viragem em orçada (lof pour lof) sob vela latina, a partir de S. Ricca Rosellini 1988. Para virar de lado sob a vela latina, o navio deve passar pelo vento traseiro e pôr a vela em bandeira para fazê-la alterar de lado.

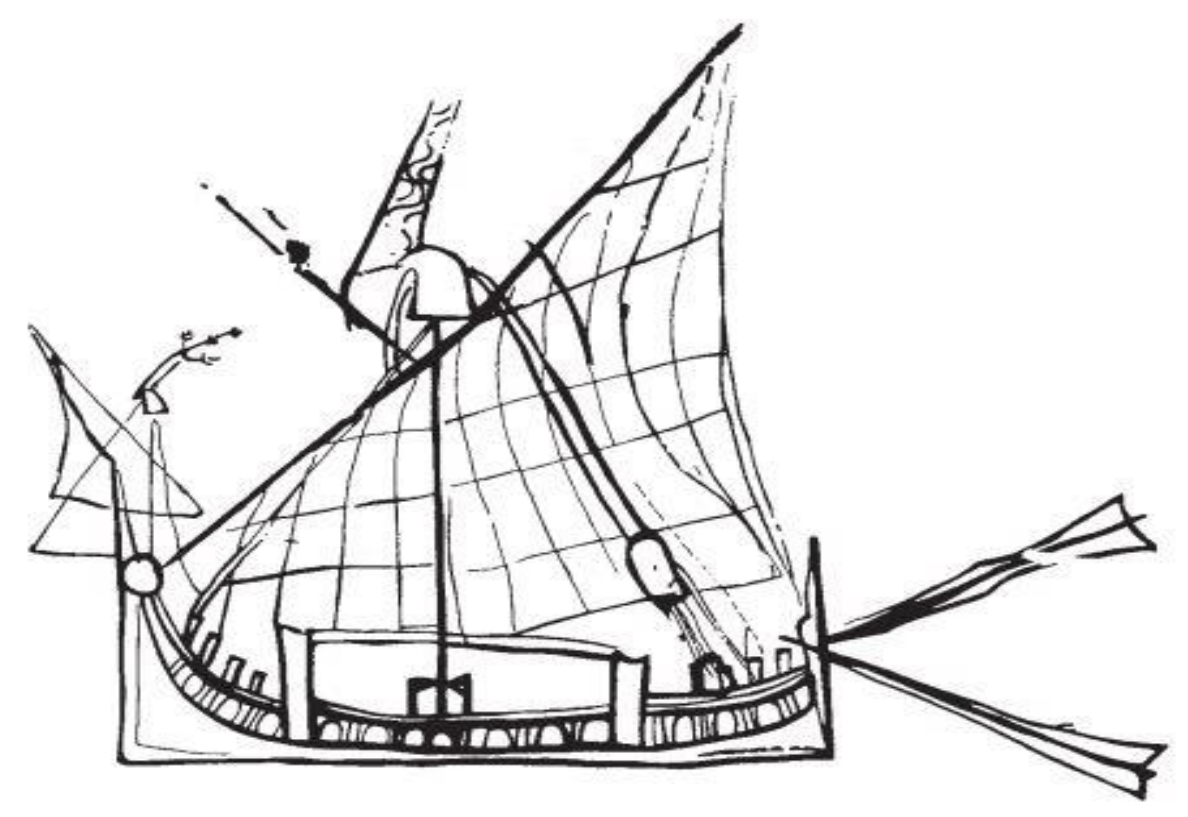

Fig. 13. Uma das mais antigas representações da vela latina: a "feluca do Kellia" (600630 d.C.), de Basch 1997, fig. 1. A mais antiga representação da "vela latina" é dois séculos mais antiga (Mosaico de Kelenderi). Ela procede como alguns já supunham, de uma alteração da vela quadrada em vela triangular, mas já apresenta os traços específicos de um equipamento latino, notadamente as linhas de moleja (Pomey 2005). 


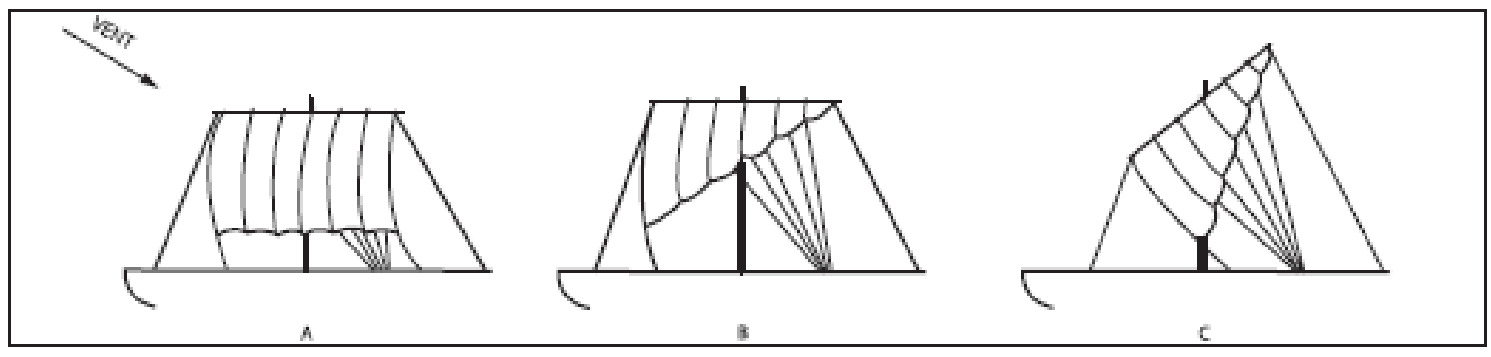

Fig. 14. O processo de transformação de uma vela quadrada em uma vela triangular, de acordo com L. Casson. Este dispositivo, do qual P. Pomey propõe uma descrição mais precisa, é comprovado desde o século II a.C a diante (Basch 1997; 2001).

Ao contrário da opinião generalizada (McCormick, 2001, 408 e 1992 Pryor, 33-5), a verdadeira vela Latina, em si, não garantia melhores condições de subida ao vento do que as autorizadas pelos equipamentos quadrados temporariamente, carregado ou erguido em vela triangular: ela facilita as manobras de bordejo e é adequada à navegação costeira. Sua generalização em detrimento da vela quadrada (que os navios jamais abandonaram até o desaparecimento de vela) destaca, sem dúvida, a passagem a uma prática predominante de cabotagem.

Reconhecemos, de acordo com P. Janni (1996, 409-413) que, considerando todos os parâmetros, incluindo a deriva induzida por estes andamentos, os navios de carga da Antiguidade não deviam se sair muito melhor na rota real do que de través, e que à exceção de circunstâncias muito peculiares, seja próprias à navegação costeira (dobrar um cabo, sair de um golfo ou atravessar uma ravina), seja na navegação em alto-mar, quando um bordo de bolina conduzia sem bordejar na direção procurada, o recurso às mareações de bolina, mesmo pouco cerradas, devia ser bastante excepcional, incluindo por razões de conforto: logo que o vento refrescava e que o mar escavava-se, o navio inclinava sobre um bordo, batia na onda, submetendo a carga a movimentos incessantes, e tendia a embarcar água. De acordo com um antigo dito acerca do bordejo dizia "duas vezes a rota, três vezes o tempo, quatro vezes a pena". Se, sem dúvidas, era possível, em certas condições, remontar vento, as capacidades de fazê-lo não eram tantas que permitissem considerar subir ao vento com um ângulo significativo em longas distâncias. De um lado, a tensão sobre os ovéns tende a separar as peças de viragem ao vento, e o navio tende a fazer água quando cessa de balançar, por outro lado, as carenas antigas, com baixos volumes imersos tinham um limite claro: sua deriva importante à partir do vento de través, desde que o vento refrescasse. Em cabo real, os navios antigos eram sem dúvidas, qualquer outra coisa que que não os campeões em remontar ao vento e eram ainda menos eficientes sobre esse ponto quanto mais o vento estivesse frio. Vimos que, mais a força do vento crescia, mais o leque direções possíveis tendia a aproximar-se do vento de Heródoto, Unifesp, Guarulhos, v.4, n.1 - 2019.1. p. 327-394

DOI: 10.34024/herodoto.2019.v4.10124 
popa, até a resumir-se à fuga sob velame reduzido.

É, pois, necessário adotar uma visão bastante flexível acerca da capacidade dos navios antigos, dependendo das condições em que eram mantidos. É certo que, comumente velejavam ao vento de través e sem dúvidas, em longas distâncias: um grande número de representações figurativas mostra claramente velas reguladas para essa mareação, que era, sem dúvida, uma das mais utilizadas, a julgar pela correlação entre as rotas conhecidas e o mapa de ventos predominantes. Não podemos excluir que, em vento fraco estabelecido [petit temps], nós fomos capazes até mesmo de ir até ângulos modestos contra o vento. Em contrapartida, assim que o vento esfriasse longe da costa, vemos os navegantes fugindo e procurando o vento de popa sem fazer mais perguntas. Mas aqui nós deixamos o campo das rigorosas especificações técnicas para entrar no domínio dos usos, sem os quais os dados técnicos significam pouco.

\section{Aparelho de governação e busca de equilíbrio de barra}

O leme lateral foi considerado por bastante tempo como um arcaísmo escandaloso. É necessário, na realidade, distinguir dois sistemas: o remo, capaz de movimento lateral ou movimentos de ginga, usados para dirigir o navio, que é encontrado em pequenas unidades; e o leme lateral compensado, um aparelho que opera por rotação em torno de um eixo capaz de mudar seu ângulo de incidência. É este último que nos interessa. Destinado ao suplício por gerações de historiadores de navegação, este mal-amado método há muito tempo apareceu como uma fraqueza da navegação antiga. Felizmente, foi possível entender melhor esse objeto essencial (1975,68-71 Rouge; Mott, 1997; Pomey 1997, 87), cuja eficiência foi suficiente para torná-lo o símbolo iconográfico da autoridade e da capacidade de influenciar o curso das coisas. Parece claro à experiência que, sem prejuízo das adaptações necessárias e de acordo competência de seus usuários, sua capacidade não era inferior ao do leme de popa, com o qual tantas vezes é comparado para ser melhor denegrido. Sua principal limitação está, na verdade, em seu ajustamento reduzido. A recente descoberta de um aparelho de direção bastante completo, permitiu estabelecer que ele não excedia um ângulo de $18-20^{\circ} \mathrm{em}$ torno da "barra a zero". Tal limitação supõe evoluções largas; Ela confirma desse fato, se ainda duvidamos, a prática de viragens de bordo (cambar), excluindo praticamente a viragem em vento contrário, e supõe um recurso limitado ao bordejamento. 

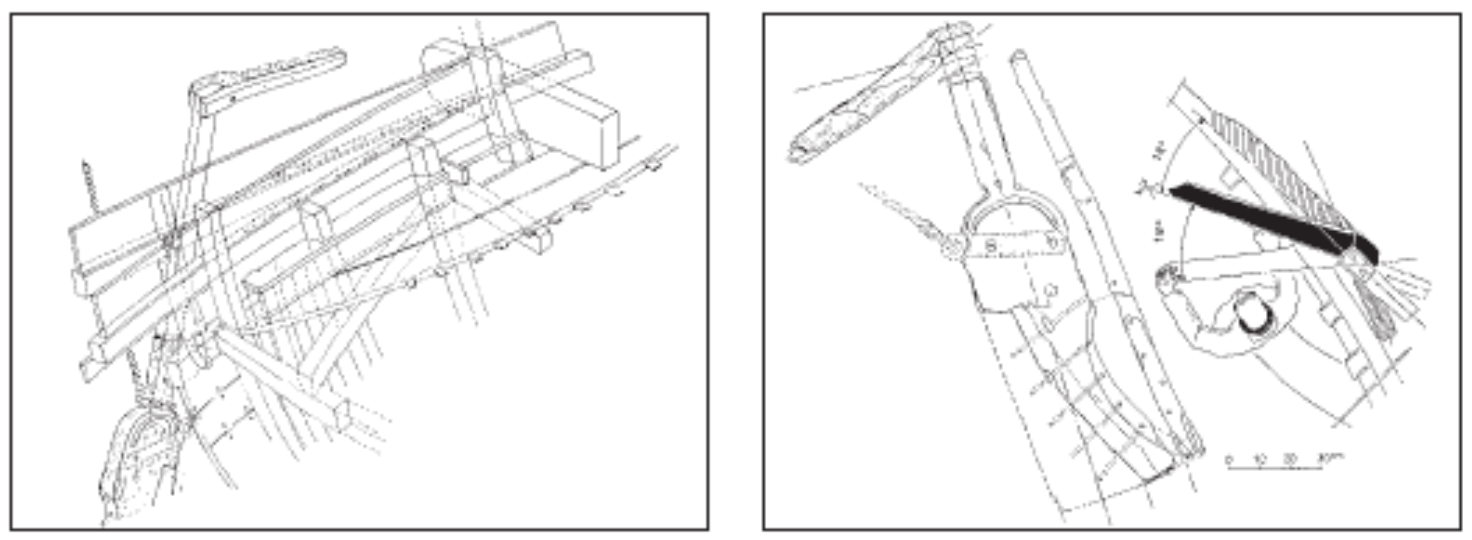

Fig. 15. À esquerda - O sistema de direção encontrado no naufrágio de Laurons 2, de acordo com Gassend 1998, fig. 2. Este dispositivo é um dos mais completos conservados até o presente. À direita - o ângulo da barra reconstituído a partir dos destroços do Laurons 2, de Gassend 1998, fig. 3. Seremos sensíveis ao pequeno movimento da barra.

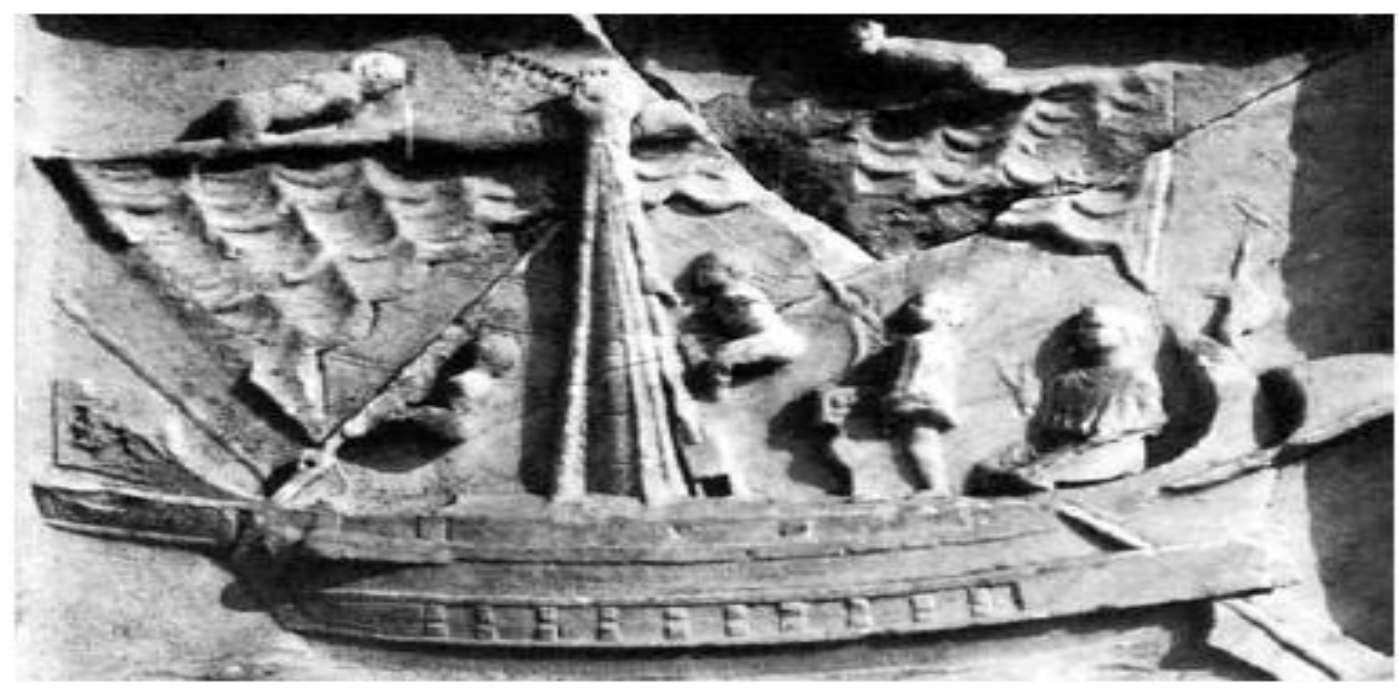

Fig. 16. Relevo do túmulo de Navoleïa Tychè em Pompeia. Este relevo é uma das raras ilustrações de manobra de um navio antigo. A tripulação está prestes a carregar as velas para modificar a forma. Nota-se que o comandante, que evidentemente controla a manobra, não mostra nenhum sinal de esforço sobre a barra (cliché R. Chéné, Centre Camille-Jullian).

O leme de governação compensado antigo parece, no entanto, surpreendentemente fácil de manusear. A iconografia antiga geralmente representa um timoneiro sentado, numa situação em que, ao menos com vento de popa, não produz nenhum esforço especial na barra, e trata-se de um verdadeiro lugar comum na literatura antiga ${ }^{14}$ a oposição entre a representação de um franzino timoneiro à do grande navio que governa.

14 Janni 1996, 421, n.8, cf. Lucien, Nav., 6 ou, ainda, Epístola de Tiago, 3.4.

Heródoto, Unifesp, Guarulhos, v.4, n.1 - 2019.1. p. 327-394

DOI: $10.34024 /$ herodoto.2019.v4.10124 
No entanto, à exceção do vento de popa, a maior parte das mareações faz com que o navio tenha a tendência de bordejar ou abater e impõe ao timoreiro uma compensação permanente ao autobordejamento ou ao autoabatimento, necessariamente esforçante fisicamente sobre grandes unidades, em ausência de sistemas de distribuição de forças. Na hipótese de práticas normais de navegação de través, quiçá à bolina, temos o direito de esperar sistemas que pudessem ter facilitado a tarefa do timoneiro. É no cordame que nos parece mais pertinente buscá-los. O surgimento de dois mastros adicionais parece ter tido o principal objetivo de equilibrar o navio e facilitar tanto a sua evolução e condução pelo leme. Estes dois mastros parecem, de fato, nem sempre terem sido capazes de melhorar significativamente a velocidade das embarcações (que não foi provavelmente uma preocupação central dos navegadores mais antigos) em proporções correspondentes à complexidade que trouxeram. A sua razão de ser principal foi, sem dúvida, outra.

A introdução de um segundo mastro na frente do primeiro é muito antiga e remonta à época etrusca (Casson 1963). Seu primeiro registro, sobre uma galera de combate remonta ao século VI (Pomey 1.997,68), e o navio retratado em "tomba della nave" de Tarquínia, no século $\mathrm{V}$, é a mais antiga evidência da sua presença em um navio comercial. Este mastro, reconhecido como artemo dos textos antigos, tinha uma inclinação ajustável, e desempenhou, sem dúvida, menos um papel de propulsão (sem dúvida real, sobre grandes unidades, das quais ele permitia fragmentar o cordame), e mais um papel de manter o equilíbrio em uma determinada mareação, e foi, como tal, um apoio para a execução de manobras. Mais o abaixamos, mais ele avança em relação ao centro da carena, e mais a vela que ele segura faz abater o navio. Da mesma forma, a pequena vela que é encontrada na parte de trás, perto da popa, vista em muitas representações de grandes unidades, não pode ser considerada como uma vela propulsora: é uma "gangorra", cuja localização, muito para trás, torna o navio ardente e o faz orçar. 


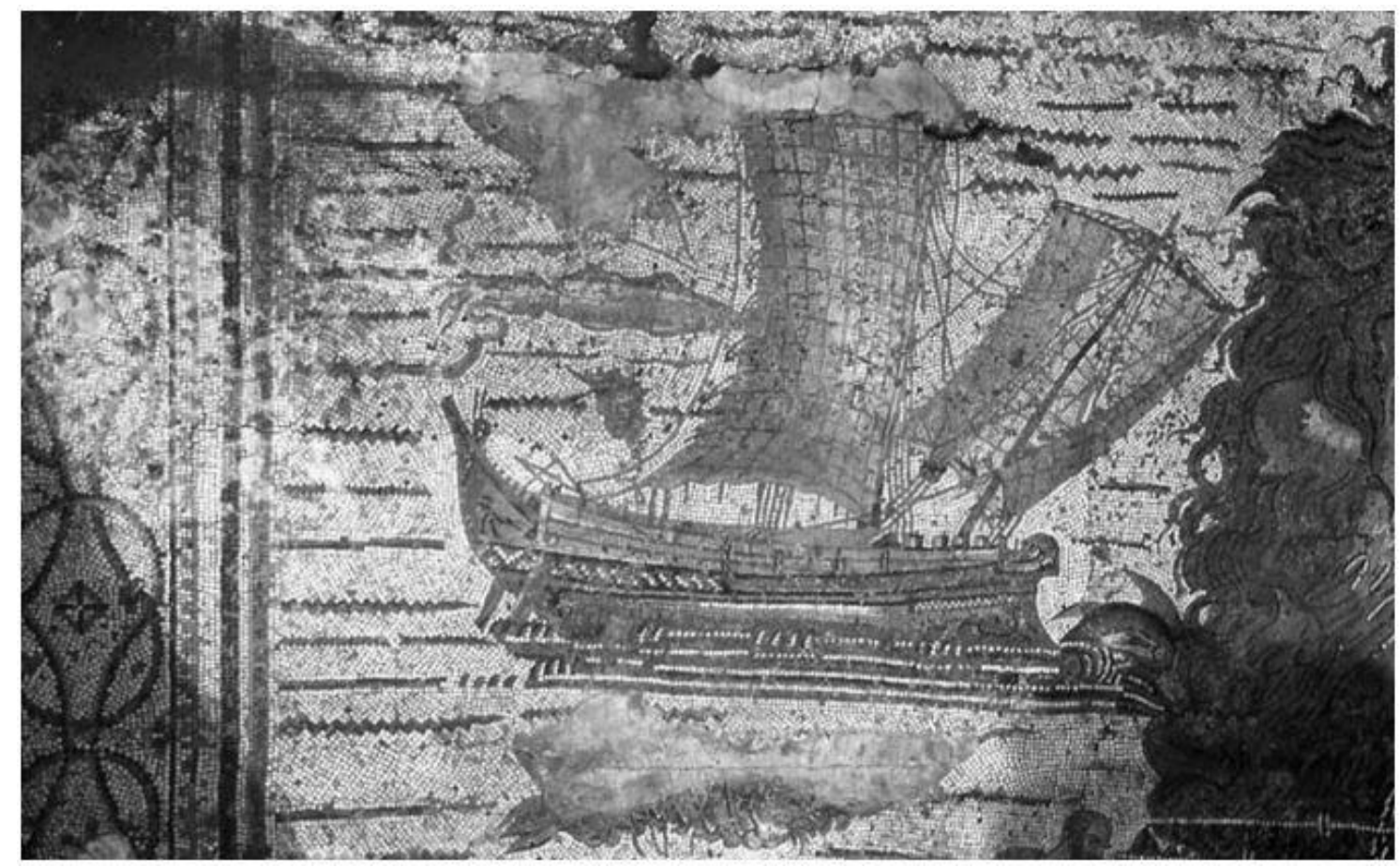

Fig. 17. O artemo no navio do mosaico de Thémétra. Este famoso mosaico, que ilustra um grande transportador do mesmo tipo de destroço da Madraga de Giens mostra, à frente, um artemo equipado com uma vela de superfície equivalente àquela da grande vela. Essa é uma vela propulsora cuja vocação não se reduz à pequena vela de mau tempo, utilizada para fuga, ou a uma vela de equilíbrio destinada a manter o navio na cama do vento. (foto de R. Chene, Centre Camille Jullian).

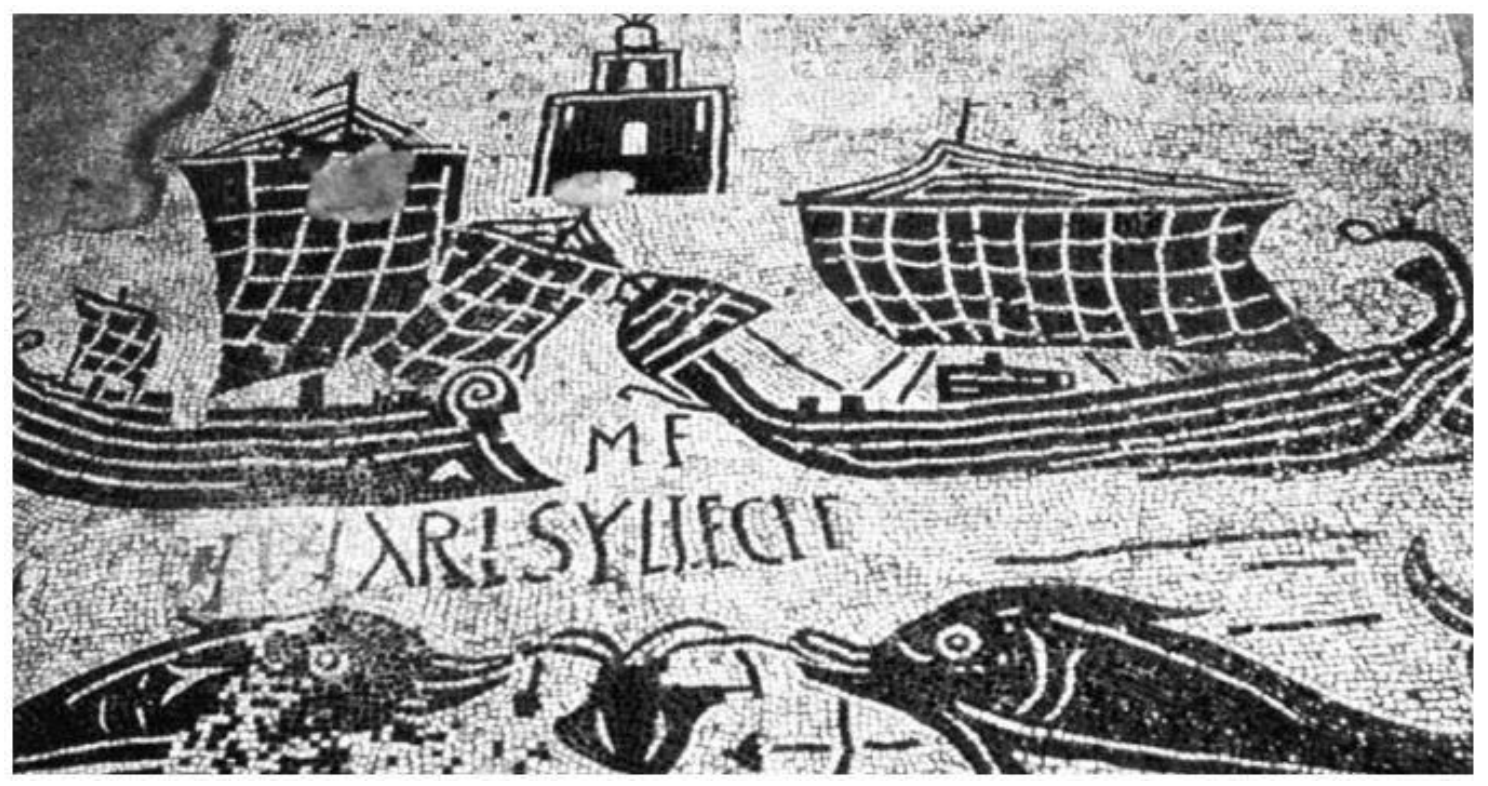

Fig. 18. Navio sob grande vela, artemo e gangorra (Óstia, Fórum de Corporações). A gangorra, localizado bem no fundo, faz o navio bordejar. A pequena vela de artemo, aqui rebaixada para a posição de um gurupés, o faz abater. Eles permitem equilibrar o navio (foto de R. Chene, Camille Jullian-Centro).

Uma vez que um navio evolua sob mareação de vento não favorável, o

Heródoto, Unifesp, Guarulhos, v.4, n.1 - 2019.1. p. 327-394

DOI: 10.34024/herodoto.2019.v4.10124 
desequilíbrio da vela propulsora faz ele abater ou orçar, o que é aliás raramente neutro por natureza, mas tende a ser sempre um pouco ardente ou um pouco mole por causa de sua forma e de sua posição em suas linhas. Ambas as velas adicionais podem ter sido uma resposta para o tamanho crescente dos navios, não tanto para melhorar a velocidade, devidamente ajustada, mas para deixar o leme neutro a todas as mareações, e obter navios mais estáveis, capazes de manterem-se sob uma regulagem determinada das velas, em um ângulo constante em relação ao vento.

\section{Material de bordo e ajudas à navegação}

Para cumprir a rota, ou seja, se movimentar, em condições de ventos e correntes determinadas, de um ponto a outro ao longo de um percurso predefinido, não é suficiente ter navios tecnicamente capazes de executar essa rota, e equilibrados o suficiente para não tentar se afastar. É necessário também ser capaz de garantir que ele pode seguir regularmente a rota traçada.

Não ocorreria à mente de qualquer navegador moderno navegar sem embarcar com ele os instrumentos para se situar acerca da distância percorrida: mapa, bússola de rota e de observação, sextante (hoje colocada na posição de acessório pelo GPS). Mas ao se fazer a lista das ferramentas e documentos necessários a bordo, percebe-se que ela é dramaticamente curta: um livro ou diário de bordo, presente desde época longínqua e onde são assinaladas a rota e os diversos acidentes (Bresson, 2000, 141-149), mas também os detalhes de carga e descarga, sondas de mão, bem atestada em naufrágios e descritos na história naufrágio de Paulo, equipamentos de segurança (incluindo uma ânfora utilizada como âncora flutuante). Mas a primeira surpresa para um contemporâneo é a aparente constante ausência, em navios da Antiguidade, de qualquer equipamento de auxílio à navegação.

Exclui-se, obviamente, a bússola, que é introduzida no período medieval. Retira-se também o astrolábio que, nas suas aplicações marítimas, permitiu calcular com uma aproximação aceitável, a latitude, entendendo-se que as longitudes fossem calculadas com uma precisão aceitável somente a partir do século XVIII. Os elementos teóricos necessários para a sua construção eram conhecidos desde o fim do século III a.C., mas o primeiro autor a descrever precisamente o que poderia ser fisicamente um astrolábio foi Théon de Alexandria, no fim do século IV d.C. Sua filha Hypatia era aluna de Synésios de Cyrène, que aparece para descrever o uso de um astrolábio. Geralmente considera-se que a descrição efetiva de um astrolábio real não

Heródoto, Unifesp, Guarulhos, v.4, n.1 - 2019.1. p. 327-394

DOI: 10.34024/herodoto.2019.v4.10124 
acontece antes do século VI e é encontrada em Jean Philoponos de Alexandria. Em todos os casos, qualquer que seja a data introdução efetiva deste objeto, que foi durante muito tempo apanágio de alguns sábios de alta navegação, trata-se de uma procura em vão a bordo dos navios antigos. Os restos de um complexo mecanismo descoberto ao largo de Anticítera (preço de 1974; Zurcher 2004), durante algum tempo interpretados como uma espécie de astrolábio, fazendo parte do equipamento de bordo, é agora certamente identificado como um relógio astronômico, uma curiosidade científica de grande preço, provavelmente exportada para um rico comprador italiano, e fadado a terminar, a exemplo dos planetários animados de Arquimedes, como curiosidade numa mansão aristocrática ou em um templo na capital. É por esta razão, não mais que um elemento da carga, independente do funcionamento geral do navio. Nenhum naufrágio antigo nos legou entre os objetos de bordo, algum objeto que pareça, de alguma forma, um astrolábio.

Entre as ferramentas tradicionais de navegação poderíamos esperar aquelas que permitiam medir a distância percorrida pelo navio e, a partir disso, a sua velocidade. Elas fazem parte do equipamento básico em todos os navios modernos, e algumas delas, como a barquinha a nós, que de longa data tem demonstrado sua formidável eficiência, juntamente com a sua simplicidade, poderia muito bem ter desaparecido sem deixar vestígios. Por um golpe de sorte excepcional, a ausência de qualquer dispositivo de medição da distância percorrida é de fato assegurada por uma declaração, mais explícita impossível, de Marciano de Héracleia, compilador, no início do século $V$, do Périplo de Menípio de Pérgamo (Müller 1855 568, § 5). De acordo com ele, de fato, " são as práticas usuais (synèthéïa), mais do que qualquer outra invenção técnica (épitechnèsis) que permitem a medição em estádios de uma extensão de água".

O testemunho de Marciano é sem apelo e permite fechar um antigo debate: de que, normalmente, não existia nenhum aparelho capaz de permitir a avaliação da distância percorrida. Tentou-se já reconhecer em um dispositivo descrito no período de Augusto, pelo arquiteto Vitrúvio“15, tomado do estudioso helenístico Hiero, uma espécie de barquinha à hélice, da qual tentou-se mesmo achar traços em um mosaico de Sousse (Foucher 1958). Na verdade, se tratava de um sistema de pás, uma variante do odômetro de Hiero, que ao jogar uma pedra em um recipiente bronze, teria desencadeado um sinal sonoro a cada milha romana percorrida. Sua função, tal como descreve Vitrúvio, é a de uma barquinha, mas não

15 10.9.5-7. Cf. Rouge 1966, 83. Esta passagem de Vitrúvio é considerada suspeita pelos editores, uma vez que incorpora quase que integralmente aquela que imediatamente a precede.

Heródoto, Unifesp, Guarulhos, v.4, n.1 - 2019.1. p. 327-394

DOI: 10.34024/herodoto.2019.v4.10124 
escapou a Leonardo da Vinci que o sistema assim descrito era, em virtude de sua fragilidade, totalmente inadequado para o ambiente marinho. Foi, na melhor das hipóteses, uma curiosidade técnica desprovida de aplicações práticas (Callebat 1986194-198). Postular uma melhoria ulterior do sistema - e ainda mais sua generalização na navegação - procede como uma hipótese gratuita. O texto do Marciano tem, de fato, o mérito da clareza: exclui o uso de qualquer tipo de barquinha, ele foi de um princípio tão simples quanto a barquinha a nós usada na marinha dos tempos modernos.

\section{Ausência de cartas}

Não há nenhuma razão para ser surpreendido, que tanto a barquinha quanto as ferramentas de ponta, de cabo ou de rota, tenham significado somente na percepção cartográfica da navegação. Porém, as cartas, especificamente, parecem totalmente estranhas à prática da navegação antiga.

A questão de cartas náuticas no Mundo Antigo foi objeto de posições muito firmes. Nenhum texto antigo permite, nem de longe, nem de perto, imaginar, mesmo que remotamente, sua existência. Infelizmente, uma vez que, frente às nossas práticas contemporâneas, parece ser natural a presença de um objeto, é àqueles que contestam a sua existência, há dois mil anos, que é solicitado a entregar a impossível prova de sua ausência. Pode-se, com efeito, demonstrar a existência de um objeto quando ele é descoberto. Sua ausência sempre deixa margem para dúvidas, mas na melhor das hipóteses, podemos esperar demonstrar a improbabilidade de sua presença no contexto de práticas e saberes conhecidos.

Os defensores de cartas antigas são poucos (Uhden 1935 Uggeri 1998) e concluem à sua necessária existência se fundando sobre um argumento reputado de evidência ou de verossimilhança: os antigos tiveram cartas náuticas, porque eles não poderiam não tê-las, a navegação sem mapas seria impossível. Tanto eles não podiam não tê-lo quanto possuíam informações necessárias para a preparação de cartas náuticas, do tipo daquelas que conhecemos para o período medieval: eles sabiam fazer mapas - não se diz precisamente quais - e eles conheciam a rosa dos ventos - e dispunham, além disso, de uma abundante literatura da geografia marinha, que não mais que as distâncias marítimas que ela continha, dizse, não teria sentido sem mapas de onde foram tirados indubitavelmente, e sem os quais não se podia navegar. Enfim, a ideia de que o conhecimento da Idade Média pudesse derivar da Antiguidade não é estranha a esse 
raciocínio: se a Idade Média conheceu as cartas náuticas - e sabe-se que as conheceu - seria impensável que os tempos antigos não fossem o modelo.

Esta abordagem, que tem mais suposições, muitas vezes questionáveis, do que demonstrações, baseia-se em uma imagem muito simplista da relação entre a Idade Média e Antiguidade, ignora o papel essencial da bússola na fabricação e na utilização da carta náutica medieval, e se funda, em grande medida, em uma confusão entre os vários tipos de documentos que descrevem as costas. Hoje, tanto os historiadores do mundo medieval (Gautier-Dalché 1995, 42-43; 1997 IV 121-122) quanto os da Antiguidade (Counillon 2004, 29-31; 42) enfatizam as especificidades próprias das cartas náuticas, de portulanos e de périplos. Estes documentos, irredutíveis uns aos outros, não são necessariamente complementares, não respondem às mesmas perguntas e possuem cada qual uma forma de vida autônoma.

As pesquisas realizadas desde mais de um século sobre os geógrafos antigos conduzem-nos atribuir às distâncias tomadas em mar, uma origem sem relação com qualquer cartografia, explicitada pelo próprio Marciano de Heracleia, que será objeto de nosso Capítulo II. As distâncias têm sido de fato extrapoladas, a partir da duração de percursos, que não têm qualquer relação com qualquer mapa que seja, exceto claro, se eles foram solicitados a posteriori por geógrafos para construir a imagem do mundo. São fruto da experiência, e não dos mapas, como quando Estrabão (2.5.8) nos diz que "os marinheiros (dizem que) o trajeto mais longo de Celtique na Líbia, feito a partir do Golfo Galáctico é de 5000 estádios". Quando o grau de precisão é da ordem de dez estádios, não pode vir de uma carta escrita à mão, da qual as aproximações são conhecidas; quanto aos números arredondados aos milhares, quando eles não são tirados de tratados de geografia, remontam à sua fonte primária: os marinheiros.

A ausência de cartas náuticas antes do século XII é hoje admitida por todos os historiadores da navegação antiga (Pomey 1997, 32). A suposição formal mais convincente que tem sido proposta é a que se deve a Janni P. (1998), que une as conclusões historiadores do mundo medieval (Gautier-Dalché 1996; Campbell, 1987, 380-381). A ausência de mapas antigos pode ser deduzida a partir de sua ausência da lista de obras relativas à geografia das costas, que Estrabão (8.1.1) enumera escrupulosamente, mas também de sua ausência total no mundo bizantino e do surgimento no século XII de uma cartografia náutica inteiramente desligada de toda a tradição anterior, enraizada unicamente no universo do Ocidente medieval. Ele mostra, em seguida, que as práticas da navegação antigas sugerem a navegação sem mapas e recorda que, mesmo após a emergência das cartas náuticas, podese demonstrar que permanecem, até o século XVI, mais como uma curiosidade das pessoas em terra do que um instrumento normal Heródoto, Unifesp, Guarulhos, v.4, n.1 - 2019.1. p. 327-394

DOI: 10.34024/herodoto.2019.v4.10124 
navegação. Todos os textos, bastante circunstanciais, que relatam o savoirfaire do condutor em matéria de navegação, são unânimes em elogiar o seu conhecimento do céu e dos fenômenos, e a total ausência de instrumentação, de qualquer natureza. Se é sabido que a carta foi, aos olhos dos antigos, sempre um objeto falso que exige por parte do seu usuário um conhecimento que permita superar os erros descritos, não somente deveríamos encontrar esses itens no elogio à ciência dos pilotos, mas estaríamos no direito de interrogar sobre as razões da sua utilização. A experiência de gerações de marinheiros, e não a leitura das cartas, ensinava que a partir de tal lugar, tal relação com tal astro conduzia normalmente em direção a outro lugar.

A existência de portulanos é, no entanto, assegurada. Sob esta designação reducionista tendemos a agrupar todas as obras descritivas não cartográficas, que são o pingente marítimo das rotas terrestres. Em detalhe, a sua tipologia parece ter sido bastante variada, a julgar pelos seus títulos: na verdade, eles são chamados de "ports" - conhecidos apenas por sua menção em Estrabão (8.1.1) que pensava, sem dúvidas, no trabalho de Timóstenes -, périplo ou ainda estadiasmo, como vários opúsculos chegados até nós. No entanto, é muito difícil de perceber nos detalhes quais as especificidades de cada um destes tipos de documentos se, de fato, estes títulos guardam uma diferença de natureza fundamental. A verdadeira questão é saber quem foram os autores e os usuários. Sabemos que na Idade Média, portulanos e cartas náuticas se desenvolvem e se difundem mais entre os meios urbanos onde pensa-se o mar, do que junto aos que o vivem cotidianamente (Petti-Balbi 1996, 274).

A ideia de que trata-se de um estrito ornamento de nossas Instruções Náuticas foi objeto de sérios matizes (Prontera 1992). Tanto quanto podemos julgar, a partir da forma em que nos chegaram, por sua natureza, essas obras não eram mais o trabalho de pessoas do mar do que destinadas a pessoas do mar. Entre os seus autores, contamos, por exemplo, o médico Hermógenes de Esmirna, um personagem bastante em vista na intelectualidade do seu tempo, por ter tido as honras de cinco epigramas vingativos da Antologia Palatina (XI. 89; 114; 131; 190; 257), e que morreu no segundo século da nossa era. Seu epitáfio $(I G R I V .1445=$ CIGr 3311) deunos uma exaustiva biografia sua: 77 livros de medicina, mas também uma série de obras de erudição, as quais listamos aqui na ordem em que aparecem na inscrição, ou seja, dois livros sobre a história de Esmirna, dois outros dedicados respectivamente à sabedoria e à pátria de Homero, e dois ainda, dedicados às origens das cidades da Ásia, quatro à cidades da Europa, e um para as cidades localizadas nas ilhas, um estadiasmo da Ásia, um estadiasmo da Europa, dois livros de estratagemas e, finalmente, um 
quadro sinóptico de cronologias de Esmirna e de Roma.

Seu ilustre confrade Galeano de Pérgamo havia, igualmente, redigido um périplo e acabou cometendo, durante uma viagem a Roma, um erro de programação lamentável, resultante da falta de conhecimento dos lugares, e para evitar um erro destes a seus contemporâneos, "de modo que, qualquer um que como eu, venha a visitar Héphaïstias possa descobrir a localização da cidade, e, consequentemente, organizar seu itinerário." 16 Uma preocupação análoga parece ter incitado a redação de itinerário marítimo, encomandado por Crinágoras de Mitilene a seu amigo Menípio, quando aquele se preparava para fazer uma embaixada à Roma, por volta dos anos 26-25 da nossa era ${ }^{17}$. Tratava-se, sem dúvidas, de Menípio de Pérgamo ${ }^{18}$ que já tinha escrito o Périplo do Mar Interior, em três livros, e uma obra consagrada às navegações transversais. Marciano de Heracleia, seu abreviador, assim como Crinágoras, considera Menípio um "geógrafo", e o primeiro nos ensina que ele relacionava nestas obras, História e Geografia ${ }^{19}$. À esta lista podemos acrescentar incontáveis autores de périplos e relatos de viagens, conhecidos e anônimos, como Cleombrote de Esparta que, como nos relata Plutarco ${ }^{20}$, seu contemporâneo, tinha viajado muito e publicado uma relação de suas viagens, sem estar de forma alguma motivado pela emporia - o desejo de ficar rico no grande comércio marítimo -: sua investigação deveria servir de base à filosofia, cuja finalidade era a teologia. Acrescenta-se, para uma boa medida, a Périplo do Ponto Euxino, de Arriano de Nicomedia, que é, acima de tudo, uma carta erudita ao Imperador Adriano, em que a maior parte do vivido é minoritário, e as preocupações utilitárias mais que discretas. Mediremos então, a que ponto a literatura dos Périplos poderia ser justificada, sem vocação utilitária imediata para os marinheiros.

Está claro que uma série de autores de périplos, entre os quais, Arriano de Nicomédia, concebia este tipo de obra como uma contribuição de homem honesto para o conhecimento de seus contemporâneos e como dado a potenciais viajantes, mais do que como ferramentas práticas para o marinheiro, ou, mais amplamente, às pessoas do mar. Não podemos, naturalmente, excluir que algumas dessas obras tenham sido direcionadas ao uso prático, mas há que se reconhecer que, no estado da documentação, não podemos tão mais afirmá-lo.

O denominador comum destas diversas obras parece ter sido, pelo menos,

${ }^{16}$ De simplicium medicamentorum temperamentis, IX.1.2 = Kühn, XII, p. 173.

17 Epigr. 43 Rubensohn = Anthologie Palatine, IX. 559.

18 Müller 1855, CXXXV sq.

${ }^{19}$ Müller 1855, 566, § 3 .

$20410 \mathrm{~A}=$ Def. orac., 2.

Heródoto, Unifesp, Guarulhos, v.4, n.1 - 2019.1. p. 327-394

DOI: 10.34024/herodoto.2019.v4.10124 
o de incluir toponímias costeiras, distâncias, expressas em estádios (daí o termo estadiasmo) e os elementos da natureza ou a qualidade da ancoragem. Parece, no entanto, que algumas obras fizeram o inventário de particularidades que os aproximam do conteúdo das Instruções Náuticas ou dos Pilotos Costeiros. Há, de fato, aqui e ali, modo variável segundo essas fontes, informações que parecem terem sido emprestadas de tais obras: os perigos conhecidos, as conhecenças, as áreas de aproximação costeira, as características dos portos e ancoradouros, os cursos d'água, as orientações astronômicas.

O Estadiasmo do Grande Mar, um documento anônimo bastante mutilado, cuja erudição atribui-se ordinária, sem argumento decisivo, escrita no século III da era cristã, ocupa um lugar relativamente à parte na literatura antiga dos périplos, devido à abundância e à natureza dos detalhes práticos que ele contém. Esta é na verdade uma compilação de documentos de épocas díspares (Desanges 2004), que parece, no detalhe de seu conteúdo, tornar o texto mais próximo da estrutura do que poderia ter sido as obras de assistência à navegação costeira, dos quais jamais saberemos se foram destinados aos comandantes ou se tinham apenas recolhido os saberes. Um extrato deste livreto (opúsculo) relativo à costa entre o Golfo de Gabès e Bizerte nos dá uma ideia das informações que podem ser encontradas ali:

[113] De Thapsus à Leptiminus, há 170 estádios. A cidade é pequena. Há bancos de areia bem visíveis. A aproximação da cidade é um tanto difícil.

[114] De Leptis à Thermae há 60 estadios. É um vilarejo. Da mesma maneira, também há ali bancos de areia e a aproximação é dificultada.

[115] Desde Thermae, depois de 40 estádios de navegação estamos em vista de um cabo do qual se encontram duas ilhas equipadas de estacas. Tem um ancoradouro reformado.

[116] Do cabo, temos a vista da cidade de Adramytos (= Hadrumeto = Sousse), há 40 estádios de distância. Não tem porto.

[117] De Adramytos até Aspis «o escudo redondo » em grego = Clupea [mesmo sentido em latim] = Kelybia) há 500 estádios. É um cabo elevado e bem visível que tem a forma de um escudo redondo. Navegar na direção da Ursa até fazer ela aparecer à esquerda. Há, de fato sob a água inúmeros bancos de areia cortantes. Em seguida chegamos em vista de Aspis, e próximo dela, de Néapolis (Nabeul). Do golfo de Néapolis a Aspis há 200 estádios. É um lugar elevado e existe ali uma cidade. Tem um porto protegido a oeste, distante 10 estádios da cidade. 
[124] De Galabras a Cartago, existe 120 estádios. É uma cidade importante, que possui um porto. Há uma torre na cidade. Ancorar à direita ao abrigo do cais.

[125] De Cartago a Castra Cornelii, há 303 estádios. Há um porto de invernagem onde pode-se invernar grandes unidades.

[126] De Castra Cornelii a Útica, há 24 estádios (= 3 milles, n.d.T). Há uma cidade. Ela não tem porto mas um ancoradouro agitado. Ficar vigilante.

As únicas obras - se bem se tratassem de livros e não partes de livros relativos à navegação em alto mar foram os diaploï ou "travessias". Sabe-se deles, somente através de empréstimos de geógrafos antigos ou por alguns dados anexados ao Périplo do Pseudo-Skylax e definidos como diaploï. Trata-se, de fato, em ambos os casos, de simples distâncias entre dois pontos distantes, alguns dos quais foram talvez inicialmente acompanhados, em todo o caso, de informações relativas à direção do vento favorável.

Em última análise, com exceção das rotas e desembarques costeiros, que são sempre a parte mais perigosa para os marinheiros, os documentos de acompanhamento deveriam, na maioria das vezes, sumir para dar lugar ao conhecimento empírico. A ausência de cartas é, como tal, parte de um conjunto de práticas radicalmente opostas à nossa e que justifica a ausência de todas as nossas ferramentas navegação, todas as quais estão relacionadas com o primado do mapa. Na verdade, é de sua capacidade de navegar sem instrumentos, bem conhecidas para os povos do Oceano Pacífico, e constitutivas das práticas de navegação antiga e, com raras exceções, da navegação medieval no Mediterrâneo, que tiramos as principais razões para esta ausência.

\section{Navegação sem mapa nem instrumento}

Hoje, é difícil imaginar o que poderia ser uma navegação sem mapa ou instrumento, com marcações noturnas e diurnas das costas bastante desiguais, de acordo com os períodos, mas, provavelmente, muito medíocre para a era grega, à qual remontam a maioria das fontes utilizadas pelos geógrafos antigos. Temos de fazer um enorme esforço de abstração para escapar do modelo de navegação matemática que pouco a pouco se 
impôs nos tempos modernos, em benefício de uma abordagem, não menos técnica, mas infinitamente mais empírica (Pomey 1997, 32-34).

Em nossa prática, a rota é primeiramente uma ideia abstrata, de essência cartográfica, que preexiste à sua implementação. $\mathrm{O}$ bom navegador, para nós, é aquele que saberá associar vários parâmetros codificados à rota teórica traçada no mapa, para fazer corresponder o melhor possível a rota real com essa ideia de rota. Estamos no âmbito do tecnicismo matemático crescente que caracteriza a navegação moderna, e que nasce precisamente no século XII com a carta náutica do tipo medieval e com os primeiros cartógrafos profissionais.

Para entender a navegação antiga, é necessário inverter a ordem dos dados, e considerar que, ao contrário, é o conhecimento prévio das possíveis rotas para chegar de um ponto A a um ponto B em certas condições de vento, isto é, um conjunto de conhecimentos empíricos acumulados pela aprendizagem de gerações de práticas rotineiras, que estabelece a rota e sua escolha.

Dito isso, a navegação de um ponto a outro supõe, não menos nessas condições, saber onde se está, para saber que direção tomar para chegar a um ponto desejado, e isto em condições fixadas pelas limitaçoes do vento e das correntes. No mar, durante o dia, exceto nos dias de nevoeiro, a operação normalmente não é o maior problema para o início de uma viagem, de modo geral, em vista de uma costa conhecida com pontos de referência conhecidos. À noite ou em alto mar, a consciência de onde se está, no entanto, é somente aproximada: ela consiste em saber que depois de tanto tempo navegando em determinadas condições e numa direção estipulada, deve-se estimar logicamente estar em tal distância ou a tal determinado tempo de percurso de tal (tais) outro(s) lugar(es) situado(s) em tal(ais) outra(s) direção(ões). É o fruto da experiência adquirida por gerações de marinheiros que são transmitidas de taverna em taverna, de lado a lado, de experiência em experiência, e de geração em geração, um patrimônio da memória espacial que é também uma memória do espaçotempo. No espaço reduzido do Mar Mediterrâneo, não se pode sair de uma bacia sem passar por um reduzido número de lugares determinados, raramente situados a mais de quatro dias de navegação uns dos outros, o inventário das possibilidades é sempre relativamente limitado. O piloto do navio de Paulo (Act. Apost., 27. 13-17), sabe, por exemplo, que a rajada de vento nordeste à qual ele se submete o levará inelutavelmente à grande Sirte, caso ele não consiga modificar a direção do navio. Mais que a fuga na cama do vento, sinônimo de naufrágio em Sirte, ele opta então pela capa seca, sobre âncora flutuante, que $\mathrm{o}$ faz normalmente derivar perpendicularmente no sentido do vento, numa direção o navio tem água

Heródoto, Unifesp, Guarulhos, v.4, n.1 - 2019.1. p. 327-394

DOI: 10.34024/herodoto.2019.v4.10124 
a correr se nada diminua o ritmo de sua derivação, o que ele faz docilmente com tela seca até Malta.

Este texto fundamental para a história de navegação pode ser comparado a outro texto, de algumas décadas antes, para o qual P. Janni (1998, 49-51), com razão, chamou atenção, porque descreve o princípio da navegação sem instrumentos. Ele foi retirado de um poema épico, a Farsália, no qual Lucano (8.167- 186) mostra mais uma vez o interesse muitas vezes um pouco pedante, e nem sempre infalível, que ele compartilhava com seu tio Sêneca, pelos fenômenos celestes, falando através da boca um controlador de navio.

Ao pôr do sol, Pompeu, o Grande, vencido, parte de Mytilène sem um destino preciso. À noite "ele pergunta ao condutor do navio sobre todas as estrelas, como ele reconhece as terras, que medidas no céu lhe permitiam cortar as ondas, com a ajuda de qual estrela ela podia ver a Síria ou que fogo brilhante na carruagem o poderia conduzir à Líbia. Ao ouvir estas palavras, o sábio observador do silencioso Olimpo responde: "Todos aqueles astros que realizam sua revolução para baixo no céu estrelado e que, sobre esta abóbada que nunca permanece em lugar, enganam os pobres marinheiros, não são os que seguimos; mas o eixo que não se mergulha nas ondas e não se deita nunca, que faz resplendir a dupla Arctos, é ele que dirige os nossos navios. Enquanto ele se apruamar no pico da minhas vergas, olhamos o Bósforo e o Mar Negro, que mergulham nas margens da Cítia. Que o Arctophylax descenda da cabeça de mastro e que Cynosura (Ursa Menor) se incline para a superfície do mar, é aos portos da Síria que tornar-se-á o navio. Seguidamente apresenta-se Canopus, que se agrada vaguear no céu austral. É uma estrela que teme Boreas; avança guardando-a também à esquerda para além de Pharos: o navio tocará a grande Sirte no meio das ondas. Mas para qual lado comanda você que eu estenda a vela, que eu vire agora meus escotos? »

A sequência do texto descreve um muito belo viramento de bordo e as novas configurações do cordame, que o acompanham, para ir na direção desejada. 


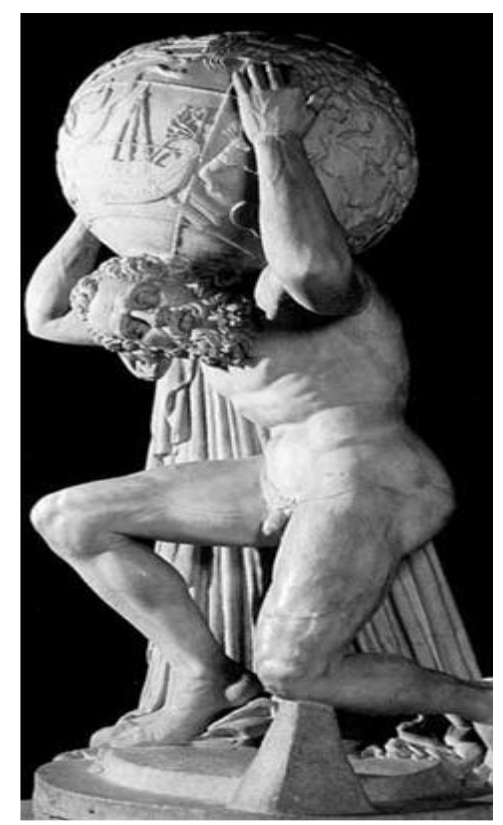

Fig. 19. O globo de Atlas Farnèse. Este globo figura a imagem das constelações sobre a sphère des fixes, o céu esférico dos Antigos, no qual as constelações são movidas por um movimento regular. As constelações são aqui representadas vistas do exterior e não do interior, como seria conveniente a um observador terrestre situado no centro desta esfera. Esta é uma imagem de uma das esferas utilizadas para ilustrar o céu. Segundo uma recente hipótese, as posições retidas pelas constelações seriam derivadas de um catálogo de Hiparco.

Vê-se que a navegação noturna, pelo menos, aquela descrita por Lucano, baseia-se, na realidade, em uma leitura relativamente elementar do céu. Os antigos imaginavam o céu como uma esfera sólida, chamada de "Esfera dos Fixos", no qual as constelações são animadas por um movimento de rotação regular fixo em torno de um eixo, cuja extremidade setentrional é dada pelas Ursas (movimento aparente, na realidade produzido pela rotação da terra). A Terra, imóvel, ocupa o centro desta esfera. Entre a Terra e a esfera dos fixos, as órbitas dos planetas são regidas por um movimento próprio. No movimento de rotação do céu, uma metade do céu, que varia com a latitude, e limitada por um círculo chamado "horizonte", permanece sempre invisível. 


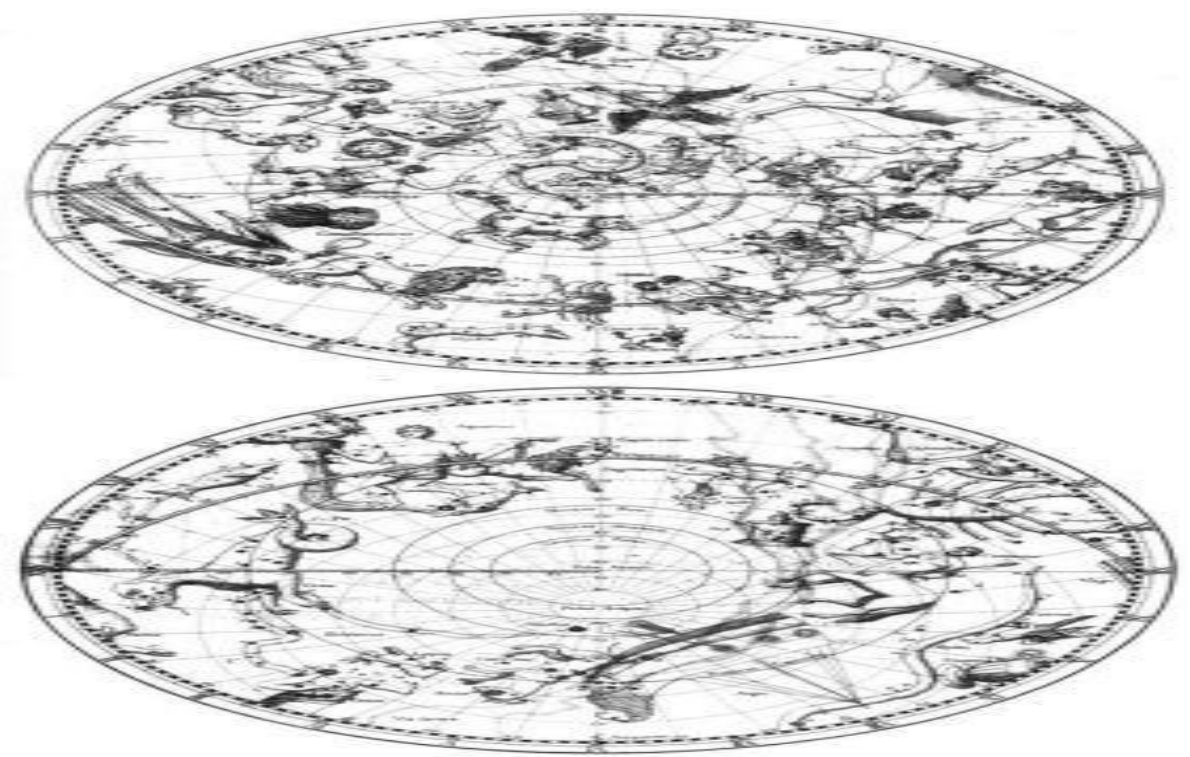

Fig. 20. Os dois hemisférios de Híparco: 1 - Hemisfério Boreal; 2 - Hemisfério Austral

O piloto começa por explicar que a maioria das constelações deve ser negligenciada na arte da navegação: são aqueles cuja mobilidade não são referências relevantes. Ele retém as constelações circumpolares cujos movimentos são reduzidos em torno do eixo rotação aparente do céu: para o hemisfério austral21, são as duas Ursas (Arctos), em particular a pequena Ursa (Cynosura) e a estrela polar 22, que à época de Lucano, não materializava ainda exatamente o pólo; para o hemisfério austral ele evoca Canopus, na constelação Argo. Esta última estrela situada à $52^{\circ}$ de latitude no hemisfério austral torna-se visível no horizonte ao observador terrestre à partir de $38^{\circ}$ de latitude N. À 40 milhas náuticas ao norte de Alexandria, à $32^{\circ}$ de latitude norte, sobe apenas $6^{\circ}$ acima do horizonte. O uso de Canope para a navegação é limitada às partes mais meridionais da bacia do Mediterrâneo, onde a sua aparição permanece fugaz. Sua menção deve, provavelmente, ser agrupada entre os pedantismos caros à Lucano. $\mathrm{O}$ essencial para nosso argumento é que a Ursa e Canope dão aproximadamente a cardeal norte-sul que constitui a ossatura da navegação astronômica antiga.

As direções são obtidas através da comparação da posição relativa da Ursa em relação aos pontos "fixos" do condutor, incluindo um número de elementos de navio: seu alinhamento sobre a cabeça do mastro para um observador situado na popa, na posição ocupada pelo piloto, indicava uma

\footnotetext{
${ }^{21}$ Há aqui um erro do original, em francês, e na verdade é ao céu boreal que Arnaud se refere.

22 É, sem dúvida, ela que Lucano designa sob o nome de Arctophylax (o "guardião das Ursas"). Habitualmente, é um dos nomes de Boieiro [Bouvier], mas esse aqui não tendo nada a fazer nas constelações circumpolares, é provável que seja um erro de Lucano.
}

Heródoto, Unifesp, Guarulhos, v.4, n.1 - 2019.1. p. 327-394

DOI: 10.34024/herodoto.2019.v4.10124 
posição em direção ao norte. Quando a Ursa Menor, abaixava ainda do mastro em direção ao mar (às costas do condutor), o navio rumava para o sul. Além disso, o aparecimento de certas estrelas, como Canope, assinalava uma latitude particular e sua elevação, mesmo que aproximadamente, no horizonte dava uma noção da latitude: Canope, por exemplo, se eleva $1^{\circ}$ no horizonte a cada 60 milhas náuticas - um grau de latitude - percorrido em direção ao sul.

A navegação astral desse condutor se limita, essencialmente, à utilização de um ponto cardial que define quatro orientações principais. É exatamente o sistema de orientação o qual utiliza Ulisses quando deixa a Ilha de Calipso (Odisséia, V, 270-278). Se o poeta menciona igualmente as Plêiades e Pastor, é ainda a Ursa que predomina, com a recomendação feita à Ulisses de manter a Ursa à esquerda para chegar à Ítaca.

Durante o dia, as limitações dessa navegação são evidentes. Elas se ligam, primeiramente, como à noite, à claridade do céu. Enquanto se pode estimar a direção e a velocidade do navio, uma avaliação bastante aproximada de sua posição em comparação a outros pontos conhecidos permanece possível. Mas o céu vindo a cobrir, ou direção do vento tornar-se incoerente, permanece somente a dúvida. E muito mais que um ataque dos elementos contra o navio, contra o qual a equipe parecia bastante experiente, a tempestade é o que confunde o piloto e faz com que que não saibamos ou onde estamos ou para onde vamos (Petti Balbi - 1996, 276).

Podemos, no entanto, dificilmente imaginar as complexas evoluções em alto mar, por conta da impossibilidade de determinar com razoável precisão o lugar onde se está, a da incapacidade de poder calcular com precisão o curso e a distância percorrida. A ideia de mudanças abruptas de direção em alto mar, sem o auxílio de sinais visuais, é pouco provável. Pela mesma razão, o bordejamento, necessário para ir contra o vento, tecnicamente possível e bem documentado nas práticas de navegação antiga, não pode ser vislumbrado para longas travessias, fora da vista das costas, salvo se imaginar viramentos de bordos perfeitamente regulares, em ângulo e largura (o que supõe um instrumento de cálculo do tempo).

As direções intermediárias, mesmo estendidas a setores inteiros, deveriam ser muito difíceis de seguir. Já foi notado (Pomey 1997, 33) que Plínio, o Velho (HN, 1192.), considerava a rosa dos ventos de doze direções ${ }^{23}$ muito sutil, e logicamente considera-se que a rosa efetivamente utilizada se

${ }^{23}$ De 8 ou 12 direções, elas utilizavam geralmente nos dois casos, as mesmas denominações, cf. Rehm 1916, 3sq; Masseling 1956; Kaibel 1885; Steinmetz 1907; Schmekel 1914, 215-245.

Heródoto, Unifesp, Guarulhos, v.4, n.1 - 2019.1. p. 327-394

DOI: 10.34024/herodoto.2019.v4.10124 
limitava à oito direções. Agatemero (2,6-7 Müller, 1861, 472-3) põe em principio a rosa dos ventos de 8 direções e junta a ela, por memória somente, a rosa de 12 direções, atribuindo-a a Timóstenes, o que é suficiente para demonstrar a característica tardia da introdução de um dispositivo que não foi mais que objeto de curiosidade, desprovido de real significação, na ausência de instrumentos naturais de orientação tão finos. Com a rosa de oito direções, cada orientação ocupa um setor de $45^{\circ}$, mas essas áreas se reduzem a $30^{\circ}$ na rosa de doze direções. Sem instrumentos, a manutenção de um curso fora da vista da costa e embasado unicamente nas estrelas ou no sol, sem se desviar mais de $22^{\circ}$ da rota ideal, representa em si uma performance. Fazê-lo sem se desviar-se mais do que $15^{\circ}$, como supõe a referência à rosa de 12 direções, aparenta-se prodigioso.

É certamente inegável que as rosas dos ventos, mesmo complexas, que os autores clássicos nos transmitiram, alimentaram-se da experiência dos marinheiros, e que os nomes de vários dos ventos que são mencionados como o lapyx ou o Africus, lembram que foram eles que conduziram os marinheiros desde a zona da qual portavam os nomes (Japigia ${ }^{24}$, África) até o centro teórico da rosa (Prontera 1996). Mas, se prestarmos atenção aos ventos mencionados por antigos geógrafos, quando queriam situar duas localizações, uma em relação à outra, e com base não em um cálculo teórico, mas sim na prática da navegação e no conhecimento da orientação dos ventos, que rumam de um ponto para o outro, somos imediatamente atingidos pelo fato de que, embora a sua rosa de referência teórica compreenda geralmente 12 direções, ela é reduzida nesses casos precisos, normalmente, na melhor das hipóteses, a 8 direções e, ás vezes a 4 direções: assim, considera Estrabão que o vento que vai de Rodes à Alexandria é um vento norte, enquanto a direção real deste vento é geralmente o noroeste, e Rodes está em uma direção norte, quarto noroeste a noroeste em relação à Alexandria. Os nomes de alguns ventos intermediários, tais como Leuconotos, que aparece apenas uma vez, em Erastóstenes (Estrabão, Geografia, 1.2.21 e 03.17.21), precisamente originário dessa região, para caracterizar a orientação respectiva da Cirenaica (Apolônia, porto de Cirene) e da extremidade sudoeste da ilha de Creta (cabo Criu Métopon), ou ainda o Euroaquilão, que atinge o navio de Paulo ao longo das costas da ilha de Creta (Act. Apost., 17.13 sq.), têm provavelmente uma origem local, e representam, sem dúvida, mais um conhecimento empírico do que um sistema de referência abstrato e perene.

\footnotetext{
${ }^{24}$ Apúlia

Heródoto, Unifesp, Guarulhos, v.4, n.1 - 2019.1. p. 327-394

DOI: 10.34024/herodoto.2019.v4.10124
} 


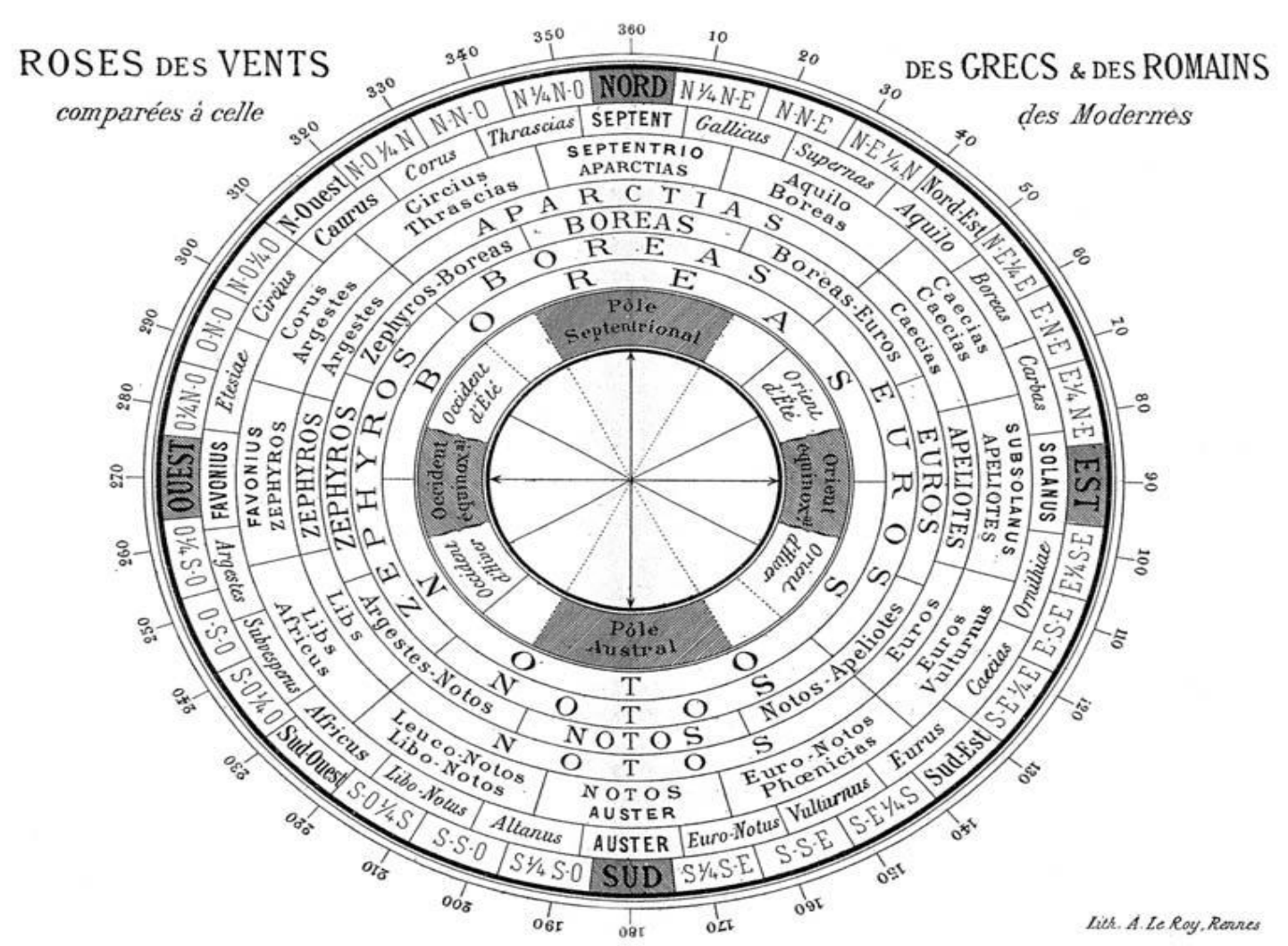

Fig. 21. A rosa dos ventos dos Antigos de J. Vars. Nota-se a diversidade de sistemas, cuja complexidade foi crescente. As rosas de referência da navegação são as mais simples, de 4 e 8 direções.

Tudo nos leva a crer que, como sugerem Lucano e Homero, a rosa empírica do navegante deveria ser limitada à quatro direções da rosa cardial, estendidas em uma vasta área de incerteza, de uma parte a outra da linha cardeal. A razão pede a considerarmos que, portanto, a navegação astral sumária dos Antigos, sempre tributária de um céu claro, garantia, pelo menos, quatro direções cardeais simples, e, mais aproximadamente, algumas direções intermediárias, sejam aquelas fornecidas por alguns amanheceres e entardeceres estelares (variáveis de acordo com tempo), seja, sob certas mareações, alinhar a Ursa na ponta do estaleiro poderia permitir manter um meio termo entre os dois pontos cardeal aproximados. A rosa de 8 direções constituía um ganho teórico, provavelmente pouco utilizado na prática para a navegação. Suponhamos, de fato, que, se, à noite, e em tempo claro, dispomos de um norte aproximadamente certo, a despeito de não ser absolutamente preciso, durante o dia, o único ponto de referência é um móvel, o sol, cujos amanheceres e entardeceres aparentes variam conforme a estação, e que indica uma direção cardeal somente ao zênite, ao meio-dia. As ordens de aproximação diurnas eram, portanto, ainda mais importantes que aquelas que poderíamos registrar à noite.

É claro que uma orientação tão aproximativa, aceitável para os trajetos Heródoto, Unifesp, Guarulhos, v.4, n.1 - 2019.1. p. 327-394

DOI: 10.34024/herodoto.2019.v4.10124 
relativamente curtos, rapidamente transmitida por uma navegação à vista, no entanto, não garante o rigor da orientação satisfatória para as travessias de muitos dias, praticadas fora da vista das costas e de grandes distâncias. Essa situação põe um problema de grandeza na hipótese segundo à qual se admite que a navegação em alto mar foi a prática comum de navegação. Ela praticamente exclui as mudanças de orientação importantes e voluntárias na ausência de pistas visuais claras que somente as costas oferecem ao marinheiro.

A resposta a esta objeção, que não se pode negligenciar, deve ser procurada em duas direções. A primeira consiste em buscar outros sistemas de navegação. A segunda é se interrogar acerca da pertinência do modelo de navegação em alto mar que é mais recorrentemente utilizado como referência pelos eruditos modernos.

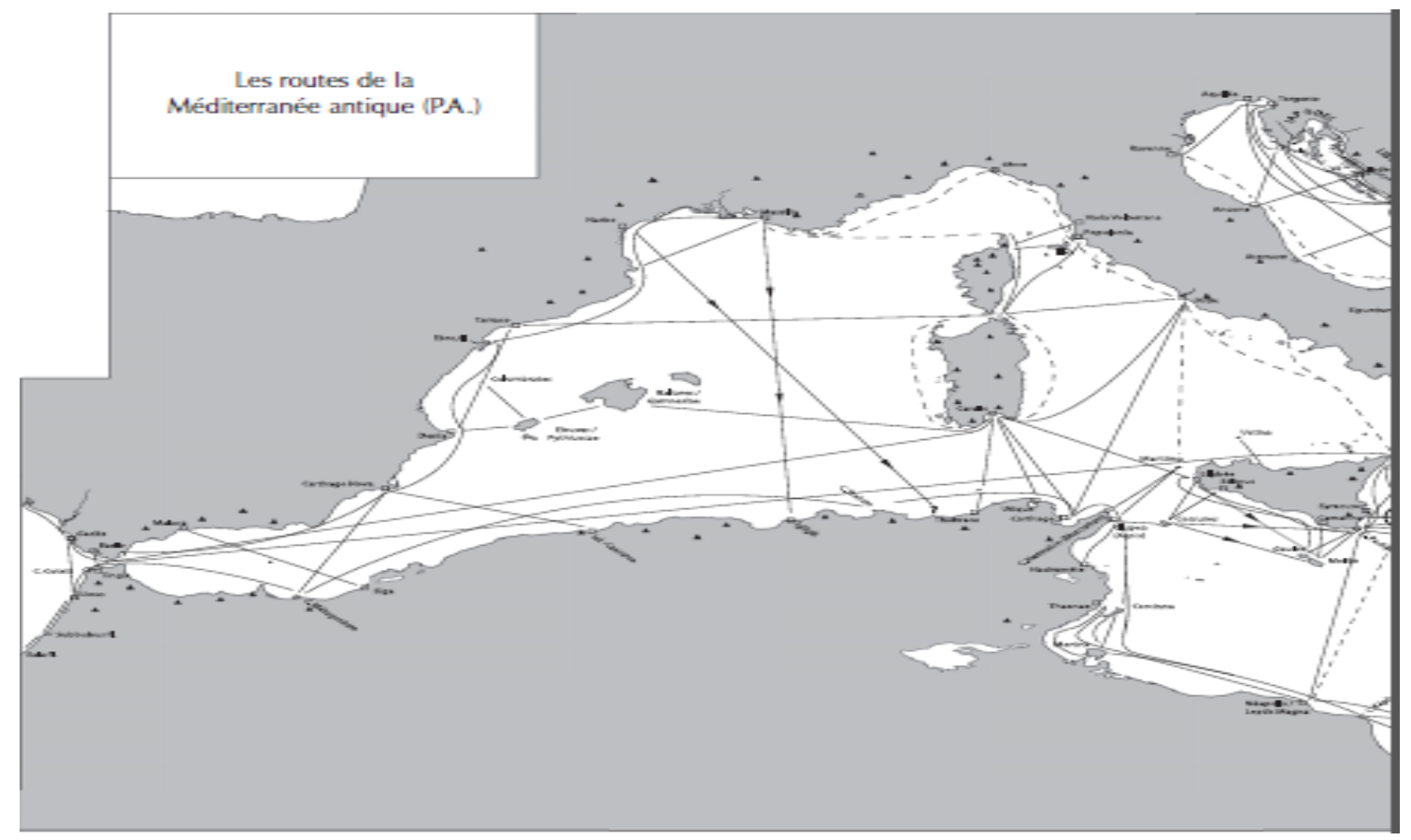




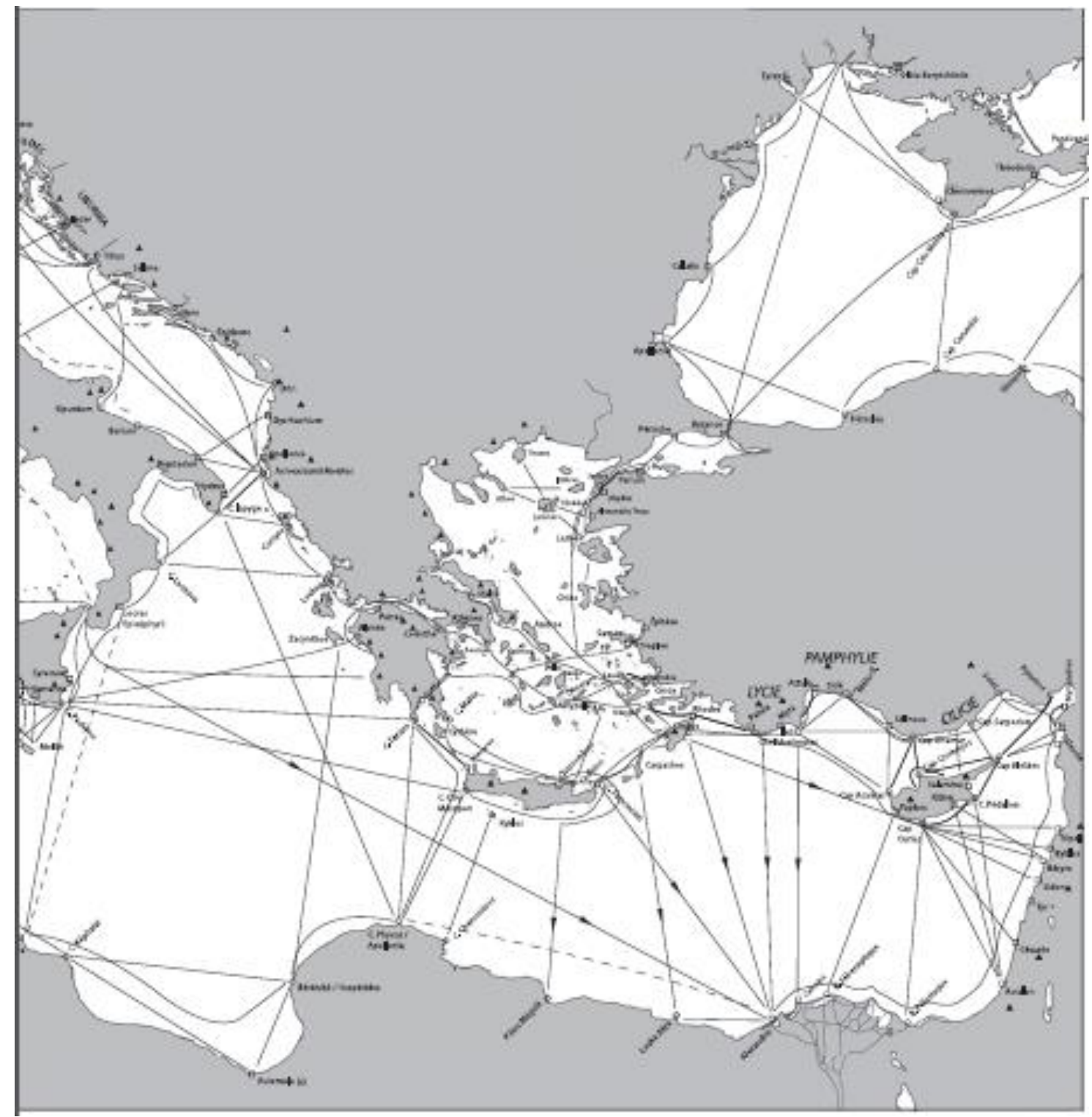

Fig. 22. As setas indicam a direção de navegação quando a rota é praticável apenas em um dos sentidos. Seremos sensíveis a segmentação das rotas. Não há praticamente nenhuma rota em alto mar direta a uma grande distância. Os itinerários à grande distância são produzidos pelo ajuntamento dos segmentos da rota.

A reflexão moderna sobre a navegação astronômica (celestial) dos Antigos procede, sem dúvida, do mesmo anacronismo fundamental que admite que a ideia cartográfica de mapear uma rota preexiste necessariamente à sua execução através de sistemas de referência com uma precisão suficiente. Ela postula que, para traçar a rota, eu saiba quais são as posições absolutas do ponto de partida e de chegada, e qual é a orientação eu deva dar ao navio, e que eu esteja em situação de imprimir a orientação desejada. A narrativa da navegação de Paulo (Act. Apost., 26-27), a navegação de Isis (Lucien, Nav. 7-9), ou ainda a passagem de Lucano, sobre a qual nós acabamos de passar, mostram claramente que na condição de não se exigir um grau de precisão extremo, os pilotos da Antiguidade sabiam Heródoto, Unifesp, Guarulhos, v.4, n.1 - 2019.1. p. 327-394 
aproximadamente, dada a passagem do tempo transcorrida em uma direção determinada, a partir de um lugar determinado, para quais regiões lhes levariam tal ponto cardeal, e não tal outro, e quais eram as posições relativas dos lugares. Isso torna extremamente difícil de explicar que as fontes antigas evocam rotas bem precisas que atingem invariavelmente a um número limitado de pontos, cuja menção é tão mais significativa que em regra geral, não se tratava de portos. Como explicar, por exemplo, que, saindo da Sicília, conseguíssemos chegar regularmente à boca de Alfeu (Philostrate, Vit. Apoll. Tyan 8,15; infra, Rota No. 47), já que os tempos de percursos registrados excluem itinerários de cabotagem, e que um erro de $20^{\circ}$, equivalente àquele que Estrabão é incapaz de medir entre Rhodes e Alexandria, ou aqueles encontrados nas orientações relativas da Sicília e do Peloponeso, seria suficiente para fazer o desembarque do navio em Cythère (Cítera) ou Kerkyra (Corfu)?

Sem dúvida, existia um meio infinitamente mais empírico, mais efetivo do que procurar uma orientação teórica, mas quase à prova de falhas, enquanto o vento permanecesse estável. É suficiente saber sob qual mareação, a partir de um determinado lugar e por um vento determinado, chega-se em outro local. É então, a rota percorrida, registrada na memória coletiva, e não a rota teórica, que define o caminho a seguir. A direção pode ser vantajosamente determinada pela mareação do navio, isto é, pela relação entre a sua direção e aquela de um vento determinado. Os autores antigos nos convidam a isso quando determinam a orientação respectiva de dois lugares não em relação a uma rosa dos ventos teórica, mas tomando o nome e a orientação de um vento, assim que a mareação, em ocorrência o vento de popa, que os leva, como vimos mais acima, a propósito da descrição das posições respectivas de Rodes e de Alexandria, de uma parte, e de Apolônia e do cabo Criu Métepon de outra.

Se observarmos as cartas que fomos capazes de desenhar das rotas de navegação em alto mar na Antiguidade, tanto no Mediterrâneo quanto no Atlântico, notamos que elas correspondem a duas mareações principais: a $90^{\circ}$ do vento ou vento posterior. Contanto que o vento permaneça estabelecido, o navio mantém seu curso. Este modo de navegação, que pode ser combinado com a orientação cardeal - em particular para controlar a estabilidade da orientação do vento - supõe ventos estabelecidos para a duração de um percurso. Assim, encontra-se mais frequentemente, em áreas onde os ventos são eram reputados a ter uma duração mais ou menos igual àquela do percurso. Era tão mais fácil de pôrse em ação desde que o navio estivesse equilibrado sob velas, qual fosse a mareação e que ele não demandasse uma compensação permanente do timoneiro para corrigir as inclinações contrárias do navio, e do qual vimos

Heródoto, Unifesp, Guarulhos, v.4, n.1 - 2019.1. p. 327-394

DOI: $10.34024 /$ herodoto.2019.v4.10124 
o desenvolvimento regular. Tudo nos leva a crer que os navios antigos foram capazes de manter, sem grande dificuldade, uma mareação constante a até pelo menos $90^{\circ}$ do vento.

Manter um curso, conservando uma mareação por vento estabelecido era, ao mesmo tempo, um método simples e adaptável às capacidades de manobra das embarcações antigas. Pode-se argumentar que ao número de desvantagens, certamente falta incluir a deriva: mínima ao vento em popa, descontando-se as correntes de superfícies mais significativas, contanto que o navio não surfasse pela onda, ela devia conduzir à uma diferença significativa entre a rota teórica e a rota real, quando navegava ao vento de través. Esta diferença poderia, de resto, explicar o descompasso registrado entre as orientações supostas pelos Antigos, baseando-se no curso que acreditavam seguir, e as orientações indicadas nos mapas modernos, que apontavam o curso realmente percorrido para a mesma relação (cf. infra, rotas n. 47-51). Mas nesta prática empírica, a deriva provavelmente não era um inconveniente, na medida em que fazia parte do contexto normal do percurso. Se os Antigos possuíssem os nossos mapas, e praticassem a navegação com nossos métodos, sua situação teria sido muito outra, mas dentro de um sistema inteiramente empírico e autorreferencial, podemos tomar o inconveniente como nulo. Pouco importava se os marinheiros antigos acreditassem seguir uma direção a oeste, enquanto a deriva conduzia-os a uma rota oeste/quarto-sudoeste, se ela os levasse onde eles sabiam que iriam chegar, porque a experiência lhes dizia que partindo com essa mareação, com esse vento, eles chegariam, invariavelmente, se o vento permanecesse estável, ao termo uma duração conhecida, à vista de uma costa conhecida, cujos detalhes permitiriam corrigir um erro mínimo. A experiência integrava a deriva à normalidade da rota vencida. Somos atingidos pela extrema lógica dos itinerários presentes em nossas fontes, ao olhar de dados meteorológicos, quer no Mediterrâneo, no Atlântico ou sobre a rota das Monções, as grandes travessias reproduzem algumas relações simples com ventos predominantes estabelecidos, que são aqueles procurados pela navegação em alto mar.

No pequeno universo que é o Mediterrâneo, a terra sempre visível não é tão onipresente quanto se possa pensar, mas em todas as áreas onde sopram ventos bem estabelecidos, continuava possível, a partir de um ponto determinado, em condições meteorológicas adequadas (vento estável, céu claro) e conhecidas, alcançar um outro ponto conhecido, seguindo uma direção simples garantida, seja por um corpo celeste, seja por uma mareação, e chegar, ao final de um período apreciável desde o início, em vista de uma conhecença, graças à qual seria possível corrigir visivelmente inevitáveis erros de navegação, por tê-los contidos dentro de

Heródoto, Unifesp, Guarulhos, v.4, n.1 - 2019.1. p. 327-394

DOI: $10.34024 /$ herodoto.2019.v4.10124 
uma margem razoável.

Em última análise, o conjunto dos dados naturais e técnicas definem apenas um quadro, e mesmo que coubesse ao marinheiro da Antiguidade praticar suas escolhas, cabe ao historiador, hoje, de definir os termos, pois nem condições naturais, nem o contexto tecnológico, por si só, poderia nos permitir de reconstruir o espaço-tempo da navegação antiga. 